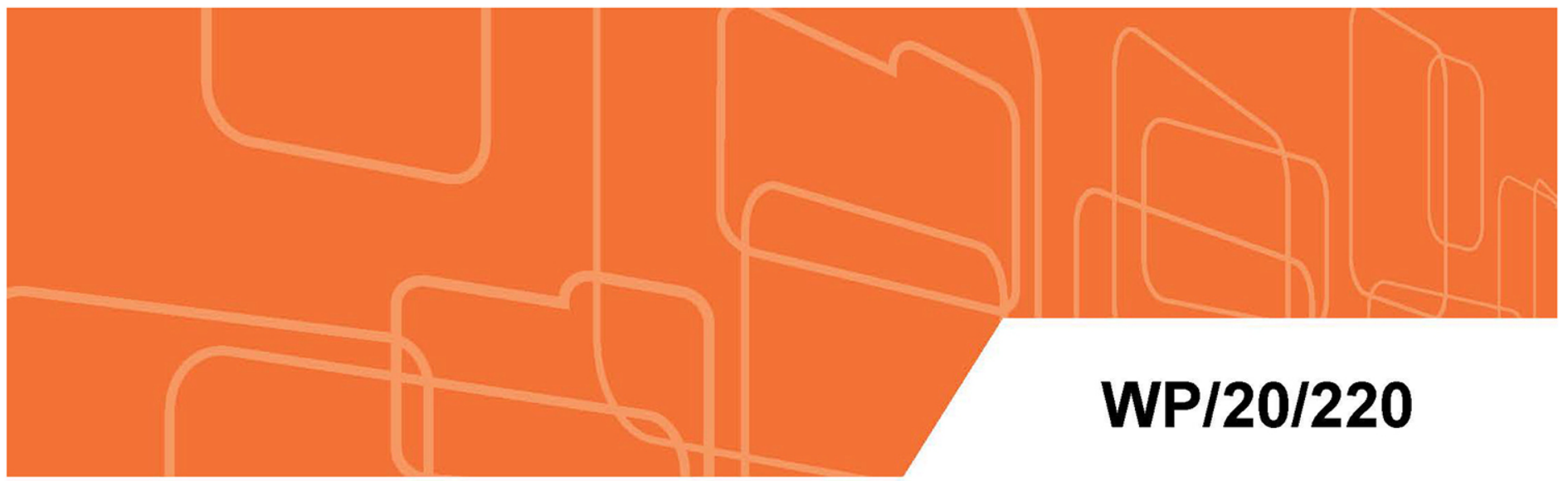

IMF Working Paper

\title{
The Sources of Fiscal Fluctuations
}

by Antoine Levy, Luca Antonio Ricci, Alejandro Mariano Werner

IMF Working Papers describe research in progress by the author(s) and are published to elicit comments and to encourage debate. The views expressed in IMF Working Papers are those of the author(s) and do not necessarily represent the views of the IMF, its Executive Board, or IMF management. 


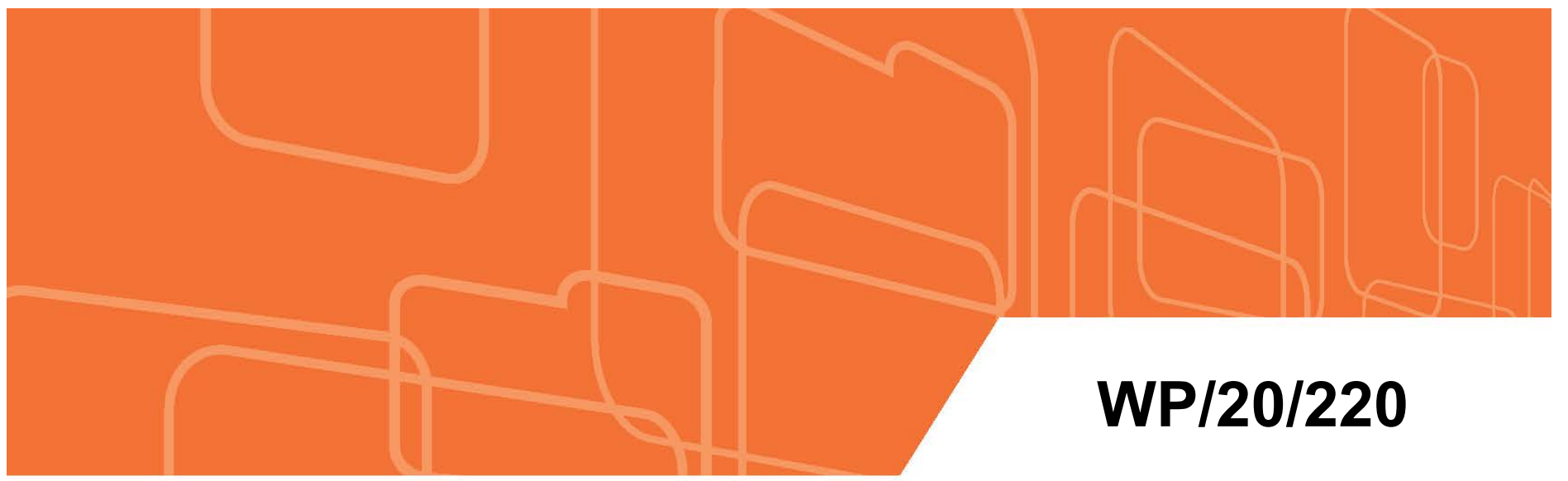

\section{IMF Working Paper}

\section{The Sources of Fiscal Fluctuations}

by Antoine Levy, Luca Antonio Ricci, Alejandro Mariano Werner

IMF Working Papers describe research in progress by the author(s) and are published to elicit comments and to encourage debate. The views expressed in IMF Working Papers are those of the author(s) and do not necessarily represent the views of the IMF, its Executive Board, or IMF management. 


\title{
IMF Working Paper
}

Western Hemisphere Department

The Sources of Fiscal Fluctuations

\section{Prepared by Antoine Levy ${ }^{1}$, Luca Antonio Ricci ${ }^{2}$, Alejandro Mariano Werner ${ }^{3}$}

October 2020

\section{IMF Working Papers describe research in progress by the author(s) and are published to} elicit comments and to encourage debate. The views expressed in IMF Working Papers are those of the author(s) and do not necessarily represent the views of the IMF, its Executive Board, or IMF management.

\begin{abstract}
This paper assesses the dynamic impact of global macroeconomic conditions, commodity price movements, shifts in portfolio preferences, and domestic shocks on fiscal outcomes-notably the budget deficit, its main components, and debt-across a wide range of countries. Heterogeneity is investigated across the level of development and other structural characteristics. Dynamics are explored via panel local projections, while robustness is assessed via dynamic panel and system GMM regressions. World growth, financial risk appetite, political events, and commodity export prices are key determinants of fiscal outcomes in EM, while domestic growth, commodity import prices, and banking crises appear to matter more in AE. Our estimates help quantify the amount of fiscal risk generated by various factors, and thus provide inputs for the design of potential insurance mechanisms or state-contingent debt instruments that could assist in smoothing fiscal fluctuations.
\end{abstract}

JEL Classification Numbers: E62; F41; H6; H87

Keywords: fiscal, deficit, debt, fluctuations, insurance, sovereign

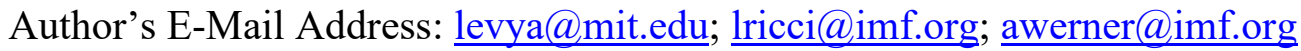

\footnotetext{
${ }^{1}$ IMF Western Hemisphere Department 2018 summer intern, and MIT PhD program.

${ }^{2}$ IMF Western Hemisphere Department, Division Chief.

${ }^{3}$ IMF Western Hemisphere Department, Director.
} 


\section{Contents}

I. INTRODUCTION —

A. Motivation

B. Literature Review

II. DATA AND METHODOLOGY _

A. Data

B. An Overview of Fiscal Volatility __ 1

C. Estimation Strategy __ $\underline{9}$

III. ESTIMATING THE FISCAL IMPACT OF EXOGENOUS SHOCKS _

A. The Dynamic Impact of Exogenous Shocks _ 10

IV. ESTIMATING THE IMPACT OF DOMESTIC GROWTH __

V. THE FISCAL COST OF SHOCKS: A DISCUSSION OF STATE-CONTINGENCY — $\underline{33}$

A. The Fiscal Cost of Shocks

B. State-Contingency Parameters for Public Debt

C. Variance Decomposition Exercise ___ 37

VI. CONCLUDING REMARKS

REFERENCES _

\section{ANNEXES}

I. DATA STATISTICS

II. DATA SOURCES _

III. LAC COUNTRIES

IV. PANEL REGRESSIONS FOR DIFFERENT COUNTRY GROUPINGS _

V. CORRELATION MATRIX OF SHOCKS _ $\underline{55}$

VI. FISCAL COST OF SHOCKS: REVENUE, EXPENDITURE __ $\underline{56}$

VII. VARIANCE DECOMPOSITION CHARTS __ $\underline{58}$ 


\section{INTRODUCTION ${ }^{4}$}

\section{A. Motivation}

Government fiscal balances vary significantly over time, especially in emerging economies, as a result of both global factors and a changing domestic economic environment. Such fiscal volatility makes it difficult to adequately manage public finances, often exposing governments to several risks, such as heightened borrowing costs when financing is needed, lack of fiscal space in crucial times, foregone investment opportunities with high social rates of return, or even costly defaults on debt obligations. Understanding fiscal fluctuations is important also because headline fiscal variables, such as the budget deficit and the debt level, constitute key policy indicators against which national governments are assessed by domestic and foreign investors, electorates, as well as multilateral institutions. And often such fiscal indicators constitute key metrics for budget rules imposing constraints on fiscal policy. However, there has been relatively limited empirical work aimed at quantifying the dynamic impact of exogenous sources of variation on a broad set of fiscal outcomes across country groups and their characteristics.

In this paper, we assess the short and medium-run impact on fiscal fluctuations, across a wide range of economies, resulting from key determinants, including: global growth, commodity prices, and world risk-appetite conditions, as well as political, financial and demographic shocks, and domestic growth surprises. The dynamic response of fiscal outcomes is particularly interesting, in light of the strong persistence of most fiscal and macroeconomic variables. We also explore how country characteristics, such as the level of developments or the commodity-exporter/importer status, drive heterogeneity in the impact of exogenous shocks. Fiscal outcomes are measured by the ratios of fiscal deficit, expenditure, revenue and gross debt to GDP; we also extend the analysis to international reserves to GDP ratio, as they are relevant to the broader discussion of smoothing shocks. Within the group of emerging and developing countries, we highlight the different response for the Latin American region.

The paper also aims at specifically quantifying the role of these shocks in driving fluctuations in fiscal outcomes. Indeed, we leverage on our results to estimate the fiscal costs associated with the shocks, by accounting for the impact and the respective volatility of the shock. Moreover, we calculate the contribution of the various shocks to the volatility of the fiscal balance, via a variance decomposition exercise in which we measure the share of forecast errors in fiscal fluctuations that can be explained by various exogenous shocks.

This work thus provides preliminary estimates of the extent to which fiscal risk could be insured against. This could be achieved either by designing synthetic assets which can hedge the loadings of fiscal fluctuations on exogenous global risk factors, or by employing existing financial instruments whose change in value can be expected to be related to exogenous macroeconomic shocks and thus help countries absorb the respective fiscal impact; such an

\footnotetext{
${ }^{4}$ The authors would like to thank Paola Cifuentes Henao for excellent research assistance as well as Francesco Grigoli, Metodij Hadzi-Vaskov, Roberto Piazza, Ippei Shibata, Susan Yang, Karim Youssef, and the participants in the WHD seminar for excellent comments.
} 
analysis is left for future work. Finally, by documenting the short and medium-run impact of domestic macroeconomic shocks, one can quantify the extent to which introducing statecontingent fiscal instruments (such as GDP-indexed bonds) could help smoothing the burden of fiscal fluctuations and insuring government liabilities from domestic shocks.

\section{B. Literature Review}

Existing analyses of the sources and insurability of fiscal volatility stem from three major strands of research: the rationale for fiscal smoothing; empirical measures of the sources of volatility; and the study of macroeconomic risk hedging and sovereign insurance. We present below a short review of the literature along these three dimensions.

\section{The theoretical tax smoothing literature}

A large literature studies the optimal path of government taxation and/or debt, for a given exogenous trajectory of spending or macroeconomic shocks. The government objective to smooth the distortionary costs of taxation over time and across states of the world (Barro, 1979), or to provide a constant stream of transfers to the private sector (Mendoza and Oviedo, 2006), affects the response of the fiscal deficit to temporary fluctuations in government receipts. When countries do not have access to state-contingent financing instruments, debt is likely to increase in times when revenues decline, and be used as a buffer against macroeconomic fluctuations (Marcet and Scott, 2009). If markets are complete and countries can fully insure their net wealth against macroeconomic drivers of their expenditure process, they should smooth distortionary taxation over time by making use of contingent financial instruments which lower the value of debt (or increase the value of assets) when future deficits are expected to rise (see Bohn, 1990). Building a debt structure that insulates the sovereign's wealth from macroeconomic fluctuations, either through maturity (Angeletos, 2002), currency choice, or contingency, would reduce the volatility of the taxation burden.

\section{The empirical "sources of volatility" literature}

Among studies analyzing sources of macroeconomic volatility (as in Raddatz, 2008; or Henzel and Rengel, 2017), some papers focused more specifically on determinants of fiscal outcomes, including: Agnello and Sousa (2009) for fiscal deficit volatility; Tujula and Wolswijk (2004) for budget deficits in OECD countries; and Lusinyan et al. (2009) for "surprises" in fiscal primary balances. Our paper also parallels recent work by Cerovic et al. (2018), which uses a large annual panel of cross-country variation, but focuses specifically on endogenous domestic predictors of tail events (fiscal crises), as opposed to also external drivers.

Other papers focus on the fiscal response to exogenous events, such as political transitions (Khandelwal and Roitman, 2013), natural disasters (Noy and Nualsri, 2011), conflicts, or financial crises (Laeven and Valencia, 2008), and to global macroeconomic factors, including growth in demand from trading partners, commodity price cycles (Aslam et al., 2016), or global financial and risk appetite conditions (Sahay et al, 2014). Fiscal fluctuations are partly the product of exogenous shocks directly affecting the tax base or expenditure needs, and partly the result of policy reactions to these shocks (McHugh, Petrova, and Baldacci, 2011). 
Distinguishing the direct role of economic conditions in public deficit variations has thus been a key focus of the empirical literature (see e.g. Blanchard, 1990).

Because of the history of major fiscal crises in Latin American countries, a significant share of the empirical literature has been devoted to this region specifically. The lack of domestic financial depth (Caballero, 2000), weaker policy institutions, and a reasonable degree of integration in world production and financial networks, expose the region to exogenous external shocks (terms-of-trade, capital flow reversals, monetary policy cycle, and trade partner's growth) more than the rest of the world (see Edwards, 2006; Raddatz, 2008; Klemm, 2014; BIS, 2016).

\section{The "macroeconomic hedging" and "sovereign insurance" literature}

Because public financing needs, liquidity constraints, and government balance sheets experience significant variations at high frequency, a growing body of macroeconomic and financial literature has been devoted to the potential for hedging such "macro risk". Such a literature focuses on the financial aspects of macroeconomic risk, estimating its statistical properties, measuring its determinants, and computing the loadings of specific variables (market returns, individual decisions, or macroeconomic outcomes) on measures of macro risk (see for example Caballero and Panageas, 2004; Ma and Valencia, 2018). Such a literature also provides an input to the design of financial assets that could offer insurance against macroeconomic shocks (Bali et al., 2014).

The study of "sovereign insurance", active both in academic research and in policy-oriented work (see IMF, 2017), revolves around the pros (such as reduced default risk, higher borrowing capacity, improved counter-cyclical fiscal space, and investor risk diversification) and cons of sovereign state-contingent debt instruments. A large body of research has been dedicated to the role of GDP-indexed debt in smoothing exogenous fiscal fluctuations by reducing the value of debt repayments in bad times (see for example Alfaro and Kanczuk, 2005; Barr, Bush, and Pienkowski, 2014; Borensztein and Mauro, 2002; Durdu, 2009; Hatchondo and Martinez 2012; Sandleris et al., 2011). Others have focused on estimating the potential for country risk pooling, either associated with aggregate GDP risk (Crucini, 1999; Callen et al., 2015) or specific sources of volatility such as natural disasters (Ghesquiere and Mahul, 2007).

\section{Our contribution}

Our paper provides contributions at the intersection of these various strands of literature. First, we identify and quantify the sources of fiscal risk in the short and medium-term for a broad set of advanced, emerging, and developing countries, with a specific focus on Latin America, thus providing a novel and more comprehensive quantification of the sources of volatility. Second, our results separately analyze both the relative contribution of the key subcomponents of the fiscal balance, expenditure and revenue, and of debt, thus informing the theoretical basis for tax smoothing and expenditure management. Third, when we focus on the effect of exogenous global factors on fiscal outcomes, we provide estimates for the sensitivity of fiscal variables to global macroeconomic risk, hence linking to the macro risk hedging literature. Finally, using external instruments, our quantification of the impact of GDP growth on debt paths at various horizons parameterizes the potential for state-contingency, which has the potential to 
dynamically insulate government liabilities from temporary macroeconomic shocks, as suggested by the sovereign insurance literature.

\section{DAta AND Methodology}

\section{A. Data}

Our research question is the quantitative dynamic relation between fiscal outcomes and several external and domestic macroeconomic factors. As fiscal outcomes we employ the ratios to GDP of overall fiscal deficit, expenditure, revenue, gross government debt, and net international reserves. The shocks are classified into thematic blocks, encompassing world macroeconomic fluctuations, trade-related variables, global financial conditions, banking crises, and other domestic shocks (including political developments, demographic shocks, and natural disasters). More precisely, these thematic blocks notably include:

1. a world macroeconomic block: comprised of world growth and world inflation, both weighted by purchasing power parity GDP (the second employed as a control in the linear projections panel estimation), the average level of the VIX volatility index over a year as an indicator of global risk appetite, and the average US 10-year yield as a proxy for global growth expectations.

2. a trade block: this includes the change in the goods and services terms of trade, the change in export and import commodity prices (calculated as a trade weighted average $)^{5}$, and the oil trade balance.

3. a "financial conditions" block: this includes global financial conditions as experienced by a country, which are proxied by the interaction of the VIX with financial creditor or debtor status defined as the value of net foreign assets to GDP, as well as domestic systemic banking crises.

4. an "other domestic shocks" block: this includes major political regime transition periods, detrended change in population, election years, a dummy for the occurrence of a natural disaster. These shocks are treated as exogenous in the sense that we assume conditional ignorability of the reverse causality from fiscal shocks towards such domestic shocks.

Our dataset is comprised of an unbalanced sample of a maximum of 194 countries, with yearly frequency spanning from 1970 to 2017. Most of the specifications focus on the post-1986 period, for which a more balanced coverage of the subcomponents of fiscal data is available. In most cases, the sample encompasses about 140 countries with about 25 years of data. ${ }^{6} \mathrm{We}$ exclude a few outlier observations where data reporting shows significant uncertainty that may drive the results: any year with annual GDP growth higher than 100 percent or inflation or

\footnotetext{
${ }^{5}$ See Gruss (2014).

${ }^{6}$ Some variables are only available after a certain date, like the VIX index (1986), elections (1995) or commodity terms-of-trade shocks (1980), while fiscal variables and domestic growth are available starting from 1970 for many countries in the sample; the full sample is therefore used for IV estimations focusing on domestic growth.
} 
exchange rate variation against the dollar larger than 200 percent; results are virtually unchanged when using the full sample without excluding outliers.

We explore three sub-samples: advanced economies (AE), emerging and developing countries (EMDC), and Latin American and Caribbean countries (LAC), on the basis of the IMF World Economic Outlook standard country groupings ${ }^{7}$. We also check how the role of some shocks differs across subsamples such as: external debtors/creditors (defined as having a negative/positive net foreign assets to GDP position), small versus large states (population larger than $1 \mathrm{mn}$ people), and more versus less open countries (defined as above and below the median trade openness in the period on average).

Most of the series are transformed to be stationary: real GDP, consumer price inflation, commodity price indices, exchange rates, terms-of-trade indices are all measured in yearly percentage changes; population, employment and life expectancy in deviations from countryspecific quadratic time trends; while expenditure, revenue, and fiscal balance measures are computed as percentage of GDP.

The Table in Annex I describes the main summary statistics for the key variables in our analysis, while Annex II describes the data sources. Generally, data for the headline deficit, expenditure and revenue are available for 195 countries and on average 35 years; fewer observations are available for other variables such as public debt ratios (176 countries for 36 years on average).

\section{B. An Overview of Fiscal Volatility}

When zooming in on the fiscal performance, we see that the average fiscal deficit in our sample stands at $3 \%$ of GDP, with a standard deviation of about $14 \%$; excluding the bottom and top $1 \%$ observations, the average deficit falls to $2.7 \%$ and the standard deviation to $5.5 \%$ (note that the results are robust to excluding these outliers). The within-country standard deviation stands at $12 \%$ (but only $4.6 \%$ excluding the top and bottom $1 \%$ observations). Expenditure appears slightly more volatile than revenue, a regularity that holds throughout our subsamples, both within and across countries: the within-country standard deviation of expenditure stands at $12.5 \%$, against a $7 \%$ within-country standard deviation of revenue to GDP.

The extend of the large share of within country variability within each group offers already an ideal of the potential for macro-insurance based on contracts related to global shocks (for small countries) to heterogenous response to global shocks across countries, and pooling domestic risk.

\footnotetext{
${ }^{7}$ Country groupings and classifications can be accessed at: https://www.imf.org/external/pubs/ft/weo/2018/01/weodata/groups.htm
} 


\begin{tabular}{|l|c|c|c|c|}
\hline \multicolumn{5}{|c|}{ Fiscal Deficit to GDP } \\
\hline \multicolumn{1}{|c|}{ Subsample } & Mean & Std. dev & $\begin{array}{c}\text { (Within-country) } \\
\text { std. dev }\end{array}$ & p [AR(1)] \\
\hline All economies & $-3.0 \%$ & $13.8 \%$ & $12 \%$ & 0.62 \\
\hline Advanced economies & $-1.7 \%$ & $4.9 \%$ & $3 \%$ & 0.75 \\
\hline EM and developing & $-3.3 \%$ & $15.4 \%$ & $13 \%$ & 0.62 \\
\hline LAC countries & $-3.0 \%$ & $4.9 \%$ & $4 \%$ & 0.76 \\
\hline Commodity exporters & $-3.2 \%$ & $23.7 \%$ & $20 \%$ & 0.63 \\
\hline
\end{tabular}

Deficits are slightly higher on average, and more volatile, in emerging and developing countries than in advanced economies, driven by the higher volatility of both expenditure and revenue. Fiscal balances tend to exhibit much higher volatility in commodity exporters than in the typical emerging and developing countries, while in LAC countries volatility is similar to the one of advanced economies.

We plot below the evolution of the median fiscal balance to GDP across various subsamples over time, showing a noticeable trend towards a long-term improvement in fiscal balances in in emerging and developing economies, particularly in LAC countries.

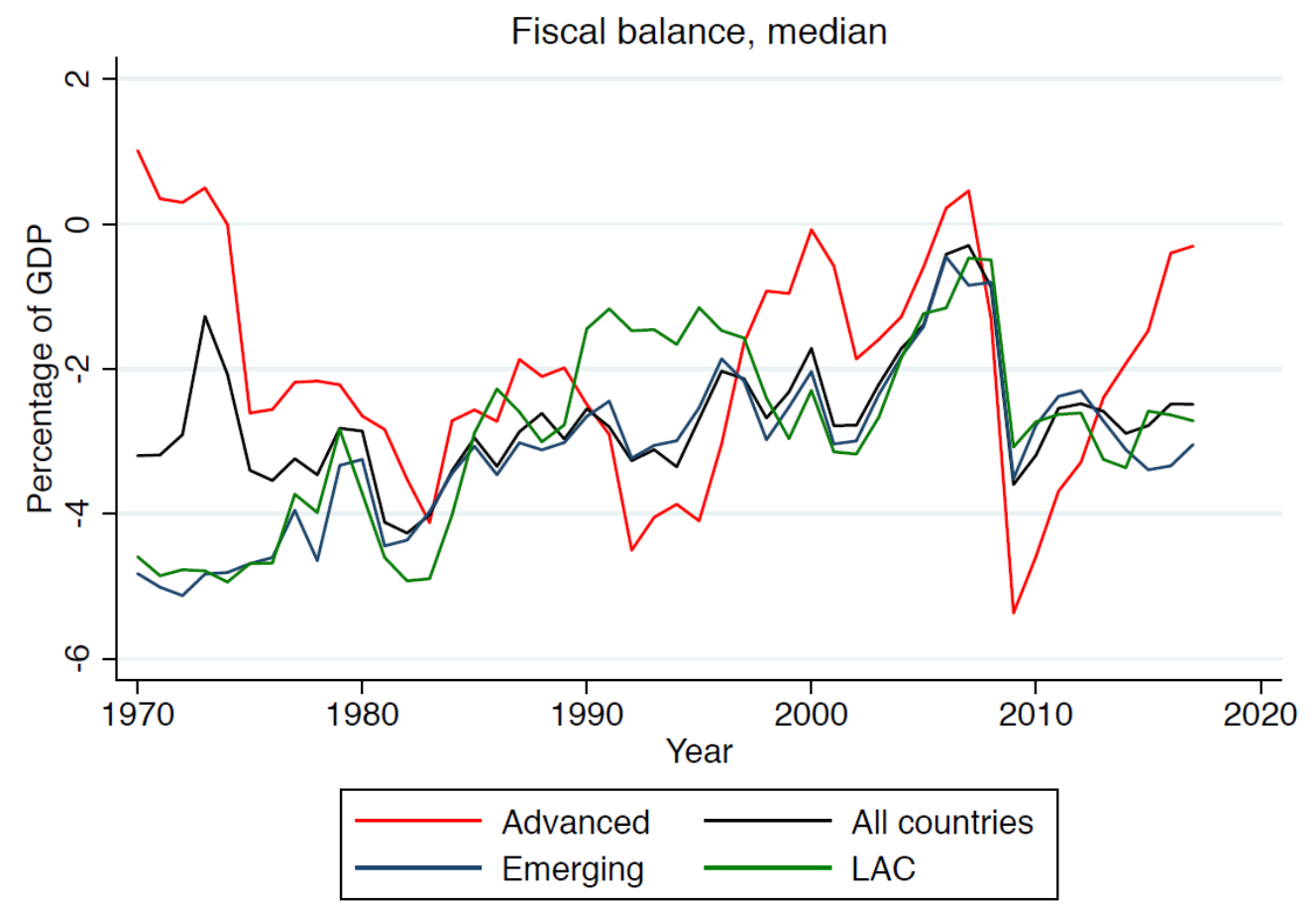


Focusing on Latin America and the Caribbean, a subsample of 32 countries with on average 40 years of data available for the fiscal balance, we notice that fiscal outcomes are volatile in the region, but not particularly so compared to other emerging and developing economies. The within-country standard deviation of the overall fiscal deficit is around $4.6 \%$ of GDP, with a mean value of a $3.1 \%$ of GDP deficit; the corresponding values for advanced economies are about $5 \%$ standard deviation and $1.7 \%$ of GDP deficit, while, for all emerging and developing economies, they are 15 and $3.4 \%$ deficit. In LAC countries, as in all subsamples, expenditure to GDP ratios are relatively more volatile than revenue to GDP, exhibiting a $6.4 \%$ withincountry standard deviation for expenditure against 5.2\% for revenue.

\section{Estimation Strategy}

We employ two main methodologies: local projection methods and panel fixed effect regressions. When studying of the effect of domestic growth, instrumental variables are used to account for potential endogeneity.

First, we employ the OLS Local Projection (LP) Method of Jorda (2005), which allows us to study the dynamic short-term and medium-term responses of fiscal outcomes to shocks across country groups. We focus on the response from the year of impact to the next 3 years (which is generally close to the timeframe of interest for most policymakers). The LP method accounts for non-linear response patterns over time, and enables us to consider the rich dynamics of our endogenous and explanatory measures by controlling for lags of the dependent and independent variables. This is important as some of the shocks may take time to propagate and affect fiscal outcomes. At the same time, the LP method permits some degree of differentiation in responses depending on structural characteristics, by allowing estimations across subsamples. It is also more robust to misspecifications than VAR modelling, since impulse response functions do not compound potential misspecifications as the projection horizon grows larger. Finally, inference is based on traditional dynamic panel OLS estimators' variance-covariance matrices, allowing us to visually plot confidence intervals for response functions that draw on standard robust covariance estimators for panel data. The local projection takes no stand on causal identification, beyond selection of controllable observables: therefore, causal interpretation of the time paths of outcome variable can only be readily assumed when studying plausibly exogenous regressors.

Second, we employ panel fixed-effects estimation, which allows to remove the systematic idiosyncratic component and study within-country variation. For robustness, we also use the generalized method of moments approach of Arellano and Bond to correct for the potential bias in the estimation of dynamic panel regressions with a lagged dependent variable.

These methodologies are first applied to the analysis of the exogenous shocks. These shocks are not likely to be affected by the fiscal balance of individual countries, which limits the risk of reverse causality. ${ }^{8}$ However, some exogenous shocks such as world growth or VIX are likely to affect domestic deficits largely through their effect on domestic growth. Hence, when trying

\footnotetext{
${ }^{8}$ These regressions are run excluding the US given the likely endogeneity in the determination of financial market conditions in the US.
} 
to measure the overall fiscal effect of such variables, one should not "hold domestic growth constant" by including domestic growth in the same regression, as this would bias our estimates of the "true" effect of the exogenous shocks.

Then, in order to analyze the impact of domestic real GDP growth on fiscal outcomes, separate regressions are run with instrumental variables applied to both methodologies (panel and local projections). Indeed, there is a second concern we are trying to address. Fiscal variables themselves may impact domestic growth, through the multiplier effect of domestic expenditure, or through the distortion of incentives and the wealth effects of taxation and debt. Therefore, when focusing in the second part of the analysis on the fiscal effect of domestic growth, we need address its endogeneity by instrumenting growth via plausibly exogenous predictors such as global dynamics to remove the likely endogeneity. We then use the estimated effect (via instrumental variables) of a 1 percent change in growth on debt to GDP ratio $h$ years ahead as inputs in quantifying the potential for state-contingency, suggesting the magnitude of required adjustments in debt value to neutralize growth-driven variations in liabilities.

\section{ESTIMATING THE FISCAL IMPACT OF EXOGENOUS SHOCKS}

\section{A. The Dynamic Impact of Exogenous Shocks}

We employ the LP method to regress the fiscal outcomes of interest at various lead horizons $y_{i t+h}$ on the plausibly exogenous variables of interest, adding controls and/or interactions to distinguish heterogeneous responses. We run the following set of fixed-effects panel regressions, for $h=(0,1, \ldots, H=4)$ :

$$
y_{i t+h}-y_{i t-1}=\alpha_{i}^{h}+A^{h}(L) \Delta y_{i, t-1}+\beta_{h}(L) D_{i t}+B^{h}(L) X_{i t}^{D}+\varepsilon_{i t, h}
$$

where $\Delta$ is the first-difference operator, $D$ is the (stationary) variable of interest, $X^{D}$ is a set of $D$-specific control variables, and $A^{h}(L), B^{h}(L), \beta_{h}(L)$ are 2-lags polynomials for each horizon of projection, and $i$ and $t$ are, respectively, country and year indices (with $\alpha^{h}{ }_{i}$ a country fixed-effect).

Our parameter of interest is $\beta_{h}(0)$, for $h=0,1, \ldots, H$ :

$$
\begin{array}{r}
\beta_{h}(0)=E\left(y_{i t+h} \mid D_{i t}=1, X_{i t, t-1, \ldots, k}^{D}, D_{i, t-1, \ldots, k}, y_{i, t-1, \ldots, k}\right) \\
-E\left(y_{i t+h} \mid D_{i t}=0, X_{i t, t-1, . ., k}^{D}, D_{i, t-1, \ldots, k}, y_{i, t-1, \ldots, k}\right)
\end{array}
$$

These local projections on external exogenous shocks are obtained without controlling for contemporary domestic growth, since we expect most of these shocks to propagate to fiscal outcomes also through their effect on the domestic business cycle. We do control, however, for domestic inflation and its lags, lags of (log) real GDP (hence for past growth), world inflation, as well as world growth (except when the shock of interest is likely to propagate through world growth, such as a VIX shock or a US interest rate shock). Additional controls may be appropriate for specific shocks and are mentioned in the respective sections discussing the results. We also control for 2 lags of the explanatory variable of interest, 2 lags of each control variable, and 2 lagged differences of the dependent variable, to account for flexible 
deterministic dynamics. In the following figures, darker and lighter confidence bands represent 90 percent and 95 percent confidence intervals, respectively, using standard errors robust to heteroskedasticity, and clustered at the country level. Since propagation mechanisms may differ across country groups or depending on various structural characteristics, we also compute local projection responses for various subsamples'. Key results for the Latin American region are presented in Annex III.

\section{The effect of global macroeconomic variables}

A world growth persistently affects fiscal outcomes, controlling for contemporaneous commodity prices. A 1 percentage point increase in PPP GDP weighted world growth is associated, for the average country and on the year of impact, with an improvement in the fiscal balance (by somewhat more than $1 / 2$ of a percentage point of GDP). Note that the regression controls for commodity prices, so these prices are not the channel of conduit for the effect of world growth on fiscal variables. The effect seems to operate mainly via higher revenue ratios in EMDC and via lower expenditure ratios in AE. The improvement in the fiscal balance is also more persistent in emerging economies, where it stands at around $0.3 \%$ of GDP even four years after the initial impact. The effect on expenditure to GDP ratios in advanced economies partly comes from a stronger "denominator" effect in $\mathrm{AE}$, as visible in the bottom right panel where the reaction of GDP to world growth is stronger in AE. This effect is likely to result from expenditure that is not indexed but budgeted in nominal terms, so that the expenditure ratio would tend to decline when the denominator rises. Moreover, AE tend to have higher expenditure to GDP ratios, which implies a stronger leverage for such an effect. It should be noted that the insignificant response of the revenue-to-GDP ratio in advanced countries is somewhat puzzling, given that income tax systems are generally progressive in such countries (thus a higher GDP growth should lead to higher average tax rates and an increase in the revenue-to-GDP ratio); this could be due to the simultaneous discretionary policy, such as procyclical tax cuts.

\footnotetext{
${ }^{9}$ A more comprehensive set of the results than those reported in graphical form in the paper are available upon request from the authors.
} 
Responses to 1 p.p. increase in world growth

Emerging and developing vs. Advanced
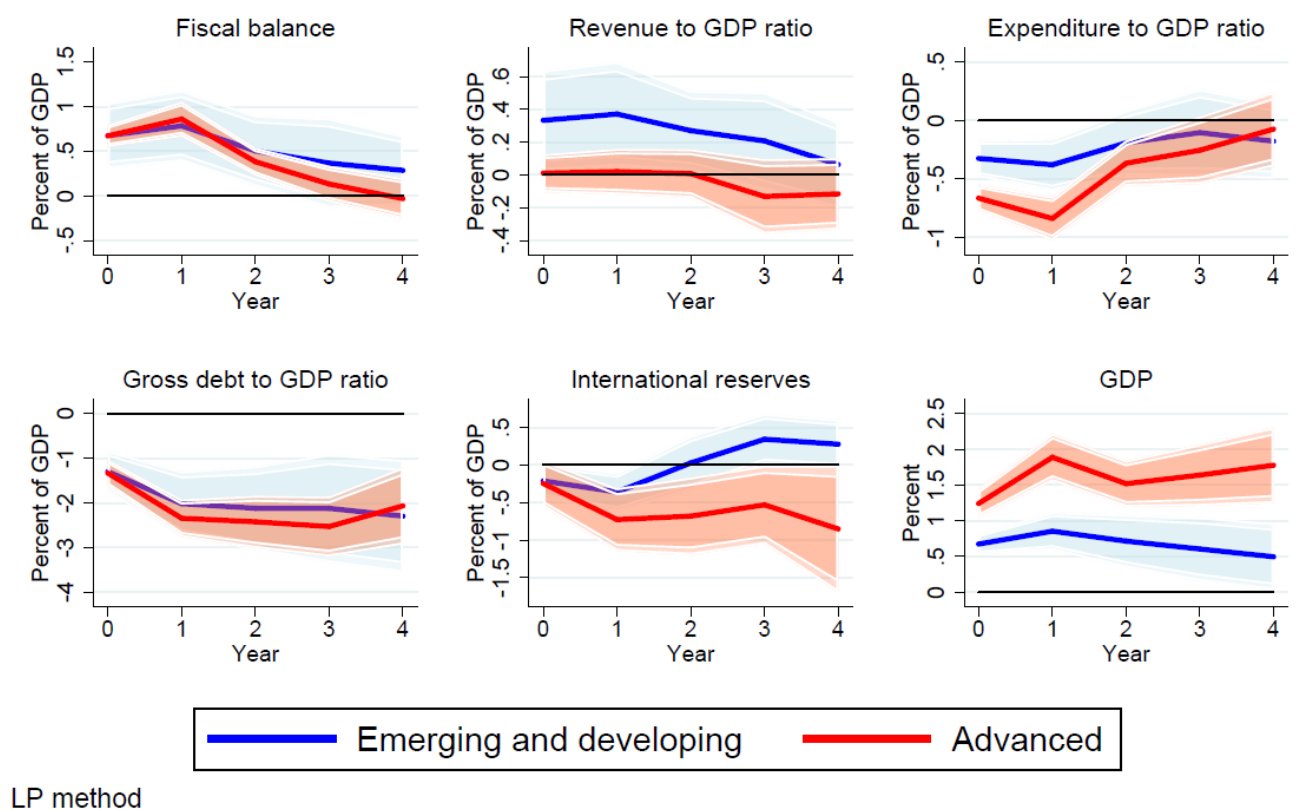

The effect of terms-of-trade variables

We compute the reaction of fiscal outcomes to a change in the goods terms-of-trade variable from the World Economic Outlook (results are robust also when using a "goods and services" measure). Following a one-standard-deviation terms-of-trade increase, the most notable effect is an increase in GDP, especially in EMDC. EMDC also experience a more positive effects on revenue and expenditure ratios than AE. The effect on the fiscal balance in EMDC is substantial initially (about $1 / 2$ percent of GDP), but eventually the increase in expenditure ratios eats the fiscal space created by the increase in revenues ratios. In advanced economies, the moderate positive effect on the fiscal balance is mainly driven by the moderate positive effect on GDP which lowers the expenditure ratio (at the same time offsets the revenue increase thus entailing a flat reaction of the revenue ratio; it should also be noted that terms of trade do not necessarily generate more revenues in advanced economies, as they instead do more frequently in EMDC, given that in the latter group of countries terms of trade fluctuations are often driven by commodity export prices). The stronger GDP effect in EMDC implies a stronger reduction in debt ratios, despite a similar overall effect of fiscal balance. Reserves increase mainly for $\mathrm{EMDC}$ and not for $\mathrm{AE}$. 


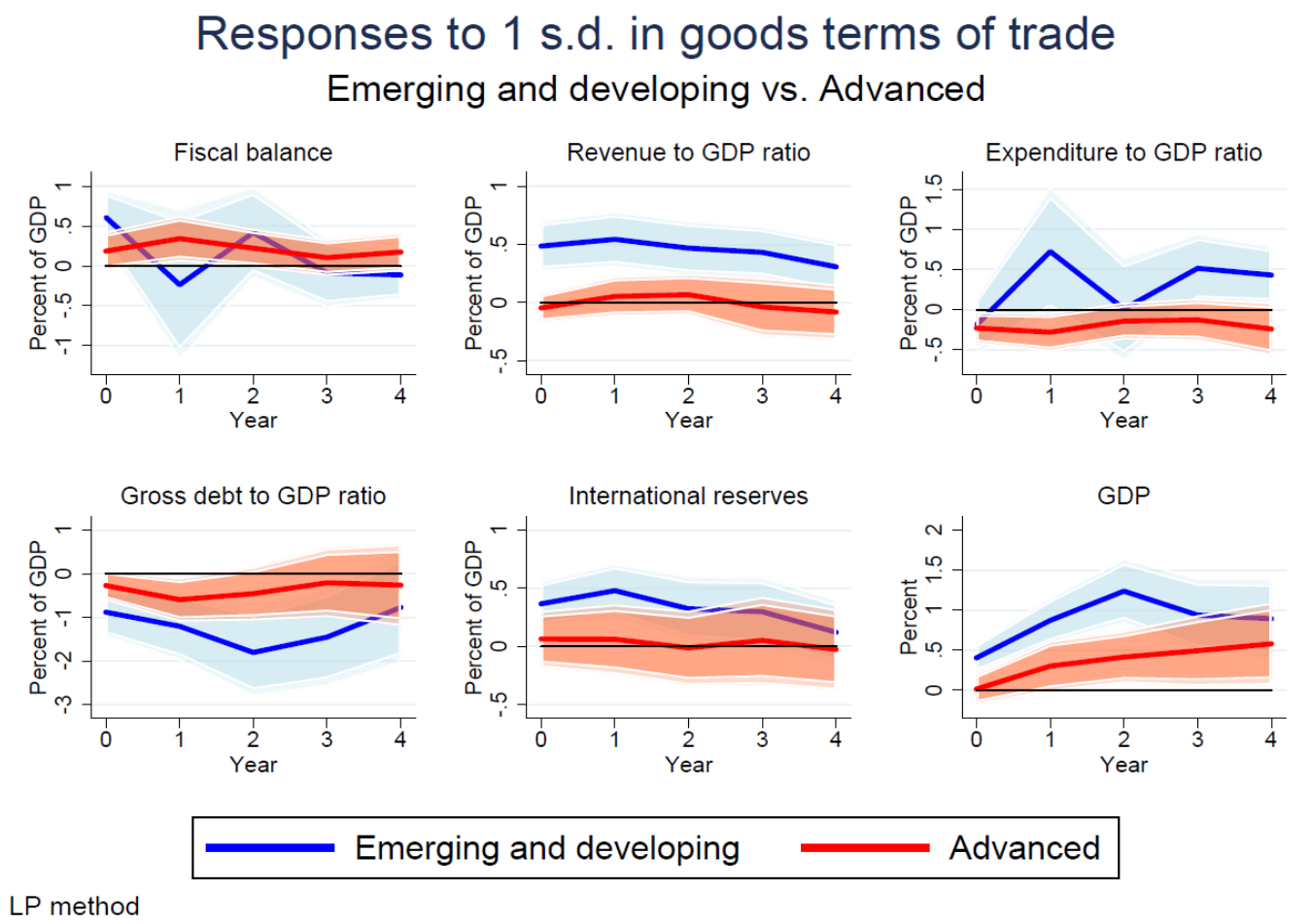

As a substantial part of trade shock form many countries (particularly EMDC) is related to commodity prices, it is interesting to zoom in on the effect of commodity prices and differentiate the shock into the one coming the trade-weighted price of exports versus that of imports, and, for each case to operate further subgroup analysis: between commodity exporters versus non-exporters for the shock to the price of exports; and between advanced versus emerging importers (defined as non-exporters of commodities) for the shock to the price of imports. Hence four cases will be considered. Since commodity prices move in cycle, and countries can be both exporters and importers of commodities, we control for the price of commodity imports when estimating the impact of export prices, and vice versa.

The effect of commodity price of exports is mainly felt by commodity exporters (as a positive wealth and income shock), in terms of higher revenue to GDP and higher GDP itself, lower expenditure ratios, and substantially improved fiscal balance and lower debt to GDP ratios. The effect is instead very small for non-exporters. For commodity exporting countries, the initial impact of a one standard deviation increase in exported commodity prices (where the weights on each commodity price index are given by shares of exports ${ }^{10}$ ) is around $1-1 \frac{1}{2}$ percentage points of GDP on the fiscal balance, resulting roughly equally from the increase in revenue to GDP ratio and the reduction in the expenditure to GDP ratio (affected by the increase in GDP). The effect on the fiscal balance declines somewhat overtime, halving over the horizon, mainly as the revenue effect dissipates. The negative effect on the debt ratio is also strong and persistent. These results are consistent with the expectation that commodity exporters are more likely to witness direct government involvement in commodity exporting activities. As expected, reserves increase in commodity exporters.

\footnotetext{
${ }^{10}$ See Gruss (2014) for the details about the construction of price indices.
} 


\section{Responses to 1 s.d. increase in comm. export prices \\ Commodity exporters vs. Non-exporters}
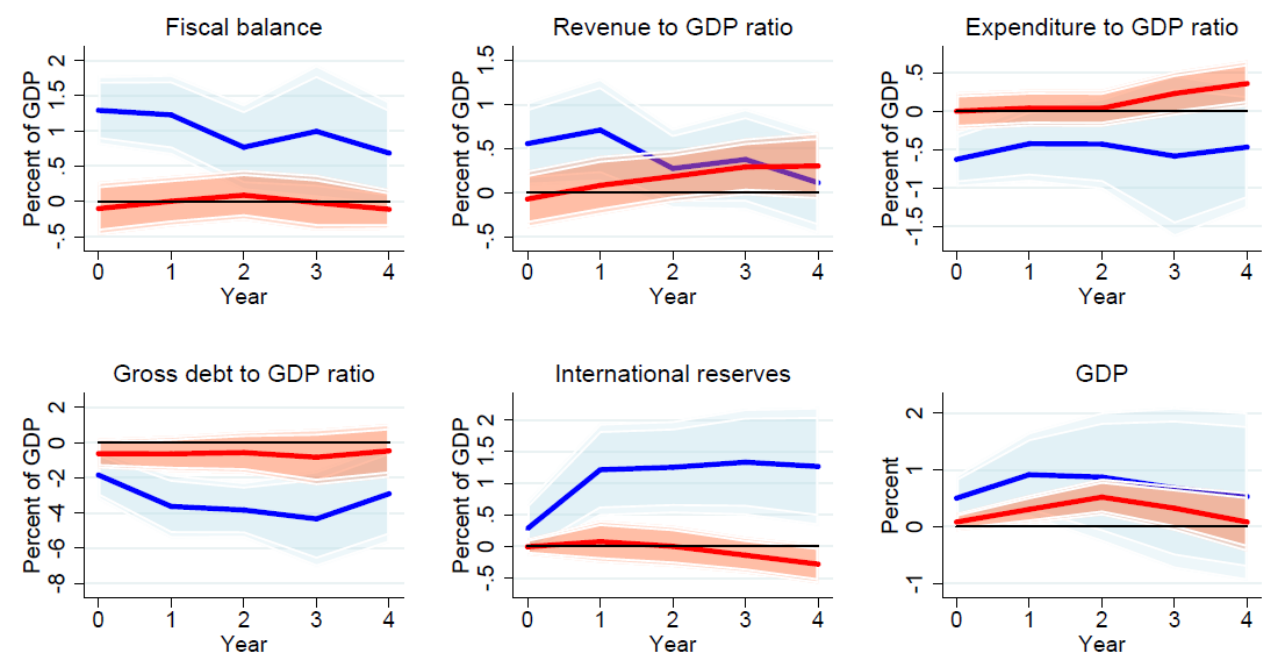

LP method

Commodity exporters

Non-exporters

Imported commodity prices tend to have a similar negative effect on the fiscal balance of advanced or emerging importers (for about $1 / 2$ a percentage point at the peak), but in the former group the effect is mainly via higher expenditure ratios while in the second group it is mainly via lower revenue ratios. The advanced importers tend also to suffer from a stronger decline in GDP which swells the debt ratios, while emerging importers experience declining debt ratios, probably due to reliance on asset sales (for example from a sovereign wealth fund). Reserves decrease in emerging importers. 
Responses to 1 s.d. increase in comm. import prices Emerging importers vs. Advanced importers
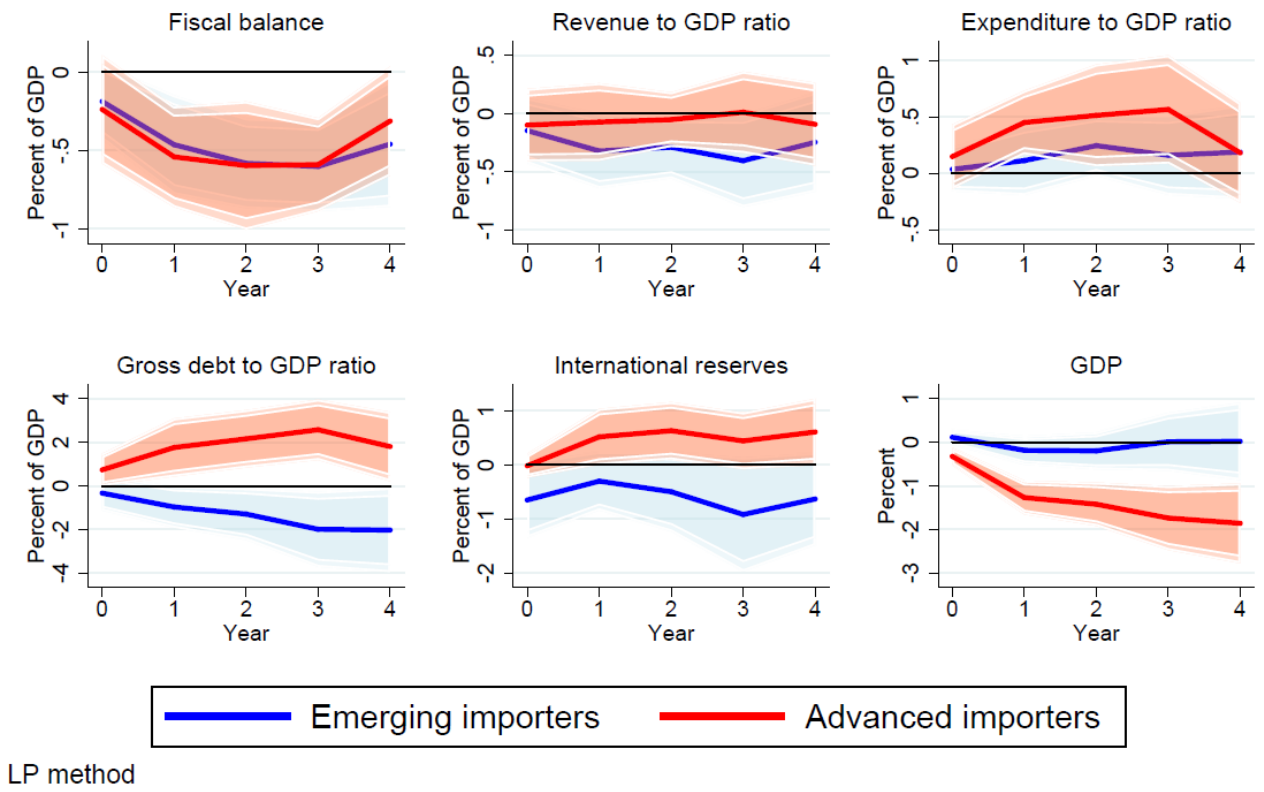

We also explore the effect of commodity shocks via a shock to the oil trade balance. Given the large degree of rigidity in the very short-term in oil imports and exports, one may interpret these computations in the short run as reflecting the fiscal impact of a positive (for exporters) or negative (for importers) oil price shock. The fiscal balance improves in both types of countries, but the effect is somewhat stronger in EMDC, reflecting a more positive effect on revenues, while the increase in GDP induces the usual decline in expenditure ratios. Reserves tend to increase, more persistently in EMDC. 
Responses to 1 p.p. increase in oil trade balance Emerging and developing vs. Advanced
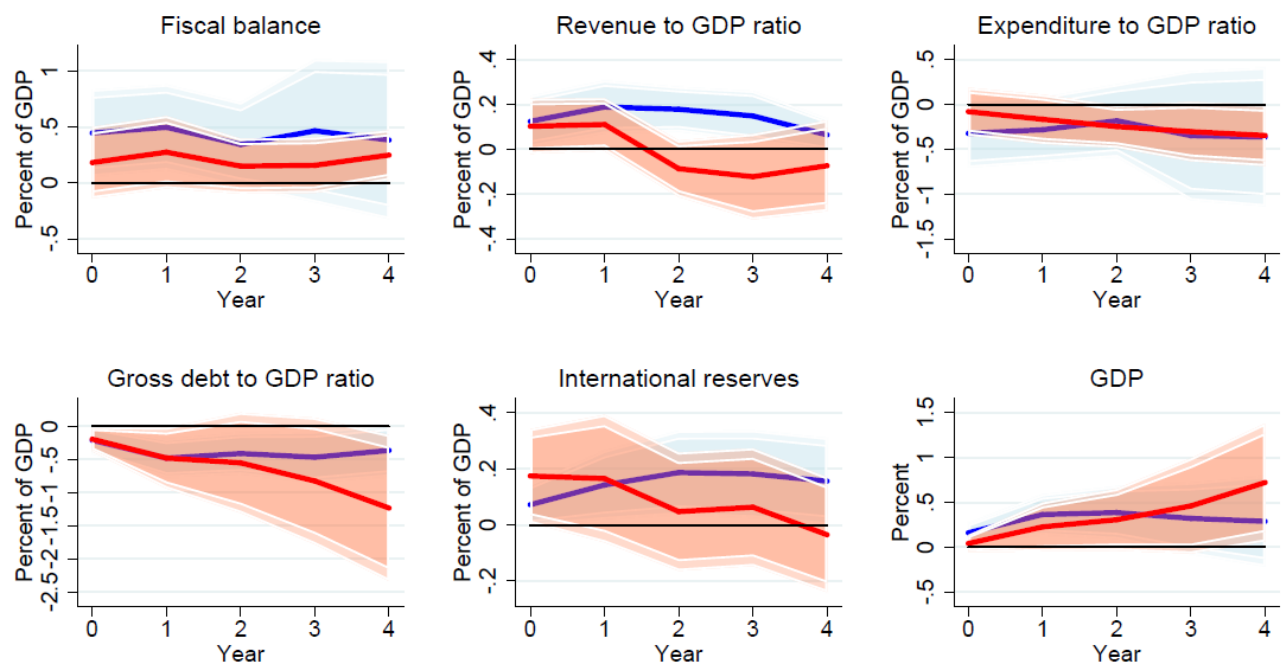

Emerging and developing

\section{Advanced}

LP method

\section{The effect of global risk appetite}

We compute the effect of the VIX (normalized by demeaning it and dividing by its standard deviation), controlling for world inflation, as well as lags of the dependent and explanatory variables.

\section{Responses to 1 s.d. increase in VIX Emerging and developing vs. Advanced}
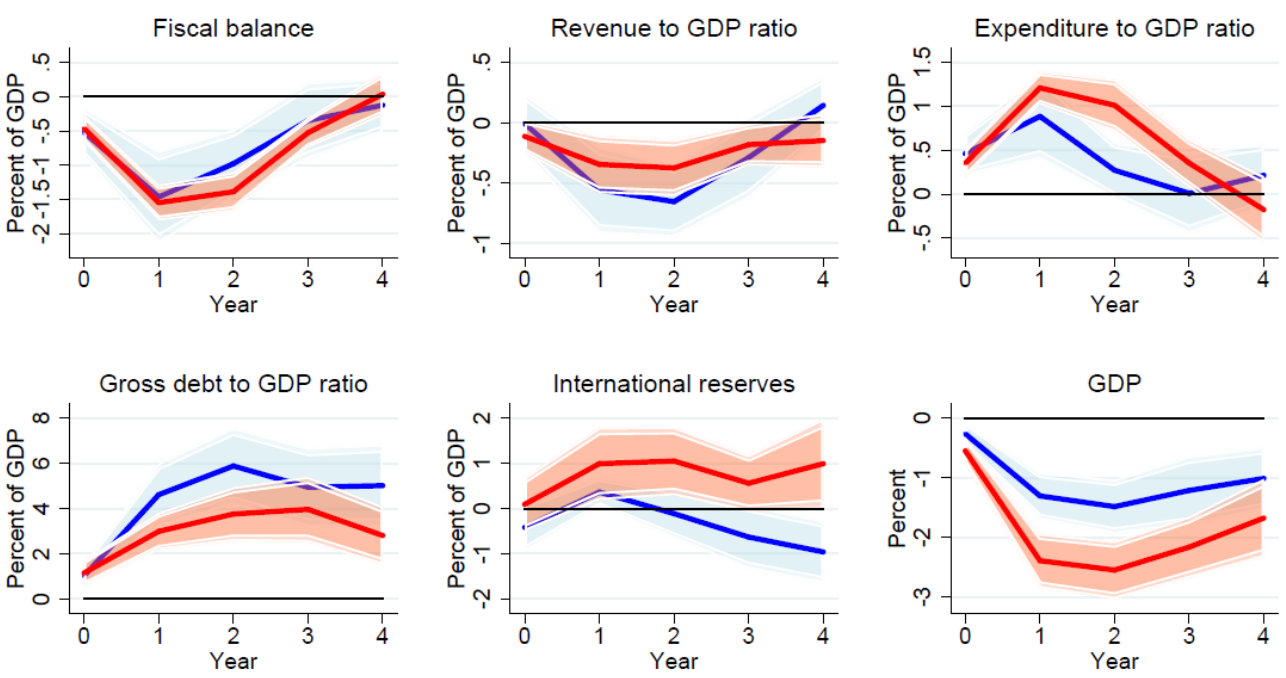

Emerging and developing

Advanced

LP method 
The effect on the fiscal balance is negative and large for all countries: a one standard deviation increase in the VIX worsens the fiscal balance by about 0.5 percent of GDP on impact, and the effect grows after one year to around 1.5 percentage point of GDP, and then fades away only after 4 years The effect occurs both through lower revenue and higher expenditure ratios, and the effect on the expenditure ratio is stronger in advanced economies mainly reflecting the larger GDP drop (denominator effect). After two years, the gross debt to GDP ratio raises by four percentage points of GDP in $\mathrm{AE}$ and six percentage points in EMDC, in part due to the visible exchange rate depreciations in EMDC (unlike in AE), which plays a role as a shock absorber but at the same time generates a negative balance sheet effect. Reserves tend to decline in EMDC and increase in $\mathrm{AE}$, consistent with the story that capital flows to safer countries after a risk aversion shock.

When separating the effect of VIX for external creditors and debtors, we see that the effect of an increase in the VIX on public debt accumulation is both more pronounced and more persistent among external debtors than external creditors, and so is the drop in GDP, partly because debtors face a stronger nominal exchange rate depreciation.
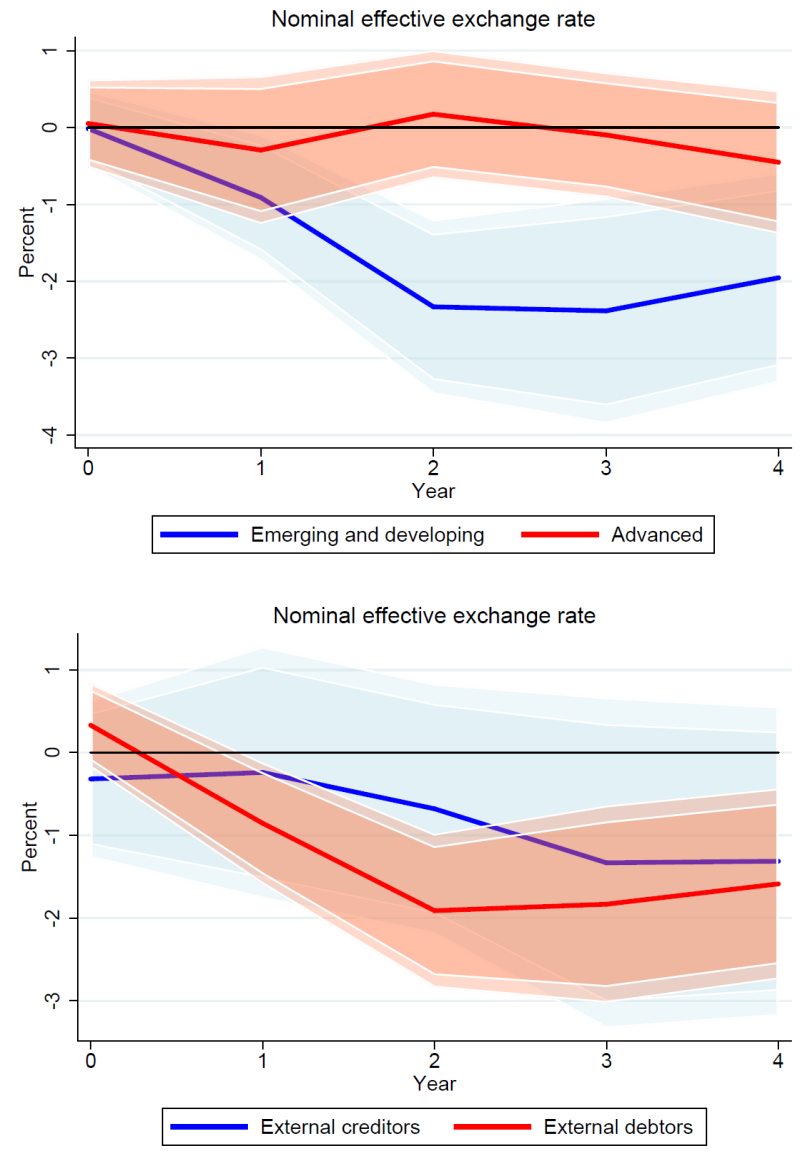
Responses to 1 s.d. increase in VIX

External creditors vs. External debtors
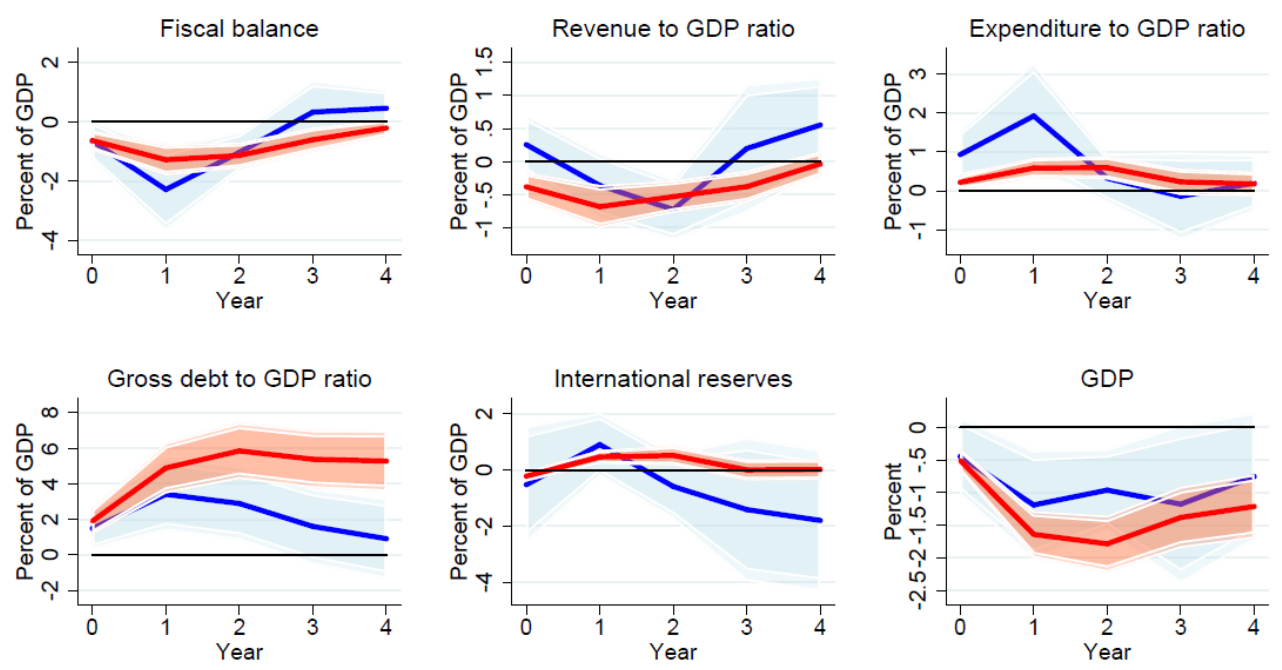

External creditors

External debtors

LP method

US interest rates provide an additional proxy for global financing conditions, but they may also constitute a leading indicator of the global cycle (see e.g. Ang et al. 2006). Indeed, following a rise of one point in US long-term bond yields (controlling for Fed fund rates which proxy for short-term interest rates in the US, and contemporaneous but not future GDP), we observe an increase in GDP in advanced economies (and a smaller one in EMDC), and a progressive improvement in the fiscal balance ratio to GDP in both advanced and emerging economies (by about 1 percentage point after 2 years), suggesting the latter group tends to have stronger fiscal elasticities to GDP. Despite the improvement in the fiscal balance, gross debt in EMDC tends to rise, likely reflecting the burden from higher interest rates. 


\section{Responses to 1 p.p. US10-yr yield}

Emerging and developing vs. Advanced
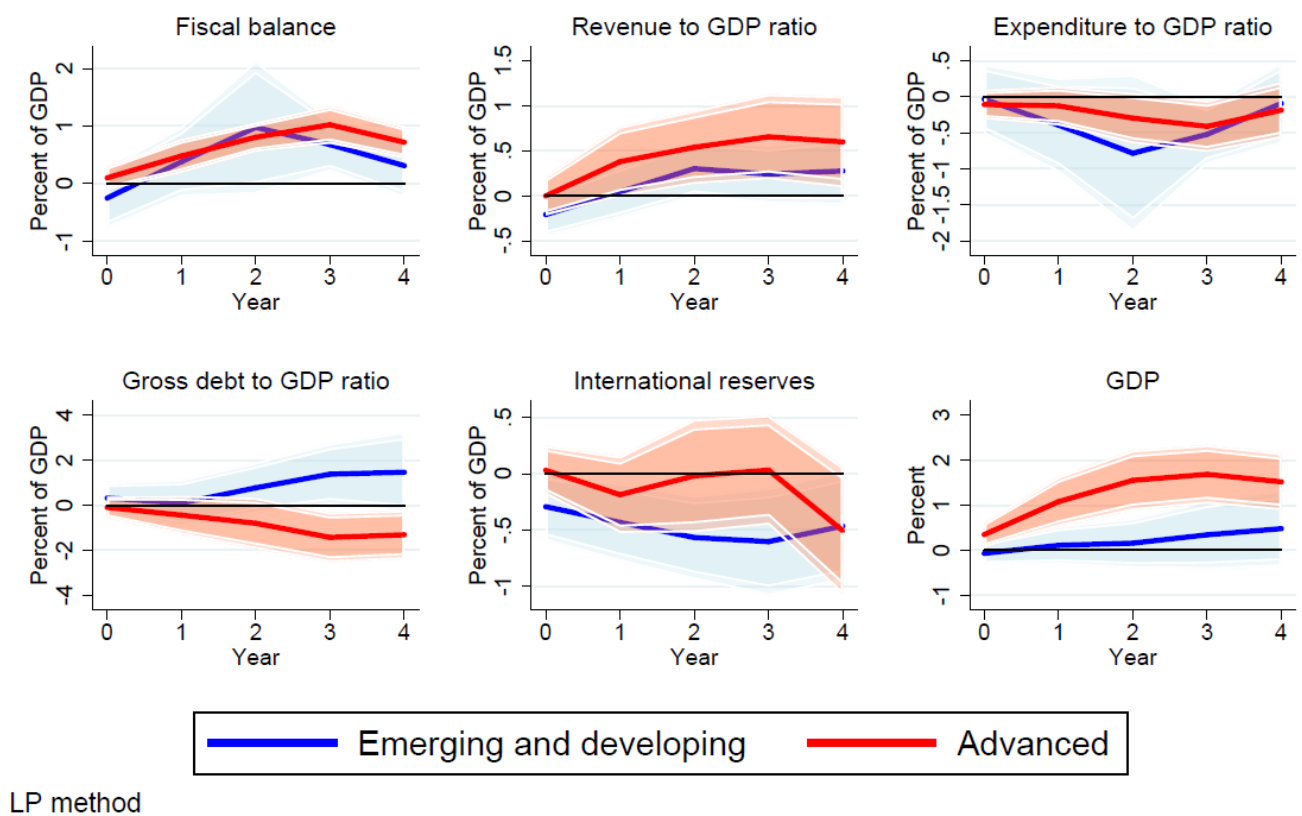

\section{The effect of political shocks and conflicts}

A significant literature on political economy has suggested that election years increase expenditure. On the basis of a dummy for the categorization of a year as an election year, we find that elections are associated with higher spending, worse fiscal balance, and rising debt, in EMDC - although the effect is mainly significant in the medium term - but not in AE. These results are consistent with findings of the existence of a stronger "political fiscal cycle" (Brender and Drazen, 2005) in countries with weaker institutional checks and balances on the power of the executive. 
Responses to election year

Emerging and developing vs. Advanced
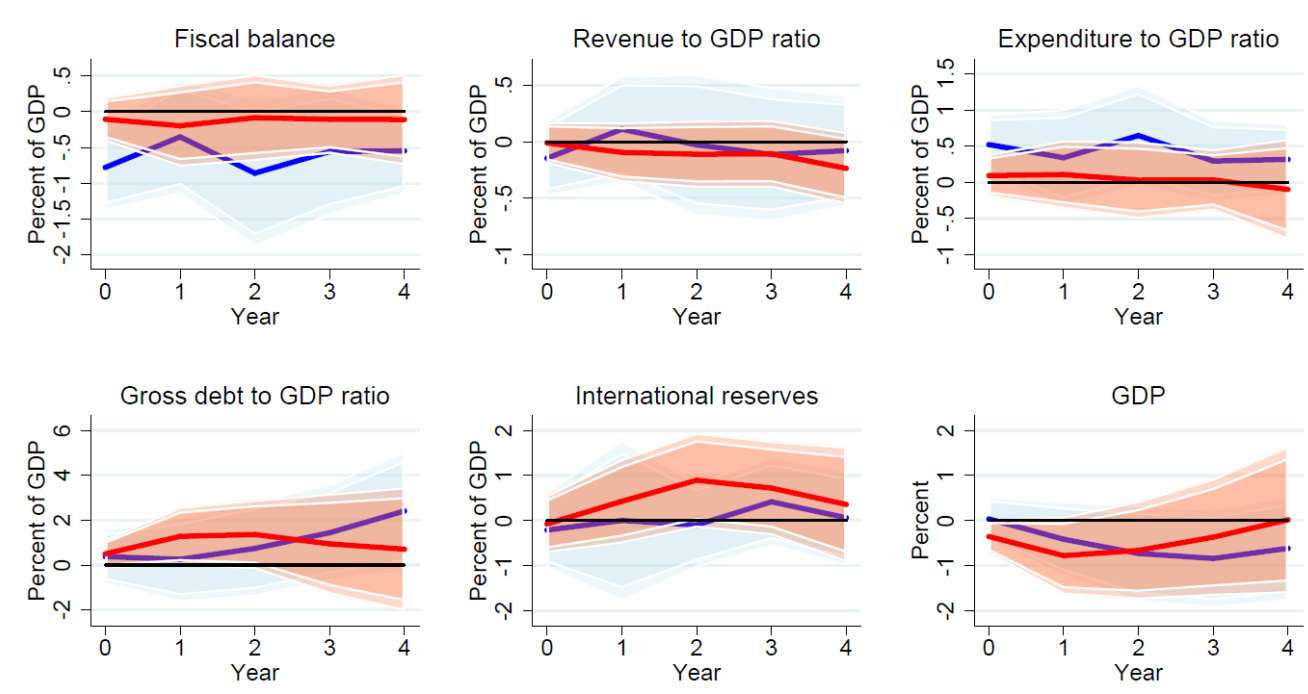

Emerging and developing

Advanced

LP method

In EMDC, political transition years (or "regime changes", as defined by their coding in the Polity IV database) are associated with a large decline in GDP, and a likely destabilization of the fiscal framework, visible in lower revenue, higher expenditure, and a lower overall fiscal balance, as well as increased debt to GDP ratio. The results, however, are imprecisely estimated, due to the relatively low number of political regime change events in our sample.

\section{Responses to first year of regime change in EMDC Emerging}
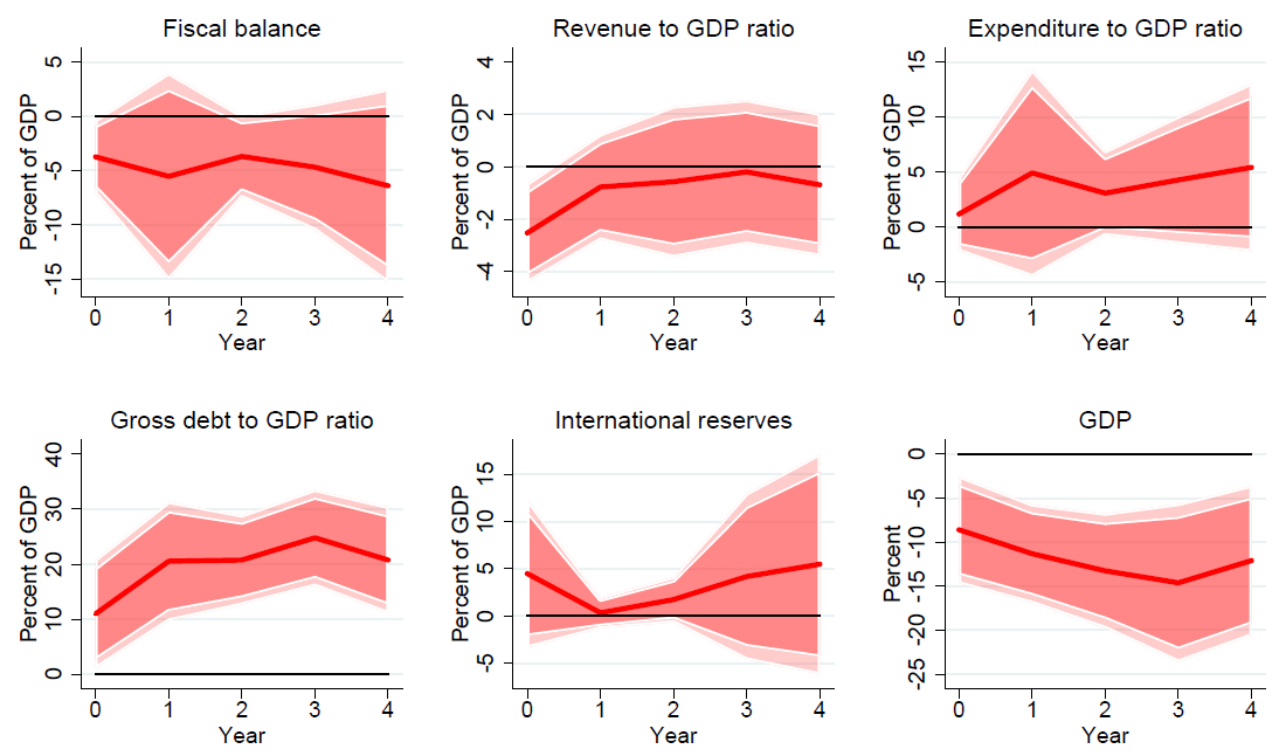

LP method 
We study the differential effects of the last year of political transitions (a "transition" shock) in EMDC, depending on whether such transitions are followed by more or less democratic regimes. A political transition out of democracy for EMDC (as defined in the polity IV database which is observed only in emerging and developing economies in our sample) has a very large and persistent negative impact on fiscal balance, mainly through substantially higher spending ratios and lower GDP, despite a relatively small improvement in revenue ratios. ${ }^{11}$ This leads to persistently higher public debt ratios (with magnitudes rising around 20 percentage points of GDP increases after two years). Transitions into democracy for EMDC are instead met with an improvement of the fiscal position, but of a much smaller magnitude, associated with an increase in GDP and revenue ratios; the ensuing decline in debt is substantial, possibly reflecting debt restructuring/relief following the political transition.

\section{Responses to transition shock}
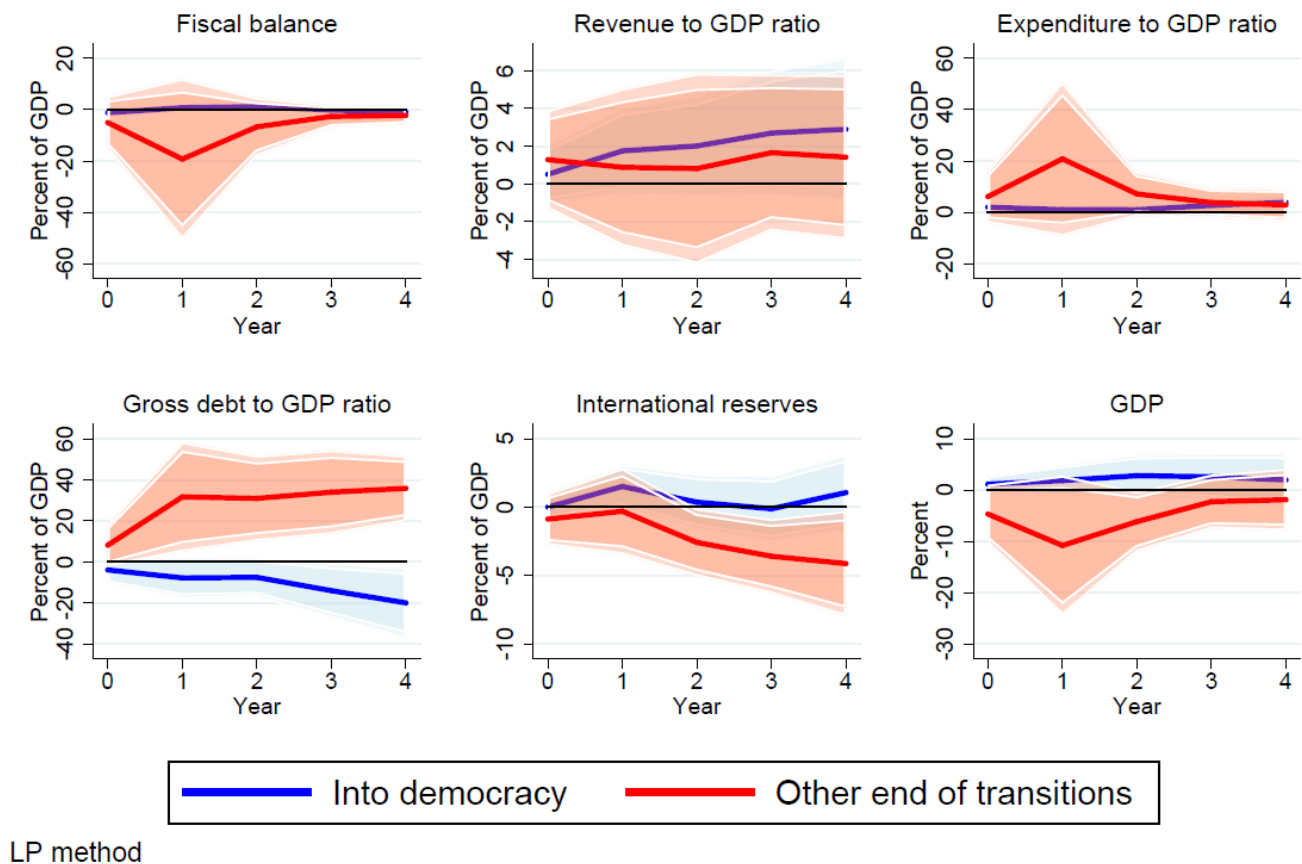

The effect of an increase in military spending in EMDC (taken from the SIPRI military expenditure database, with a somewhat smaller coverage) gives rise to an effect qualitatively similar to the transition out of democracy, with rising expenditure ratios, worsening revenue and fiscal balance ratios, declining GDP, and rising public debt ratios. Part of the response obviously corresponds to the mechanical accounting result from higher military expenditures to GDP; but part is associated with the

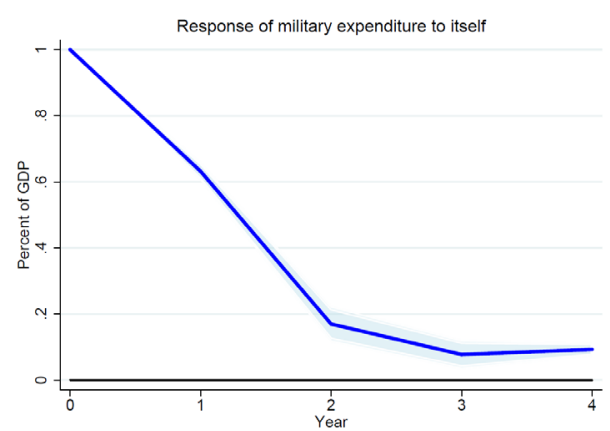

${ }^{11} \mathrm{We}$ focus on the last year of a transition, to avoid spurious results caused by the persistence of transitions for several years in the sample. 
persistence of the fiscal impact (relative to the persistence of the military expenditure shock itself, shown here), as well as the absence of offset through higher revenue or lower expenditure in other categories. While military spending is positively associated with an increase in growth in AE over time (as in the standard literature), the same does not happen in EMDC, maybe reflecting the possibility that in EMDC such military spending increases at time of economic distress. At the same time, an increase in military spending is associated with a stronger decline in expenditure ratios in $\mathrm{AE}$, which would in part reflect the better growth outcome in $\mathrm{AE}$, but may also result from stronger fiscal discipline and crowding out discretionary policies to maintain fiscal targets in these countries.

\section{Responses to 1 p.p. increase in military exp./GDP Emerging and developing vs. Advanced}
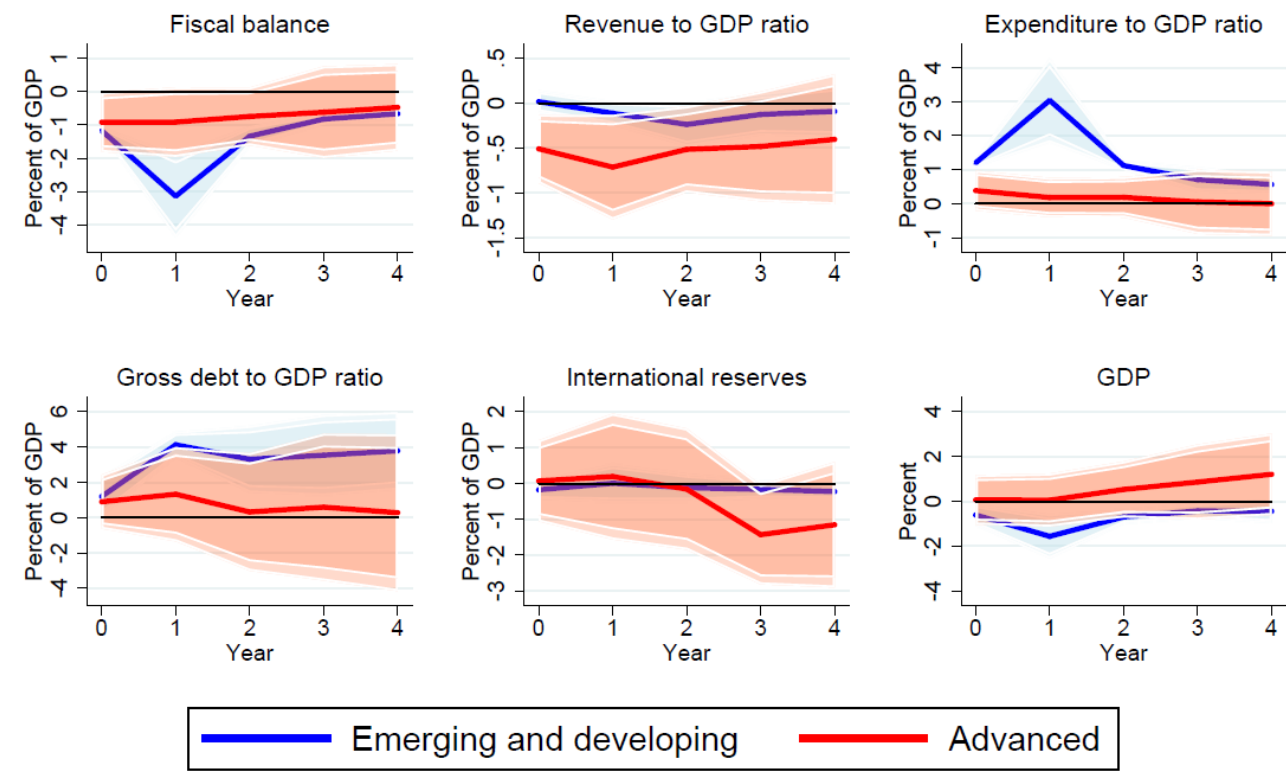

LP method

\section{The effect of domestic financial variables}

We study the dynamic fiscal response to some of our domestic financial variables, although it should be noted that data coverage is more limited than for other shocks.

A banking crisis is one of the few shocks that has a much larger impact on fiscal variables in $\mathrm{AE}$ than in EMDC. In the former set of countries, a banking crisis heavily worsens expenditure, revenues, fiscal balance and debt ratios, while significantly affecting real GDP. In the latter group of countries, the effects are more muted for most fiscal ratios and GDP outcomes, although the effect on revenues is quite similar to the one in AE. Part of the increase in public debt to GDP ratios in advanced economies is the result of the occurrence of bank recapitalizations (see e.g. Laeven, Valencia, 2008), while the effect on public debt is less visible in emerging economies (possibly because banking crises are often followed by sovereign debt restructurings, which can decrease debt ratios), and the effect on fiscal balances is much less persistent (one hypothesis being the occurrence of external bailouts for these countries, unlike in advanced economies). 


\section{Responses to banking crisis}

\section{Emerging and developing vs. Advanced}
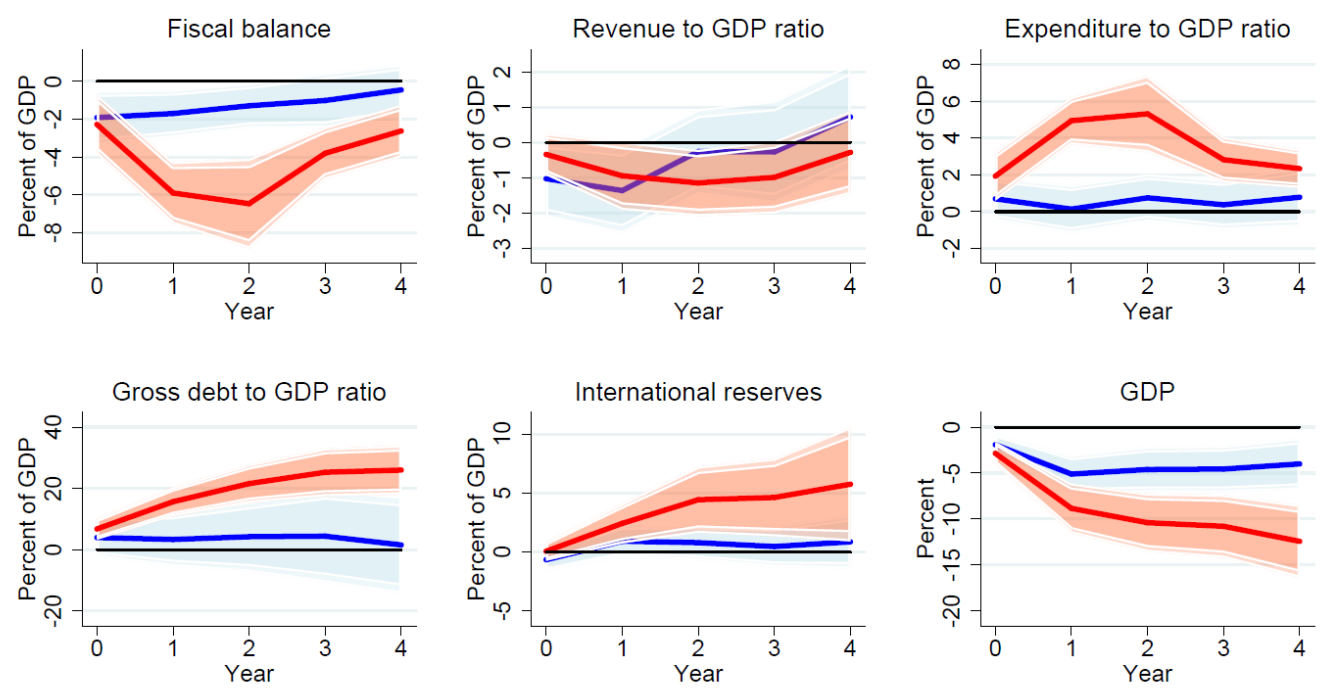

Emerging and developing

\section{Advanced}

LP method

The effect of demographic shocks variables

Responses to 1 p.p. increase in detrended population

Emerging and developing vs. Advanced
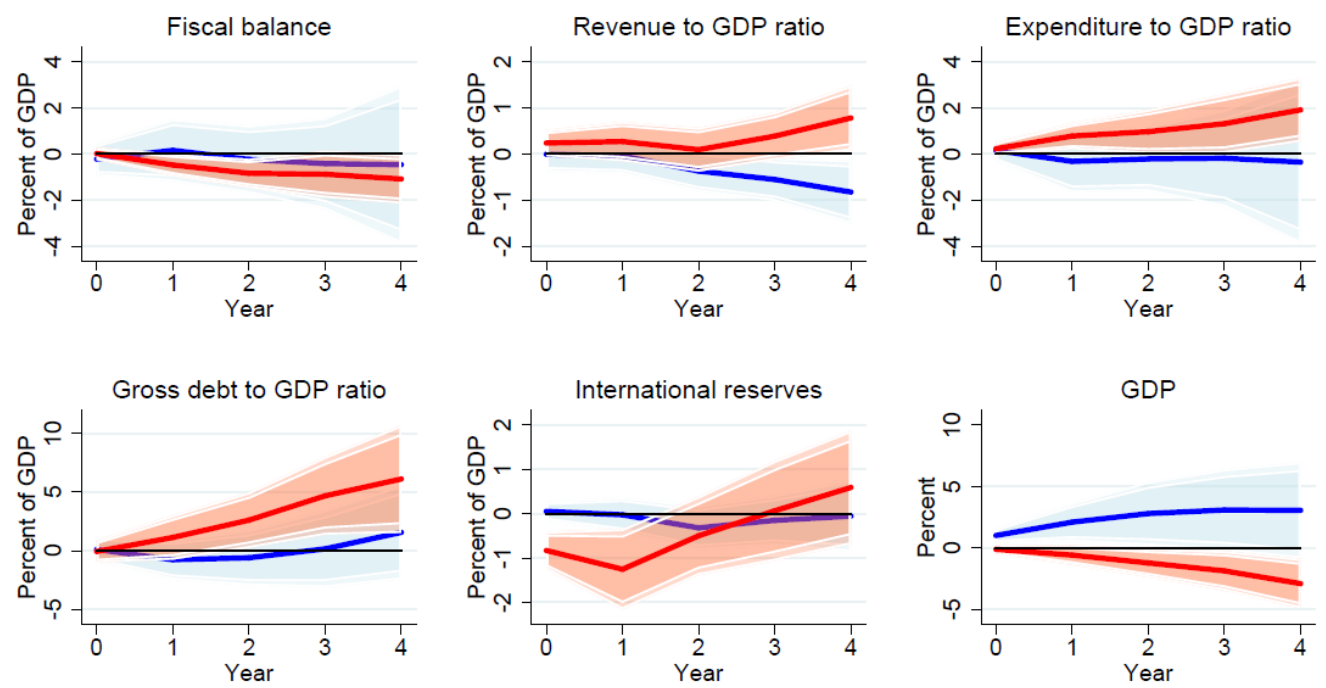

Emerging and developing

Advanced

LP method 
Population increases (measured as the percentage deviation from the countryspecific quadratic trend) are associated in advanced economies with persistent and significant deteriorations of the fiscal balance and debt to GDP ratios, mostly through higher expenditure ratios (and despite higher revenue ratios) and lower GDP (maybe as in $\mathrm{AE}$ an increase in population mainly occurs via aging), suggesting that the provision of safety nets plays a key role. Reserves decline in $\mathrm{AE}$, suggesting a worsening of the external

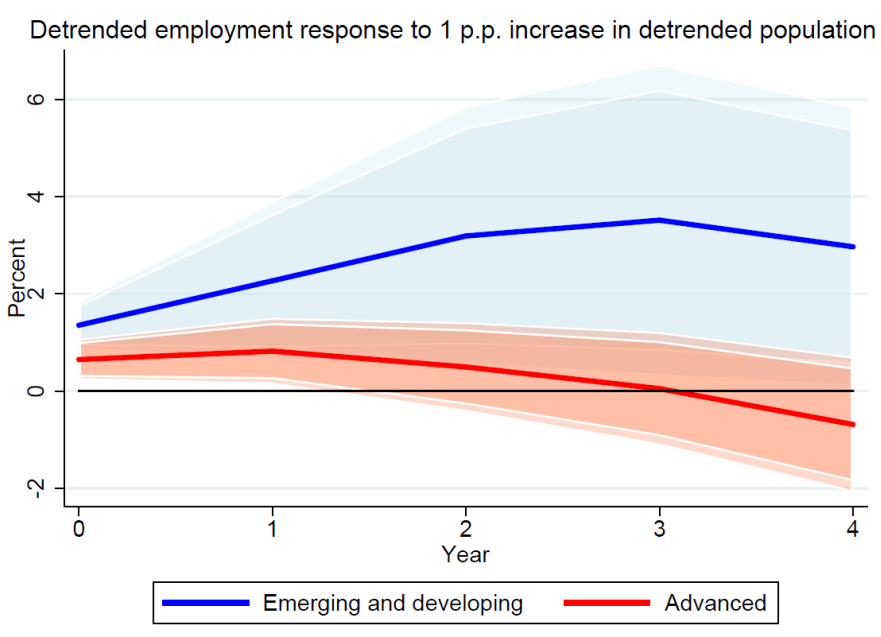
position. In EMDC, the effect on GDP is positive, but both revenue and expenditure ratios decline, leaving the fiscal balance roughly unchanged. This seems consistent with the idea that an increased population is associated with larger employment response in emerging economies than in advanced economies (see chart) where old age dependency ratios increase.

\section{i. Dynamic Panel Methods}

To confirm the robustness of our dynamic local projection estimators, the next step in our estimation strategy relies on running fixed-effects panel regressions of fiscal outcomes on the exogenous shocks. The specification includes one lag of the dependent variable, and several "blocks" of independent variables, along the following specification:

$$
\begin{aligned}
y_{i t}=\alpha_{i}+\rho y_{i, t-1} & \\
& +\left[\beta_{[\text {trade }]} X_{[\text {trade }] i t}+\beta_{[\text {world }]} X_{[\text {world }] \text { it }}+\beta_{[\text {finance }]} X_{[\text {finance }] \text { it }}\right. \\
& \left.+\beta_{[\text {domestic }]} X_{[\text {domestic }] i t}\right]+\varepsilon_{i t}
\end{aligned}
$$

The parameter of interest are the within-country responses $\beta_{[b l o c k]}$ to various blocks of explanatory variables $X_{[\text {block }] i t}$. Heterogeneous effects of some exogenous shocks across countries are estimated by interacting key variables with specific dummies reflecting a commodity-exporter status (as defined in the IMF database), or the level of development status (advanced versus others). The regressions control for the level of development (proxied by real GDP per capita in PPP terms), as this may have an impact on the fiscal outcomes. We use robust standard errors allowing for heteroskedasticity at the country cluster level, with the degrees of freedom adjusted by the number of country clusters.

The main baseline results are reported in the text for the whole sample, while Annex IV shows the results for various country subgroups (including advanced economies, emerging and developing economies, and Latin America and Caribbean countries).

\section{Main results}

Overall the regression table below shows similar results with respect the impact estimated in the LP method. Standard panel regressions results are very consistent with the local projections 
results for some of the key shocks, notably world growth, VIX, U.S. 10-year rate, political transitions, banking crises, and population increase. With respect to trade shock, due to obvious collinearity of the various measures, the most relevant in this context turned out to be commodity prices, divided into import and export prices, and interacted with exporter or importer dummy respectively: the fiscal effects are similar to the LP effects for emerging exporters and importers (note that the effect of commodity export prices for commodity exporters would be given by the sum of the two coefficients of "commodity export price change" and "commodity export price change x exporter"; similarly for the effect of import prices for importers), and the GDP effect are similar for AE. In the standard panel regressions results we also include the natural disasters, which worsen the fiscal balance, debt ratios, and GDP, but mainly for small countries (due to the effect being limited to a small group of countries, such a shock was not attempted in the local projection method). The regressions do not include military spending and oil trade balance, while elections are tested separately below given the more limited subsample due to reduced data coverage.

\section{Other robustness checks}

We implement robustness checks on our initial estimates, either by entering additional explanatory variables such as election, or via alternative estimating strategies that address remedying potential biases due to the nature of our dynamic panel data (Arellano-Bond). ${ }^{12}$

\section{Shorter dataset with domestic election years}

When including election years (available only since 1995), we lose a large number of early observations. Nonetheless, results are in line with the local projection method and the standard panel regressions: At the same time, the sign and magnitude of most other estimates remains unchanged, although significance is occasionally weaker. Domestic election years tend to raise expenditures, with the effect more visible in emerging economies, and thus lead to a short-term deterioration in the fiscal balances; the effect is not observed in advanced economies.

\footnotetext{
${ }^{12}$ We also perform additional robustness by including domestic financial conditions available for a subsample of countries: long-term domestic rates, stock market volatility, and private credit growth (results available upon request).
} 


\begin{tabular}{|c|c|c|c|c|c|c|c|c|}
\hline All countries, main specification & Fiscal balance & Revenue & Expenditure & Gross debt & Net debt & $\begin{array}{l}\text { Reserves to } \\
\text { GDP }\end{array}$ & GDP growth & NEER change \\
\hline L. Overall fiscal balance, $\%$ of GDP & $\begin{array}{l}0.640^{* * * *} \\
{[0.0828]}\end{array}$ & & & & & & & \\
\hline Annual world real GDP growth, percent & $\begin{array}{l}0.396^{* * * *} \\
{[0.0966]}\end{array}$ & $\begin{array}{c}0.186^{*} \\
{[0.100]}\end{array}$ & $\begin{array}{c}-0.253^{* * * *} \\
{[0.0587]}\end{array}$ & $\begin{array}{c}-0.744^{* * *} \\
{[0.256]}\end{array}$ & $\begin{array}{l}-0.831^{* *} \\
{[0.339]}\end{array}$ & $\begin{array}{c}-0.297^{* * *} \\
{[0.107]}\end{array}$ & $\begin{array}{l}0.654^{* * * *} \\
{[0.0799]}\end{array}$ & $\begin{array}{l}-0.367^{* *} \\
{[0.164]}\end{array}$ \\
\hline Standardized VIX & $\begin{array}{l}-0.244^{* * * *} \\
{[0.0607]}\end{array}$ & $\begin{array}{c}-0.177^{* * * *} \\
{[0.0504]}\end{array}$ & $\begin{array}{c}0.0831 \\
{[0.0551]}\end{array}$ & $\begin{array}{l}0.692^{* * *} \\
{[0.221]}\end{array}$ & $\begin{array}{l}0.0116 \\
{[0.287]}\end{array}$ & $\begin{array}{c}-0.128 \\
{[0.0886]}\end{array}$ & $\begin{array}{l}-0.155^{* *} \\
{[0.0698]}\end{array}$ & $\begin{array}{c}-0.410^{* * * *} \\
{[0.151]}\end{array}$ \\
\hline Commodity export price change, normalized & $\begin{array}{l}-0.0257 \\
{[0.130]}\end{array}$ & $\begin{array}{l}-0.142 \\
{[0.105]}\end{array}$ & $\begin{array}{l}-0.136 \\
{[0.117]}\end{array}$ & $\begin{array}{l}-0.709^{*} \\
{[0.410]}\end{array}$ & {$[0.410$} & $\begin{array}{l}-0.0857 \\
{[0.107]}\end{array}$ & $\begin{array}{c}0.0994 \\
{[0.0871]}\end{array}$ & $\begin{array}{l}0.404^{*} \\
{[0.213]}\end{array}$ \\
\hline $\begin{array}{l}\text { Commodity export price change, normalized } \mathrm{x} \\
\text { exporter }\end{array}$ & $\begin{array}{l}1.390^{* * * *} \\
{[0.314]}\end{array}$ & $\begin{array}{c}0.866^{* * * *} \\
{[0.221]}\end{array}$ & $\begin{array}{l}-0.564^{* *} \\
{[0.236]}\end{array}$ & $\begin{array}{l}-1.565 \\
{[0.980]}\end{array}$ & $\begin{array}{l}-2.814^{*} \\
{[1.549]}\end{array}$ & $\begin{array}{c}0.211 \\
{[0.173]}\end{array}$ & $\begin{array}{c}0.176 \\
{[0.187]}\end{array}$ & $\begin{array}{c}0.229 \\
{[0.526]}\end{array}$ \\
\hline Commodity import price change, normalized & $\begin{array}{l}0.627^{* * *} \\
{[0.215]}\end{array}$ & $\begin{array}{c}0.247 \\
{[0.213]}\end{array}$ & $\begin{array}{l}{[0.178} \\
-0.178 \\
{[0.168]}\end{array}$ & $\begin{array}{l}-1.300^{*} \\
{[0.694]}\end{array}$ & $\begin{array}{l}-0.181 \\
{[0.777]}\end{array}$ & $\begin{array}{l}0.175] \\
-0.105 \\
{[0.172]}\end{array}$ & {$[0.166$} & $\begin{array}{l}{[0.020]} \\
-0.0145 \\
{[0.351]}\end{array}$ \\
\hline $\begin{array}{l}\text { Commodity import price change, normalized } \mathrm{x} \\
\text { importer }\end{array}$ & $\begin{array}{l}-0.602^{* *} \\
{[0.242]}\end{array}$ & $\begin{array}{l}-0.287 \\
{[0.226]}\end{array}$ & $\begin{array}{c}0.181 \\
{[0.207]}\end{array}$ & $\begin{array}{l}1.160 \\
{[0.814]}\end{array}$ & -0.0619 & $\begin{array}{l}-0.350 \\
{[0.246]}\end{array}$ & $\begin{array}{l}-0.0820 \\
{[0.219]}\end{array}$ & $\begin{array}{l}0.525 \\
{[0.398]}\end{array}$ \\
\hline $\begin{array}{l}\text { US government } 10 \text {-year constant maturity bond yield, } \\
\text { percent }\end{array}$ & $\begin{array}{c}0.0231 \\
{[0.0572]}\end{array}$ & $\begin{array}{l}-0.133^{* * *} \\
{[0.0461]}\end{array}$ & $\begin{array}{l}-0.146^{* * *} \\
{[0.0468]}\end{array}$ & $\begin{array}{c}0.159 \\
{[0.131]}\end{array}$ & $\begin{array}{l}-0.408^{* *} \\
{[0.192]}\end{array}$ & $\begin{array}{l}-0.126 \\
{[0.117]}\end{array}$ & $\begin{array}{c}0.0781 \\
{[0.0485]}\end{array}$ & $\begin{array}{c}-0.349^{* * *} \\
{[0.126]}\end{array}$ \\
\hline Transition year dummy, from PolityIV & $\begin{array}{l}-3.759^{*} \\
{[1.956]}\end{array}$ & $\begin{array}{c}-1.462^{* * *} \\
{[0.463]}\end{array}$ & $\begin{array}{l}2.165 \\
{[1.682]}\end{array}$ & $\begin{array}{l}8.755^{* * *} \\
{[3.321]}\end{array}$ & $18.86^{* *}$ & $\begin{array}{l}4.724 \\
{[4.362]}\end{array}$ & $\begin{array}{l}-3.667^{*} \\
{[2.070]}\end{array}$ & $\begin{array}{l}-1.244 \\
{[1.158]}\end{array}$ \\
\hline Systemic banking crisis from Laeven-Valencia & $\begin{array}{l}-0.628 \\
{[0.396]}\end{array}$ & $\begin{array}{l}-0.0185 \\
{[0.434]}\end{array}$ & $\begin{array}{c}0.704 \\
{[0.478]}\end{array}$ & $\begin{array}{l}5.839^{* *} \\
{[2.278]}\end{array}$ & $\begin{array}{l}4.001 \\
{[2.625]}\end{array}$ & $\begin{array}{l}-0.838^{*} \\
{[0.441]}\end{array}$ & $\begin{array}{l}-2.135^{* * * *} \\
{[0.471]}\end{array}$ & $\begin{array}{l}-1.338 \\
{[1.351]}\end{array}$ \\
\hline Log population, deviation from quadratic trend & $\begin{array}{l}-0.140^{* *} \\
{[0.0546]}\end{array}$ & $\begin{array}{l}-0.00821 \\
{[0.0182]}\end{array}$ & $\begin{array}{c}0.107^{*} \\
{[0.0555]}\end{array}$ & $\begin{array}{l}0.0233 \\
{[0.0810]}\end{array}$ & $\begin{array}{l}-0.0920 \\
{[0.136]}\end{array}$ & -0.00286 & $\begin{array}{l}-0.0791^{* * *} \\
{[0.0252]}\end{array}$ & $\begin{array}{l}-0.00114 \\
{[0.0427]}\end{array}$ \\
\hline $\begin{array}{l}\text { Log population, deviation, interacted with advanced } \\
\text { dummy }\end{array}$ & $\begin{array}{l}-0.0993 \\
{[0.129]}\end{array}$ & $\begin{array}{c}0.0507 \\
{[0.0529]}\end{array}$ & {$[0.127$} & $\begin{array}{l}0.949^{* * *} \\
{[0.351]}\end{array}$ & $0.946^{* *}$ & $\begin{array}{l}0.132 \\
{[0.102]}\end{array}$ & $\begin{array}{l}-0.280^{* *} \\
{[0.111]}\end{array}$ & $\begin{array}{l}-0.157 \\
{[0.134]}\end{array}$ \\
\hline Damages from natural disasters, USD bn & $\begin{array}{l}-0.226^{* *} \\
{[0.0949]}\end{array}$ & $\begin{array}{l}-0.217 \\
{[0.151]}\end{array}$ & $\begin{array}{l}0.00483 \\
{[0.169]}\end{array}$ & $\begin{array}{l}1.023^{* * * *} \\
{[0.275]}\end{array}$ & $\begin{array}{l}1.490^{* * *} \\
{[0.476]}\end{array}$ & $\begin{array}{l}0.195 \\
{[0.170]}\end{array}$ & $\begin{array}{l}-0.322^{*} \\
{[0.169]}\end{array}$ & $\begin{array}{l}-0.134 \\
{[0.294]}\end{array}$ \\
\hline Damages from natural disasters $\mathrm{x} \log$ population & $\begin{array}{l}0.0115^{* *} \\
{[0.00480]}\end{array}$ & $\begin{array}{c}0.0116 \\
{[0.00805]}\end{array}$ & $\begin{array}{l}0.000212 \\
{[0.00897]}\end{array}$ & $\begin{array}{c}-0.0502^{* * * *} \\
{[0.0141]}\end{array}$ & $\begin{array}{c}-0.0768^{* * *} \\
{[0.0249]}\end{array}$ & $\begin{array}{c}-0.0100 \\
{[0.00899]}\end{array}$ & $\begin{array}{c}0.0162^{*} \\
{[0.00876]}\end{array}$ & $\begin{array}{l}0.00732 \\
{[0.0156]}\end{array}$ \\
\hline L.Overall government revenue, $\%$ of GDP & & $\begin{array}{l}0.699^{* * * *} \\
{[0.0621]}\end{array}$ & & & & & & \\
\hline L.Overall government expenditure, $\%$ of GDP & & & $\begin{array}{l}0.835^{* * * *} \\
{[0.0565]}\end{array}$ & & & & & \\
\hline L.Public debt, $\%$ of GDP, HPDD & & & & $\begin{array}{l}0.912^{* * * *} \\
{[0.0192]}\end{array}$ & & & & \\
\hline L.General govt net debt, $\%$ of GDP & & & & & $\begin{array}{l}0.944^{* * * *} \\
{[0.0100]}\end{array}$ & & & \\
\hline L.International reserves, $\%$ of USD GDP, EWN & & & & & & $\begin{array}{c}0.964^{* * * *} \\
{[0.102]}\end{array}$ & & \\
\hline L.Annual real GDP growth, percent & & & & & & & $\begin{array}{l}0.202^{* * * *} \\
{[0.0519]}\end{array}$ & \\
\hline $\begin{array}{l}\text { L.Change in the nominal effective exchange rate, } \\
\text { percent }\end{array}$ & & & & & & & & $\begin{array}{l}0.345^{* * * *} \\
{[0.0311]}\end{array}$ \\
\hline Constant & $\begin{array}{l}-2.355^{* * * *} \\
{[0.491]}\end{array}$ & $\begin{array}{c}8.651^{* * * *} \\
{[1.617]}\end{array}$ & $\begin{array}{c}6.825^{* * * *} \\
{[1.685]}\end{array}$ & $\begin{array}{c}6.649^{* * * *} \\
{[1.672]}\end{array}$ & $\begin{array}{c}6.018^{* * * *} \\
{[1.642]}\end{array}$ & $\begin{array}{c}2.744 \\
{[2.100]}\end{array}$ & $\begin{array}{c}0.332 \\
{[0.376]}\end{array}$ & $\begin{array}{c}1.687^{*} \\
{[0.891]}\end{array}$ \\
\hline Adj. R-Square & 0.373 & 0.497 & 0.604 & 0.870 & 0.906 & 0.761 & 0.112 & 0.174 \\
\hline Observations & 4791 & 4791 & 4792 & 4314 & 1605 & 4837 & 4866 & 4914 \\
\hline Countries & 175 & 175 & 175 & 164 & 87 & 175 & 175 & 174 \\
\hline
\end{tabular}




\begin{tabular}{|c|c|c|c|c|c|c|c|c|}
\hline $\begin{array}{l}\text { All countries, main specification, } \\
\text { with elections }\end{array}$ & Fiscal balance & Revenue & Expenditure & Gross debt & Net debt & $\begin{array}{l}\text { Reserves to } \\
\text { GDP }\end{array}$ & GDP growth & NEER change \\
\hline L.Overall fiscal balance, $\%$ of GDP & $\begin{array}{c}0.540^{* * * *} \\
{[0.104]}\end{array}$ & & & & & & & \\
\hline Annual world real GDP growth, percent & $\begin{array}{l}0.389^{* * * *} \\
{[0.141]}\end{array}$ & $\begin{array}{l}0.0945 \\
{[0.128]}\end{array}$ & $\begin{array}{l}-0.276^{* * * *} \\
{[0.0761]}\end{array}$ & $\begin{array}{c}0.206 \\
{[0.313]}\end{array}$ & $\begin{array}{l}-0.354 \\
{[0.297]}\end{array}$ & $\begin{array}{l}-0.280 \\
{[0.231]}\end{array}$ & $\begin{array}{c}0.714^{* * * *} \\
{[0.121]}\end{array}$ & $\begin{array}{c}0.319^{*} \\
{[0.188]}\end{array}$ \\
\hline Standardized VIX & $\begin{array}{l}-0.245^{* * *} \\
{[0.0732]}\end{array}$ & $\begin{array}{c}-0.266^{* * * *} \\
{[0.0658]}\end{array}$ & $\begin{array}{c}0.0766 \\
{[0.0739]}\end{array}$ & $\begin{array}{l}1.502^{* * * * *} \\
{[0.332]}\end{array}$ & $\begin{array}{l}0.588^{* *} \\
{[0.267]}\end{array}$ & $\begin{array}{l}-0.179 \\
{[0.179]}\end{array}$ & $\begin{array}{l}-0.0843 \\
{[0.106]}\end{array}$ & $\begin{array}{l}0.0877 \\
{[0.200]}\end{array}$ \\
\hline Commodity export price change, normalized & $\begin{array}{l}-0.0348 \\
{[0.183]}\end{array}$ & $\begin{array}{c}-0.00691 \\
{[0.150]}\end{array}$ & $\begin{array}{c}-0.00490 \\
{[0.112]}\end{array}$ & $\begin{array}{l}-0.349 \\
{[0.298]}\end{array}$ & $\begin{array}{c}0.619 \\
{[0.471]}\end{array}$ & $\begin{array}{l}-0.0740 \\
{[0.0902]}\end{array}$ & $\begin{array}{c}0.125 \\
{[0.0918]}\end{array}$ & $\begin{array}{l}0.555^{* *} \\
{[0.254]}\end{array}$ \\
\hline $\begin{array}{l}\text { Commodity export price change, normalized } \mathrm{x} \\
\text { exporter }\end{array}$ & $\begin{array}{l}1.299^{* * * *} \\
{[0.326]}\end{array}$ & $\begin{array}{l}0.669^{* * *} \\
{[0.232]}\end{array}$ & $\begin{array}{c}-0.665^{* * *} \\
{[0.226]}\end{array}$ & $\begin{array}{l}-2.797^{* *} \\
{[1.164]}\end{array}$ & $\begin{array}{l}-2.420 \\
{[1.690]}\end{array}$ & $\begin{array}{l}-0.236 \\
{[0.255]}\end{array}$ & $\begin{array}{l}0.247 \\
{[0.191]}\end{array}$ & -0.0967 \\
\hline Commodity import price change, normalized & $\begin{array}{c}0.390 \\
{[0.255]}\end{array}$ & $\begin{array}{c}0.251 \\
{[0.281]}\end{array}$ & $\begin{array}{l}0.0345 \\
{[0.173]}\end{array}$ & $\begin{array}{l}-0.616 \\
{[0.796]}\end{array}$ & $\begin{array}{l}-0.701 \\
{[0.809]}\end{array}$ & $\begin{array}{l}0.0932 \\
{[0.296]}\end{array}$ & $\begin{array}{l}0.0761 \\
{[0.217]}\end{array}$ & $\begin{array}{c}-1.200^{* * * * *} \\
{[0.334]}\end{array}$ \\
\hline $\begin{array}{l}\text { Commodity import price change, normalized } \mathrm{x} \\
\text { importer }\end{array}$ & $\begin{array}{l}-0.405 \\
{[0.292]}\end{array}$ & $\begin{array}{l}-0.254 \\
{[0.312]}\end{array}$ & $\begin{array}{l}-0.0385 \\
{[0.207]}\end{array}$ & $\begin{array}{l}-0.590 \\
{[0.970]}\end{array}$ & $\begin{array}{c}0.111 \\
{[0.985]}\end{array}$ & $\begin{array}{l}-0.773^{* *} \\
{[0.380]}\end{array}$ & $\begin{array}{l}-0.0659 \\
{[0.205]}\end{array}$ & $\begin{array}{c}0.679^{*} \\
{[0.385]}\end{array}$ \\
\hline $\begin{array}{l}\text { US government } 10 \text {-year constant maturity bond yield, } \\
\text { percent }\end{array}$ & $\begin{array}{c}0.153^{* *} \\
{[0.0706]}\end{array}$ & $\begin{array}{c}-0.337^{* * * *} \\
{[0.0773]}\end{array}$ & $\begin{array}{l}-0.328^{* * * *} \\
{[0.0507]}\end{array}$ & $\begin{array}{l}-0.175 \\
{[0.177]}\end{array}$ & $\begin{array}{l}-0.830^{* * * *} \\
{[0.205]}\end{array}$ & $\begin{array}{l}-0.0258 \\
{[0.0981]}\end{array}$ & $\begin{array}{c}0.186^{* *} \\
{[0.0744]}\end{array}$ & $\begin{array}{l}-0.283^{* *} \\
{[0.121]}\end{array}$ \\
\hline Transition year dummy, from PolityIV & $\begin{array}{l}-4.532 \\
{[2.775]}\end{array}$ & $\begin{array}{l}-1.629^{* *} \\
{[0.768]}\end{array}$ & $\begin{array}{l}2.336 \\
{[2.105]}\end{array}$ & $\begin{array}{l}13.54^{* * * *} \\
{[4.676]}\end{array}$ & $\begin{array}{c}17.50^{*} \\
{[10.11]}\end{array}$ & $\begin{array}{l}6.275 \\
{[5.887]}\end{array}$ & $\begin{array}{l}-4.556 \\
{[2.964]}\end{array}$ & $\begin{array}{l}-1.316 \\
{[1.416]}\end{array}$ \\
\hline Systemic banking crisis from Laeven-Valencia & $\begin{array}{l}-0.366 \\
{[0.478]}\end{array}$ & $\begin{array}{l}-0.0907 \\
{[0.330]}\end{array}$ & $\begin{array}{c}0.382 \\
{[0.524]}\end{array}$ & $\begin{array}{l}7.901^{* * * *} \\
{[2.682]}\end{array}$ & $\begin{array}{l}2.210 \\
{[2.538]}\end{array}$ & $\begin{array}{l}-1.202^{* *} \\
{[0.592]}\end{array}$ & $\begin{array}{c}-1.681^{* * *} \\
{[0.507]}\end{array}$ & $\begin{array}{l}-2.369 \\
{[1.628]}\end{array}$ \\
\hline Log population, deviation from quadratic trend & $\begin{array}{l}-0.0256 \\
{[0.0361]}\end{array}$ & $\begin{array}{l}0.000814 \\
{[0.0278]}\end{array}$ & $\begin{array}{c}0.0361^{*} \\
{[0.0207]}\end{array}$ & $\begin{array}{c}0.0216 \\
{[0.0856]}\end{array}$ & $\begin{array}{l}-0.0875 \\
{[0.129]}\end{array}$ & $\begin{array}{l}0.00352 \\
{[0.0284]}\end{array}$ & $\begin{array}{l}-0.0475 \\
{[0.0377]}\end{array}$ & $\begin{array}{r}-0.00557 \\
{[0.0496]}\end{array}$ \\
\hline $\begin{array}{l}\text { Log population, deviation, interacted with advanced } \\
\text { dummy }\end{array}$ & $\begin{array}{c}-0.341^{* *} \\
{[0.168]}\end{array}$ & $\begin{array}{l}0.0769 \\
{[0.102]}\end{array}$ & $\begin{array}{l}0.288^{* *} \\
{[0.117]}\end{array}$ & $\begin{array}{c}0.961^{*} \\
{[0.497]}\end{array}$ & $\begin{array}{c}0.824^{*} \\
{[0.484]}\end{array}$ & $\begin{array}{l}0.0748 \\
{[0.156]}\end{array}$ & $\begin{array}{c}-0.367^{* *} \\
{[0.162]}\end{array}$ & $\begin{array}{c}-0.169 \\
{[0.190]}\end{array}$ \\
\hline Damages from natural disasters, USD bn & $\begin{array}{l}-0.202 \\
{[0.221]}\end{array}$ & $\begin{array}{c}0.138 \\
{[0.130]}\end{array}$ & $\begin{array}{l}0.307^{* *} \\
{[0.149]}\end{array}$ & $\begin{array}{c}0.683 \\
{[0.556]}\end{array}$ & $\begin{array}{l}1.155^{* *} \\
{[0.444]}\end{array}$ & $\begin{array}{c}0.292 \\
{[0.254]}\end{array}$ & $\begin{array}{l}-0.581^{* * *} \\
{[0.270]}\end{array}$ & $\begin{array}{l}0.923^{* *} \\
{[0.419]}\end{array}$ \\
\hline Damages from natural disasters $\mathrm{x} \log$ population & $\begin{array}{c}0.0103 \\
{[0.0116]}\end{array}$ & $\begin{array}{c}-0.00745 \\
{[0.00681]}\end{array}$ & $\begin{array}{l}-0.0160^{* *} \\
{[0.00780]}\end{array}$ & $\begin{array}{c}-0.0332 \\
{[0.0292]}\end{array}$ & $\begin{array}{l}-0.0596^{* *} \\
{[0.0232]}\end{array}$ & $\begin{array}{c}-0.0152 \\
{[0.0134]}\end{array}$ & $\begin{array}{l}0.0302^{* *} \\
{[0.0142]}\end{array}$ & $\begin{array}{l}-0.0479^{* *} \\
{[0.0220]}\end{array}$ \\
\hline Election year dummy & $\begin{array}{l}-0.387^{* *} \\
{[0.174]}\end{array}$ & $\begin{array}{c}-0.115 \\
{[0.125]}\end{array}$ & $\begin{array}{l}0.263^{* *} \\
{[0.129]}\end{array}$ & $\begin{array}{c}0.392 \\
{[0.468]}\end{array}$ & $\begin{array}{c}0.282 \\
{[0.450]}\end{array}$ & $\begin{array}{l}-0.0398 \\
{[0.197]}\end{array}$ & $\begin{array}{l}-0.0592 \\
{[0.171]}\end{array}$ & $\begin{array}{c}0.100 \\
{[0.293]}\end{array}$ \\
\hline L.Overall government revenue, $\%$ of GDP & & $\begin{array}{c}0.591^{* * * *} \\
{[0.104]}\end{array}$ & & & & & & \\
\hline L.Overall government expenditure, $\%$ of GDP & & & $\begin{array}{l}0.791^{* * * *} \\
{[0.0888]}\end{array}$ & & & & & \\
\hline L.Public debt, $\%$ of GDP, HPDD & & & & $\begin{array}{l}0.870^{* * * *} \\
{[0.0198]}\end{array}$ & & & & \\
\hline L.General govt net debt, $\%$ of GDP & & & & & $\begin{array}{l}0.940^{* * * *} \\
{[0.0116]}\end{array}$ & & & \\
\hline L.International reserves, $\%$ of USD GDP, EWN & & & & & & $\begin{array}{c}0.955^{* * * *} \\
{[0.108]}\end{array}$ & & \\
\hline L.Annual real GDP growth, percent & & & & & & & $\begin{array}{c}0.167^{* *} \\
{[0.0657]}\end{array}$ & \\
\hline $\begin{array}{l}\text { L.Change in the nominal effective exchange rate, } \\
\text { percent }\end{array}$ & & & & & & & & $\begin{array}{l}0.222^{* * * *} \\
{[0.0294]}\end{array}$ \\
\hline Constant & $\begin{array}{c}-2.814^{* * * *} \\
{[0.766]}\end{array}$ & $\begin{array}{c}12.92^{* * * *} \\
{[2.843]}\end{array}$ & $\begin{array}{l}8.809^{* * *} \\
{[2.852]}\end{array}$ & $\begin{array}{l}6.220^{* * *} \\
{[1.979]}\end{array}$ & $\begin{array}{l}5.809^{* * *} \\
{[1.832]}\end{array}$ & $\begin{array}{c}2.488 \\
{[1.809]}\end{array}$ & $\begin{array}{l}-0.0869 \\
{[0.511]}\end{array}$ & $\begin{array}{l}-1.285^{*} \\
{[0.758]}\end{array}$ \\
\hline Adj. R-Square & 0.304 & 0.363 & 0.607 & 0.856 & 0.898 & 0.719 & 0.126 & 0.0922 \\
\hline Observations & 3494 & 3494 & 3494 & 3179 & 1453 & 3500 & 3502 & 3512 \\
\hline Countries & 170 & 170 & 170 & 158 & 86 & 170 & 170 & 169 \\
\hline
\end{tabular}




\section{System GMM Arellano-Bond bias correction}

While most of our specifications include relatively long panels (with 30 years of data on average per countries), we may still want to correct issues related to the presence of systematic endogeneity bias in dynamic panel data, since (within) error terms in fixed-effects regressions are mechanically correlated with lags of explanatory variables. The high estimated persistence of most fiscal outcomes, notably the overall fiscal balance, debt, expenditure and revenue to GDP ratios, suggests using bias-corrected estimators. To this end, we implement the Arellano-Bond system-GMM approach of instrumenting lagged variables with further lags (that differ for each time period, using all possible available lags for each time period and estimating coefficients via a system GMM approach where all orthogonality conditions with respect to lagged levels of the dependent variables are included). While the estimated auto-correlation coefficients on the fiscal outcome variables are slightly affected and reduced for most coefficients by this approach relative to the standard panel regression approach, most of the estimated coefficients of interest on exogenous variables remain similar in sign and magnitude to the main specifications. $^{13}$

\footnotetext{
13 The same robustness holds for the post-1995 sample including election data, results are available upon request.
} 


\begin{tabular}{|c|c|c|c|c|c|c|c|c|}
\hline All countries, Arellano-Bond & $\begin{array}{c}\text { Fiscal } \\
\text { balance }\end{array}$ & Revenue & Expenditure & Gross debt & Net debt & $\begin{array}{l}\text { Reserves to } \\
\text { GDP }\end{array}$ & GDP growth & $\begin{array}{l}\text { NEER } \\
\text { change }\end{array}$ \\
\hline L. Overall fiscal balance, $\%$ of GDP & $\begin{array}{l}0.582^{* * * *} \\
{[0.0849]}\end{array}$ & & & & & & & \\
\hline Annual world real GDP growth, percent & $\begin{array}{l}0.365^{* * *} \\
0.130]\end{array}$ & $\begin{array}{c}0.132 \\
{[0.102]}\end{array}$ & $\begin{array}{c}-0.346^{* * * *} \\
{[0.0954]}\end{array}$ & $\begin{array}{l}-2.188^{* *} \\
{[0.914]}\end{array}$ & $\begin{array}{l}-0.677^{*} \\
{[0.378]}\end{array}$ & $\begin{array}{l}-0.235^{* * *} \\
{[0.0817]}\end{array}$ & $\begin{array}{l}0.709^{* * * *} \\
{[0.0842]}\end{array}$ & $\begin{array}{l}-0.157 \\
{[0.266]}\end{array}$ \\
\hline Standardized VIX & $\begin{array}{c}-0.267^{* * *} \\
{[0.100]}\end{array}$ & $\begin{array}{l}-0.224^{* * *} \\
{[0.0765]}\end{array}$ & $\begin{array}{l}-0.0545 \\
{[0.0999]}\end{array}$ & $\begin{array}{l}-1.312 \\
{[1.119]}\end{array}$ & $\begin{array}{c}0.166 \\
{[0.311]}\end{array}$ & $\begin{array}{c}-0.161^{*} \\
{[0.0924]}\end{array}$ & $\begin{array}{c}-0.123 \\
{[0.0793]}\end{array}$ & $\begin{array}{l}-0.411 \\
{[0.265]}\end{array}$ \\
\hline Commodity export price change, normalized & $\begin{array}{l}0.00756 \\
{[0.107]}\end{array}$ & $\begin{array}{l}-0.118 \\
{[0.102]}\end{array}$ & $\begin{array}{l}-0.208 \\
{[0.136]}\end{array}$ & $\begin{array}{l}-0.450 \\
{[0.392]}\end{array}$ & $\begin{array}{l}0.0928 \\
{[0.493]}\end{array}$ & $\begin{array}{l}-0.140 \\
{[0.146]}\end{array}$ & $\begin{array}{l}0.0129 \\
{[0.104]}\end{array}$ & $\begin{array}{l}0.572^{* *} \\
{[0.223]}\end{array}$ \\
\hline $\begin{array}{l}\text { Commodity export price change, normalized } \mathrm{x} \\
\text { exporter }\end{array}$ & $\begin{array}{l}1.469^{* * * *} \\
{[0.404]}\end{array}$ & $\begin{array}{c}0.792^{* * * *} \\
{[0.232]}\end{array}$ & $\begin{array}{l}-0.491^{* *} \\
{[0.250]}\end{array}$ & $\begin{array}{l}-0.328 \\
{[0.878]}\end{array}$ & $\begin{array}{l}-2.725 \\
{[1.680]}\end{array}$ & -0.0151 & {$[0.318$} & $\begin{array}{c}0.160 \\
{[0.621]}\end{array}$ \\
\hline Commodity import price change, normalized & $\begin{array}{l}0.692^{* * *} \\
{[0.242]}\end{array}$ & $\begin{array}{c}0.233 \\
{[0.270]}\end{array}$ & $\begin{array}{l}-0.126 \\
{[0.174]}\end{array}$ & $\begin{array}{l}-1.495 \\
{[1.175]}\end{array}$ & $\begin{array}{l}-0.573 \\
{[0.817]}\end{array}$ & $\begin{array}{c}0.130 \\
{[0.307]}\end{array}$ & $\begin{array}{c}-0.00504 \\
{[0.224]}\end{array}$ & $\begin{array}{l}-0.216 \\
{[0.568]}\end{array}$ \\
\hline $\begin{array}{l}\text { Commodity import price change, normalized } \mathrm{x} \\
\text { importer }\end{array}$ & $\begin{array}{l}-0.695^{* *} \\
{[0.289]}\end{array}$ & $\begin{array}{l}-0.316 \\
{[0.301]}\end{array}$ & $\begin{array}{c}0.212 \\
{[0.235]}\end{array}$ & $\begin{array}{c}1.231 \\
{[1.022]}\end{array}$ & $\begin{array}{c}0.567 \\
{[0.897]}\end{array}$ & $\begin{array}{l}-0.610 \\
{[0.394]}\end{array}$ & {$[0.128$} & $\begin{array}{c}0.599 \\
{[0.577]}\end{array}$ \\
\hline $\begin{array}{l}\text { US government } 10 \text {-year constant maturity bond yield, } \\
\text { percent }\end{array}$ & $\begin{array}{l}-0.0399 \\
{[0.0876]}\end{array}$ & $\begin{array}{l}-0.164^{*} \\
{[0.0873]}\end{array}$ & $\begin{array}{l}-0.228^{* * * *} \\
{[0.0576]}\end{array}$ & $\begin{array}{l}5.356^{* *} \\
{[2.443]}\end{array}$ & $\begin{array}{l}-0.272 \\
{[0.252]}\end{array}$ & $-0.296^{*}$ & $\begin{array}{l}0.187^{* *} \\
{[0.0765]}\end{array}$ & $\begin{array}{c}-0.975^{* * *} \\
{[0.366]}\end{array}$ \\
\hline Transition year dummy, from PolityIV & $\begin{array}{l}-2.081^{* *} \\
{[0.840]}\end{array}$ & $\begin{array}{l}-2.519^{* *} \\
{[1.079]}\end{array}$ & $\begin{array}{l}0.408 \\
{[0.697]}\end{array}$ & $24.23^{* *}$ & $\begin{array}{l}26.93^{*} \\
{[15.67]}\end{array}$ & $\begin{array}{c}3.310 \\
{[4.472]}\end{array}$ & $\begin{array}{l}-2.251 \\
{[2.029]}\end{array}$ & $\begin{array}{l}-0.203 \\
{[1.549]}\end{array}$ \\
\hline Systemic banking crisis from Laeven-Valencia & $\begin{array}{l}-0.163 \\
{[0.460]}\end{array}$ & $\begin{array}{l}-0.0900 \\
{[0.346]}\end{array}$ & $\begin{array}{c}0.612 \\
{[0.544]}\end{array}$ & $\begin{array}{l}4.844^{* *} \\
{[2.429]}\end{array}$ & $\begin{array}{c}2.346 \\
{[2.498]}\end{array}$ & $\begin{array}{l}-0.810 \\
{[0.500]}\end{array}$ & $\begin{array}{c}-1.504^{* * *} \\
{[0.490]}\end{array}$ & $\begin{array}{l}-1.086 \\
{[1.663]}\end{array}$ \\
\hline Log population, deviation from quadratic trend & $\begin{array}{l}-0.0598 \\
{[0.0552]}\end{array}$ & $\begin{array}{l}0.00981 \\
{[0.0303]}\end{array}$ & $\begin{array}{l}-0.0623 \\
{[0.0880]}\end{array}$ & $\begin{array}{l}-0.893 \\
{[0.590]}\end{array}$ & $\begin{array}{c}0.177 \\
{[0.230]}\end{array}$ & $\begin{array}{l}-0.00625 \\
{[0.0437]}\end{array}$ & $\begin{array}{l}-0.00374 \\
{[0.0353]}\end{array}$ & $\begin{array}{c}0.0650 \\
{[0.111]}\end{array}$ \\
\hline $\begin{array}{l}\text { Log population, deviation, interacted with advanced } \\
\text { dummy }\end{array}$ & $\begin{array}{l}-0.0873 \\
{[0.270]}\end{array}$ & $\begin{array}{c}0.114 \\
{[0.223]}\end{array}$ & $\begin{array}{l}0.414^{* *} \\
{[0.209]}\end{array}$ & $\begin{array}{c}0.691 \\
{[1.064]}\end{array}$ & $\begin{array}{l}1.228^{* *} \\
{[0.494]}\end{array}$ & $\begin{array}{c}0.434^{*} \\
{[0.240]}\end{array}$ & $\begin{array}{c}-0.727^{* * *} \\
{[0.267]}\end{array}$ & $\begin{array}{c}0.873 \\
{[0.622]}\end{array}$ \\
\hline Damages from natural disasters, USD bn & $\begin{array}{c}-0.181 \\
{[0.121]}\end{array}$ & $\begin{array}{l}-0.0273 \\
{[0.177]}\end{array}$ & $\begin{array}{c}0.0402 \\
{[0.124]}\end{array}$ & $\begin{array}{c}0.800 \\
{[0.814]}\end{array}$ & $\begin{array}{c}1.648^{* * * *} \\
{[0.469]}\end{array}$ & $\begin{array}{c}0.132 \\
{[0.160]}\end{array}$ & $\begin{array}{c}-0.436 \\
{[0.302]}\end{array}$ & $\begin{array}{c}0.501 \\
{[0.346]}\end{array}$ \\
\hline Damages from natural disasters $\mathrm{x} \log$ population & $\begin{array}{c}0.00935 \\
{[0.00615]}\end{array}$ & $\begin{array}{c}0.00139 \\
{[0.00943]}\end{array}$ & $\begin{array}{c}-0.00162 \\
{[0.00650]}\end{array}$ & $\begin{array}{c}-0.0367 \\
{[0.0421]}\end{array}$ & $\begin{array}{c}-0.0855^{* * * *} \\
{[0.0248]}\end{array}$ & $\begin{array}{l}-0.00656 \\
{[0.00830]}\end{array}$ & $\begin{array}{c}0.0223 \\
{[0.0160]}\end{array}$ & $\begin{array}{l}-0.0252 \\
{[0.0180]}\end{array}$ \\
\hline L.Overall government revenue, $\%$ of GDP & & $\begin{array}{c}0.455^{* * * *} \\
{[0.125]}\end{array}$ & & & & & & \\
\hline L.Overall government expenditure, $\%$ of GDP & & & $\begin{array}{l}0.746^{* * * *} \\
{[0.0630]}\end{array}$ & & & & & \\
\hline L.Public debt, $\%$ of GDP, HPDD & & & & $\begin{array}{l}0.443^{* *} \\
{[0.190]}\end{array}$ & & & & \\
\hline L.General govt net debt, \% of GDP & & & & & $\begin{array}{l}0.936^{* * * *} \\
{[0.0114]}\end{array}$ & & & \\
\hline L.International reserves, $\%$ of USD GDP, EWN & & & & & & $\begin{array}{l}0.808^{* * * *} \\
{[0.0488]}\end{array}$ & & \\
\hline L.Annual real GDP growth, percent & & & & & & & $\begin{array}{c}0.123 \\
{[0.118]}\end{array}$ & \\
\hline $\begin{array}{l}\text { L.Change in the nominal effective exchange rate, } \\
\text { percent }\end{array}$ & & & & & & & & $\begin{array}{l}0.451^{* * * *} \\
{[0.0363]}\end{array}$ \\
\hline Observations & 4629 & 4629 & 4630 & 4120 & 1518 & 4675 & 4702 & 4747 \\
\hline
\end{tabular}

Standard errors in brackets

${ }^{*} p<0.10,{ }^{* *} p<0.05,{ }^{* * *} p<0.01,{ }^{* * * *} p<0.001$ 


\section{ESTIMATING THE IMPACT OF DOMESTIC GROWTH}

This section aims at assessing the fiscal impact of domestic growth, by employing our two main econometric methods (local projections and standard panel regressions), but applying instrumental variables.

\section{i. Linear Projection-IV method}

To compute the dynamic response of the fiscal deficit to domestic shocks at different horizons, net of the endogeneity effects of fiscal variables onto such domestic shocks, we use a two-step instrumental variable linear projection methods (LP-IV), inspired from recent work by Jorda et al. (2018), Stock and Watson (2018), and Jaimovich and Panizza (2007). Domestic variables are predicted from a first-stage regression on plausibly exogenous instruments, i.e. world growth interacted with trade openness, which provides a valid instrument under the assumption that the impact of such shock on domestic fiscal outcomes is channeled through domestic GDP growth.

We then implement the method of local linear projections with instrumental variables by regressing multiple steps-ahead outcome fiscal variables on instrumented domestic GDP growth. Essentially, we estimate the following system, for $\boldsymbol{h}=(\mathbf{0}, \mathbf{1}, \ldots, \mathbf{4})$, where $\boldsymbol{D}$ is the variable of interest, $\boldsymbol{X}_{i t}^{\boldsymbol{D}}$ a set of $\boldsymbol{D}$-specific control variables, and $\boldsymbol{A}_{\boldsymbol{y}}^{\boldsymbol{h}}, \boldsymbol{B}_{\boldsymbol{y}}^{\boldsymbol{h}}, \boldsymbol{\beta}_{\boldsymbol{h}}(\boldsymbol{L}), \boldsymbol{A}_{\boldsymbol{D}}(\boldsymbol{L}), \boldsymbol{\gamma}(\boldsymbol{L})$, $\boldsymbol{B}_{\boldsymbol{D}}(\boldsymbol{L})$ are flexible lag polynomials, and $\boldsymbol{\beta}_{\boldsymbol{h}}(\mathbf{0})$ is a coefficient of interest:

$$
\begin{gathered}
y_{i t+h}-y_{i t-1}=\alpha_{i}+A^{h}(L) \Delta y_{i, t-1}+\beta_{h}(L) D_{i t}+B^{h}(L) X_{i t}^{D}+\varepsilon_{i t, h} \\
D_{i t}=\alpha_{i}+A_{D}(L) \Delta y_{i, t-1}+\gamma(L) Z_{i t}+B_{D}(L) X_{i t}+v_{i t}
\end{gathered}
$$

where $Z_{i t}$ is a set of instruments for $D_{i t}$ satisfying the two traditional conditions of relevance:

and exogeneity:

$$
\operatorname{Cov}\left(\gamma(L) Z_{i t}, D_{i t} \mid B_{D}(L) X_{i t}, A_{D}(L) \Delta y_{i, t-1}\right) \neq 0 \forall i, t
$$

$$
\operatorname{Cov}\left(\gamma(L) Z_{i t}, \varepsilon_{i t h} \mid B_{y}(L) X_{i t}, A_{y}^{h}(L) \Delta y_{i, t-1}\right)=0 \forall h, i, t
$$

As in the traditional local projection approach of the previous sub-section, we include country fixed effects and use robust standard errors corrected for heteroskedasticity across countries.

Domestic growth appears to have a strong positive impact on the fiscal balance. The effect is significantly stronger and more persistent in emerging economies, where a one percentage point increase in real GDP growth improves the fiscal balance by around 1 percentage point of GDP on impact, relative to a 0.5 percentage points of GDP impact in advanced economies. The initial negative effect on expenditure to GDP ratios is similar, at around 0.5 percentage points of GDP, in advanced and emerging economies, while revenue to GDP ratios are virtually unchanged in advanced countries, while they rise by about 0.5 percentage points in emerging countries. 
Domestic growth shocks persist over time in emerging economies, but dwindle after one year in advanced economies, consistent with the hypothesis (see Aguiar, Gopinath, 2007) that GDP shocks in emerging economies are "trend shocks" while they are more transitory in advanced economies. This different GDP persistence, as well as the larger fiscal balance impact in emerging countries, leads to a much more significant reduction in debt to GDP ratios over time in emerging economies, by close to 4 percent of GDP, than in advanced economies, where it is close to 1 percent after three years.

\section{Responses to 1 p.p. increase in domestic real GDP growth Emerging and developing vs Advanced}
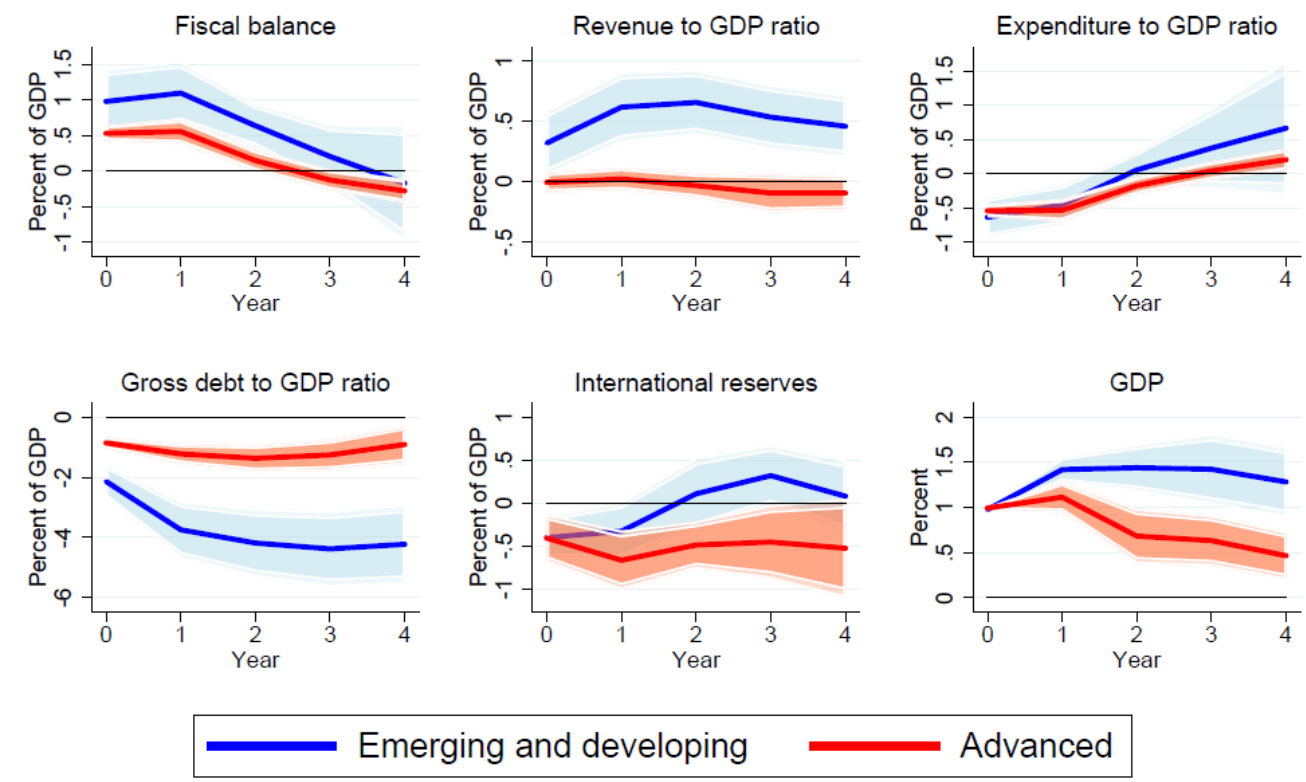

LP-IV method

\section{ii. Panel IV Estimates}

We then check the robustness of the LP-IV estimated medium-term responses to a more traditional panel dynamic instrumental variable estimation, using the same set of instruments for domestic real GDP growth. Essentially, we estimate the following system, where $y$ is the outcome variable, $D$ is the variable of interest, $X^{D}$ a set of $D$-specific control variables, and $\beta_{D}$ is a coefficient of interest:

$$
\begin{aligned}
& y_{i t}=\alpha_{y i}+\rho y_{i t-1}+\beta_{D} D_{i t}+\gamma X_{i t}^{D}+\varepsilon_{i t} \\
& D_{i t}=\alpha_{D i}+\rho_{D} y_{i, t-1}+\pi Z_{i t}+\mu X_{i t}^{D}+v_{i t}
\end{aligned}
$$

$Z_{i t}$ is a set of instruments for $D_{i t}$ satisfying the two traditional conditions of relevance:

$$
\operatorname{Cov}\left(Z_{i t}, D_{i t} \mid y_{i, t-1}, X_{i t}\right) \neq 0 \forall i, t
$$


and exogeneity:

$$
\operatorname{Cov}\left(Z_{i t}, \varepsilon_{i t} \mid y_{i, t-1}, X_{i t}\right)=0 \forall i, t
$$

The results again suggest that domestic growth tends to strongly improve the fiscal balance, by around $0.8 \%$ of GDP per additional point of domestic real GDP growth, in line with the linear-projection method results. This effect is divided between a decrease in expenditure to GDP around 0.5 percentage points of GDP, and a rise in revenue to GDP on impact of about 0.3 percentage points of GDP.

\begin{tabular}{|c|c|c|c|c|c|c|}
\hline \multicolumn{7}{|c|}{ All countries, IV for domestic growth } \\
\hline $\begin{array}{l}\text { Standard errors in brackets, }{ }^{*} p<0.10,{ }^{* *} p<0.05,{ }^{* * *} p< \\
0.01,{ }^{* * * *} p<0.001\end{array}$ & Fiscal balance & Revenue & Expenditure & Gross debt & Net debt & Reserves to GDP \\
\hline Annual real GDP growth, percent & $\begin{array}{l}0.756^{* * * *} \\
{[0.0700]}\end{array}$ & $\begin{array}{l}0.266^{* * * *} \\
{[0.0609]}\end{array}$ & $\begin{array}{c}-0.486^{* * * *} \\
{[0.0495]}\end{array}$ & $\begin{array}{c}-1.774^{* * * *} \\
{[0.186]}\end{array}$ & $\begin{array}{c}-0.986^{* * * *} \\
{[0.233]}\end{array}$ & $\begin{array}{c}-0.424^{* * * *} \\
{[0.100]}\end{array}$ \\
\hline L.Overall fiscal balance, $\%$ of GDP & $\begin{array}{l}0.595^{* * * * *} \\
{[0.0527]}\end{array}$ & & & & & \\
\hline L.Overall government revenue, $\%$ of GDP & & $\begin{array}{l}0.720^{* * * *} \\
{[0.0513]}\end{array}$ & & & & \\
\hline L.Overall government expenditure, $\%$ of GDP & & & $\begin{array}{l}0.770^{* * * *} \\
{[0.0344]}\end{array}$ & & & \\
\hline L.Public debt, $\%$ of GDP, HPDD & & & & $\begin{array}{l}0.919^{* * * *} \\
{[0.0160]}\end{array}$ & & \\
\hline L.General govt net debt, $\%$ of GDP & & & & & $\begin{array}{l}0.930^{* * * *} \\
{[0.0264]}\end{array}$ & \\
\hline L.International reserves, $\%$ of USD GDP, EWN & & & & & & $\begin{array}{l}0.881^{* * * *} \\
{[0.0326]}\end{array}$ \\
\hline Adj. R-Square & 0.160 & 0.508 & 0.547 & 0.866 & 0.917 & 0.714 \\
\hline Observations & 5667 & 5672 & 5668 & 5107 & 1805 & 5450 \\
\hline
\end{tabular}

Again similarly to the LP results, while the effect on expenditure is similar in AE and EMDC, the impact on revenue to GDP ratios is virtually zero in AE and is sizable in EMDC, leading to a smaller overall impact on the fiscal balance in AE (about 0.5 percent) than EMDC (about 0.8 percent). Gross debt to GDP drops by about 2.2 percent of GDP in emerging economies following a one percentage point domestic growth shocks, versus 0.9 percent in advanced economies.

\begin{tabular}{|c|c|c|c|c|c|c|}
\hline \multicolumn{7}{|c|}{ Advanced, IV for domestic growth } \\
\hline & Fiscal balance & Revenue & Expenditure & Gross debt & Net debt & Reserves to GDP \\
\hline Annual real GDP growth, percent & $\begin{array}{l}0.522^{* * * *} \\
{[0.0514]}\end{array}$ & $\begin{array}{c}0.0658 \\
{[0.0415]}\end{array}$ & $\begin{array}{c}-0.470^{* * * *} \\
{[0.0447]}\end{array}$ & $\begin{array}{c}-0.888^{* * * *} \\
{[0.0978]}\end{array}$ & $\begin{array}{c}-0.746^{* * * *} \\
{[0.109]}\end{array}$ & $\begin{array}{c}-0.391^{* * *} \\
{[0.146]}\end{array}$ \\
\hline L. Overall government revenue, $\%$ of GDP & & $\begin{array}{l}0.870^{* * * *} \\
{[0.0212]}\end{array}$ & & & & \\
\hline L.Overall government expenditure, $\%$ of GDP & & & $\begin{array}{l}0.812^{* * * *} \\
{[0.0218]}\end{array}$ & & & \\
\hline L.Public debt, $\%$ of GDP, HPDD & & & & $\begin{array}{c}0.961^{* * * *} \\
{[0.00907]}\end{array}$ & & \\
\hline L.General govt net debt, $\%$ of GDP & & & & & $\begin{array}{l}0.959^{* * * *} \\
{[0.0129]}\end{array}$ & \\
\hline L.International reserves, $\%$ of USD GDP, EWN & & & & & & $\begin{array}{l}0.964^{* * * *} \\
{[0.0203]}\end{array}$ \\
\hline Adj. R-Square & 0.557 & 0.782 & 0.792 & 0.961 & 0.950 & 0.873 \\
\hline
\end{tabular}




\begin{tabular}{|c|c|c|c|c|c|c|}
\hline \multicolumn{7}{|c|}{ Emerging, IV for domestic growth } \\
\hline & Fiscal balance & Revenue & Expenditure & Gross debt & Net debt & Reserves to GDP \\
\hline Annual real GDP growth, percent & $\begin{array}{l}0.798^{* * * * *} \\
{[0.0937]}\end{array}$ & $\begin{array}{l}0.331^{* * * * *} \\
{[0.0830]}\end{array}$ & $\begin{array}{c}-0.457^{* * * * *} \\
{[0.0658]}\end{array}$ & $\begin{array}{c}-2.233^{* * * * *} \\
{[0.269]}\end{array}$ & $\begin{array}{c}-1.235^{* * * *} \\
{[0.368]}\end{array}$ & $\begin{array}{c}-0.386^{* * * *} \\
{[0.112]}\end{array}$ \\
\hline L.Overall fiscal balance, $\%$ of GDP & $\begin{array}{l}0.589^{* * * *} \\
{[0.0575]}\end{array}$ & & & & & \\
\hline L.Overall government revenue, $\%$ of GDP & & $\begin{array}{l}0.706^{* * * *} \\
{[0.0542]}\end{array}$ & & & & \\
\hline L.Overall government expenditure, $\%$ of GDP & & & $\begin{array}{l}0.764^{* * * *} \\
{[0.0387]}\end{array}$ & & & \\
\hline L.Public debt, $\%$ of GDP, HPDD & & & & $\begin{array}{l}0.916^{* * * *} \\
{[0.0173]}\end{array}$ & & \\
\hline L.General govt net debt, $\%$ of GDP & & & & & $\begin{array}{l}0.923^{* * * *} \\
{[0.0306]}\end{array}$ & \\
\hline L.International reserves, $\%$ of USD GDP, EWN & & & & & & $\begin{array}{l}0.861^{* * * *} \\
{[0.0386]}\end{array}$ \\
\hline Adj. R-Square & 0.109 & 0.475 & 0.533 & 0.847 & 0.911 & 0.684 \\
\hline Observations & 4457 & 4462 & 4458 & 3975 & 1054 & 4311 \\
\hline
\end{tabular}

\section{THE FISCAL COST OF SHOCKS: A DISCUSSION OF STATE-CONTINGENCY}

\section{A. The Fiscal Cost of Shocks}

To summarize the fiscal cost of shocks, we provide in the table below a summary of the estimated impact of the key exogenous shocks at various horizons and for various subsamples, based on the coefficients of the local projection method (a table with the correlation across shocks is in Annex V). In bold we highlight significant estimates (where confidence bands reject the null of a zero effect with 90 percent confidence levels).

The impact on the fiscal balance is computed for all variables apart from dummies as the product of the coefficient (at horizon $\mathrm{h}$ ) from the local projections exercise times the withincountry standard deviation of the shock variable for a given subsample. For dummies, the impact is just offered by the coefficient.

Such an analysis offers the first step for designing contingent contracts or insurance mechanisms that can smooth the fiscal impact of exogenous shocks. Indeed, such contracts or mechanisms can be anchored to the shocks in order to deliver payments under certain conditions related to the occurrence of specific shocks, so that governments can use them to partially offset the fiscal impact of these shocks. Such an interesting analysis is left for future exploration.

The largest drivers of fiscal fluctuations in all countries are very rare events like political transitions and banking crisis, as well as global factors such as world growth, VIX, and commodity prices. For example, 3 years after the shock, debt to GDP of both AE and EMDC would increases by about 3 percentage points following a 1 standard deviation global growth shock, and by 5 percentage points following a VIX shock of similar magnitude. The effect would be much larger for a banking crisis or a political transition, and would be highly dependent on the type of country or of transition.

The fiscal impact measured in terms of the other main fiscal outcomes (expenditure and revenue, ratios) is reported in Annex VI. 
Table 1. Fiscal Cost of Shocks: Changes in Fiscal Balance Ratio to GDP

(one standard deviation shocks, apart from dummies; 90-percent significance in bold)

\begin{tabular}{|c|c|c|c|c|c|c|c|c|c|c|}
\hline $\begin{array}{c}\text { Fiscal } \\
\text { balance } \\
\text { impact }\end{array}$ & $\begin{array}{c}\text { World growth } \\
\text { (normalized } \\
\beta \times \sigma(\text { var }))\end{array}$ & $\begin{array}{l}\text { Goods terms-of- } \\
\text { trade change } \\
\text { (normalized } \\
\beta \times \sigma(\text { var }))\end{array}$ & $\begin{array}{l}\text { Commodity import } \\
\text { price change } \\
(\text { normalized } \\
\beta \times \sigma(\text { var }))\end{array}$ & $\begin{array}{l}\text { Commodity export } \\
\text { price change } \\
(\text { normalized } \\
\beta \times \sigma(\text { var }))\end{array}$ & $\begin{array}{c}\text { VIX } \\
\text { (normalized } \\
\beta \times \sigma(\text { var }))\end{array}$ & $\begin{array}{l}\text { US } 10 \text { year } \\
\text { yield } \\
\text { (normalized } \\
\beta \times \sigma(\text { var }))\end{array}$ & $\begin{array}{c}\text { Banking crisis } \\
\text { (dummy, } \beta \text { ) }\end{array}$ & $\begin{array}{c}\text { Transition } \\
\text { (dummy, } \beta \text { ) }\end{array}$ & $\begin{array}{c}\text { Population } \\
\text { (log deviation, } \\
\text { normalized } \\
\beta \times \sigma(\text { var }))\end{array}$ & $\begin{array}{c}\text { Election } \\
(\text { dummy, } \beta)\end{array}$ \\
\hline \multicolumn{11}{|l|}{ Year 0} \\
\hline All & 0.93 & 0.51 & -0.11 & 0.30 & -0.49 & -0.55 & -2.13 & -3.48 & -0.37 & -0.60 \\
\hline$E M$ & 093 & 0.61 & -0.04 & 0.38 & -0.52 & -0.77 & -191 & -3.44 & -0.76 & -0.78 \\
\hline$A E$ & 0.92 & 0.19 & -0.24 & 0.07 & -0.47 & 0.29 & -2.27 & & 0.02 & -0.11 \\
\hline$L A C$ & 0.66 & 0.48 & -0.21 & 0.33 & -0.31 & -0.03 & -1.86 & 0.86 & 6.60 & -0.16 \\
\hline \multicolumn{11}{|l|}{ Year 1} \\
\hline$A l l$ & 1.11 & -0.09 & -0.32 & 0.33 & -1.47 & 1.23 & -3.16 & -4.83 & 0.11 & -0.29 \\
\hline$E M$ & 1.08 & -0.23 & -0.22 & 0.42 & -1.47 & 1.14 & -1.70 & -4.75 & 0.53 & -0.35 \\
\hline$A E$ & 1.18 & 0.34 & -0.54 & 0.16 & -1.55 & 1.43 & -590 & & -0.74 & $-\mathbf{0 . 2 0}$ \\
\hline$L A C$ & 1.10 & 0.43 & -0.62 & 0.45 & -0.79 & -0.15 & -1.53 & 1.22 & 9.38 & 0.34 \\
\hline \multicolumn{11}{|l|}{ Year 2} \\
\hline All & 0.68 & 0.38 & -0.30 & 0.22 & -1.06 & 2.79 & -3.17 & -3.93 & -1.11 & -0.61 \\
\hline$E M$ & 0.69 & 0.42 & -0.20 & 0.29 & -0.98 & 2.94 & -1.29 & -3.78 & -0.81 & -0.86 \\
\hline$A E$ & 0.52 & 0.22 & -0.60 & 0.20 & -1.39 & 2.41 & -6.46 & & -1.30 & -0.08 \\
\hline$L A C$ & 0.67 & 0.36 & -0.60 & 0.57 & -0.64 & 1.02 & -0.71 & 0.40 & 12.89 & 0.09 \\
\hline \multicolumn{11}{|l|}{ Year 3} \\
\hline All & 0.44 & -0.03 & -0.50 & 0.21 & -0.40 & 2.34 & -2.29 & -3.73 & -1.60 & -0.35 \\
\hline$E M$ & 0.50 & -0.09 & -0.46 & 0.30 & -0.35 & 2.03 & -1.01 & -3.57 & -1.43 & -0.56 \\
\hline$A E$ & 0.18 & 0.10 & -0.59 & -0.22 & -0.53 & 3.06 & -3.80 & & -1.37 & -0.11 \\
\hline$L A C$ & 0.62 & 0.35 & -0.54 & 0.33 & -0.27 & 1.66 & -0.34 & -0.80 & 12.30 & -0.08 \\
\hline
\end{tabular}


Table 2. Fiscal Cost of Shocks: Changes in Debt Ratio to GDP

(one standard deviation shocks, apart from dummies; 90-percent significance in bold)

\begin{tabular}{|c|c|c|c|c|c|c|c|c|c|c|}
\hline Debt impact & $\begin{array}{c}\text { World growth } \\
\text { (normalized } \\
\beta \times \sigma(\text { var }))\end{array}$ & $\begin{array}{c}\text { Goods terms-of- } \\
\text { trade change } \\
\text { (normalized } \\
\beta \times \sigma(\text { var }))\end{array}$ & $\begin{array}{l}\text { Commodity import } \\
\text { price change } \\
\text { (normalized } \\
\beta \times \sigma(\text { var }))\end{array}$ & $\begin{array}{l}\text { Commodity export } \\
\text { price change } \\
\text { (normalized } \\
\beta \times \sigma(\text { var }))\end{array}$ & $\begin{array}{c}\text { VIX } \\
(\text { normalized } \\
\beta \times \sigma(\text { var }))\end{array}$ & $\begin{array}{c}\text { US } 10 \text { year } \\
\text { yield } \\
\text { (normalized } \\
\beta \times \sigma(\text { var }))\end{array}$ & $\begin{array}{l}\text { Banking crisis } \\
\text { (dummy, } \beta \text { ) }\end{array}$ & $\begin{array}{c}\text { Transition } \\
(\text { dummy, } \beta)\end{array}$ & $\begin{array}{c}\text { Population } \\
\text { (log deviation, } \\
\text { normalized } \\
\beta \times \sigma(\text { var }))\end{array}$ & $\begin{array}{c}\text { Election } \\
\text { (dummy, } \beta)\end{array}$ \\
\hline \multicolumn{11}{|c|}{ r } \\
\hline All & -1.78 & -0.77 & -0.17 & -1.00 & 0.99 & 1.00 & 4.86 & 6.44 & -0.60 & 0.50 \\
\hline$E M$ & -1.78 & -0.88 & -0.45 & -1.31 & 1.03 & 0.97 & 3.96 & 6.97 & 0.38 & 0.38 \\
\hline$A E$ & -1.82 & -0.27 & 0.74 & -0.20 & 1.15 & -0.28 & 6.78 & -0.16 & -0.09 & 0.50 \\
\hline$L A C$ & -2.42 & -0.86 & -0.01 & -1.03 & 1.39 & 2.32 & -4.77 & 2.97 & 16.97 & -0.70 \\
\hline \multicolumn{11}{|l|}{ Year 1} \\
\hline All & -2.88 & -1.14 & -0.79 & -1.49 & 4.09 & 0.66 & 7.22 & 12.14 & -2.70 & 0.66 \\
\hline$E M$ & -2.77 & -1.20 & -1.51 & -2.11 & 4.62 & 0.30 & 3.35 & 13.09 & -2.59 & 0.26 \\
\hline$A E$ & -3.21 & -0.60 & 1.77 & -0.32 & 2.99 & -1.31 & 15.66 & -0.66 & 1.76 & 1.28 \\
\hline$L A C$ & -5.21 & -1.15 & 0.30 & -2.44 & 6.25 & 4.84 & -1.98 & 12.12 & 28.55 & 0.12 \\
\hline \multicolumn{11}{|l|}{ Year 2} \\
\hline All & -3.09 & -1.57 & -1.25 & -1.44 & 5.14 & 2.34 & 9.75 & 13.47 & -1.95 & 1.09 \\
\hline$E M$ & -2.91 & -1.79 & -2.15 & -2.24 & 5.89 & 2.35 & 4.23 & 14.30 & -2.04 & 0.74 \\
\hline$A E$ & -332 & -0.46 & 2.17 & 0.02 & 3.76 & -2.40 & 21.57 & 0.41 & 4.05 & 1.36 \\
\hline$L A C$ & -635 & -1.76 & 0.11 & -2.56 & 8.14 & 3.01 & -0.36 & 18.80 & 30.27 & -0.58 \\
\hline \multicolumn{11}{|l|}{ Year 3} \\
\hline All & -3.04 & -1.27 & -1.49 & -1.84 & 4.58 & 3.37 & 10.89 & 15.25 & 1.05 & 1.62 \\
\hline$E M$ & -2.91 & -1.44 & -2.66 & -2.68 & 4.95 & 4.17 & 4.40 & 16.38 & 0.56 & 1.44 \\
\hline$A E$ & -3.46 & -0.21 & 2.58 & 0.70 & 3.97 & -4.27 & 25.27 & -3.98 & 7.26 & 0.94 \\
\hline$L A C$ & -6.52 & -2.31 & -0.68 & -2.03 & 7.73 & 6.73 & -5.89 & 23.78 & 38.95 & 0.30 \\
\hline
\end{tabular}




\section{B. State-Contingency Parameters for Public Debt}

Our estimates allow us to take a first pass at the potential for introducing state-contingency in debt contracts for sovereigns, along the lines of GDP indexed bonds. Domestic GDP growth has a significant, large, and persistent negative effect on debt to GDP ratio. This effect operates through a triple impact via an increase in the revenue ratio, a reduction in the expenditure ratio through a direct "denominator" effect from higher GDP, and a cumulative response of debt ratios both through an improved fiscal balance and a denominator effect.

In other words, our methodology takes into account not only the initial effect of GDP (say a decline) on debt ratios from an immediate denominator reduction, but also the persistence of the growth shocks (which would exacerbate the denominator effect), as well as the compounded effect of fiscal balance deterioration and

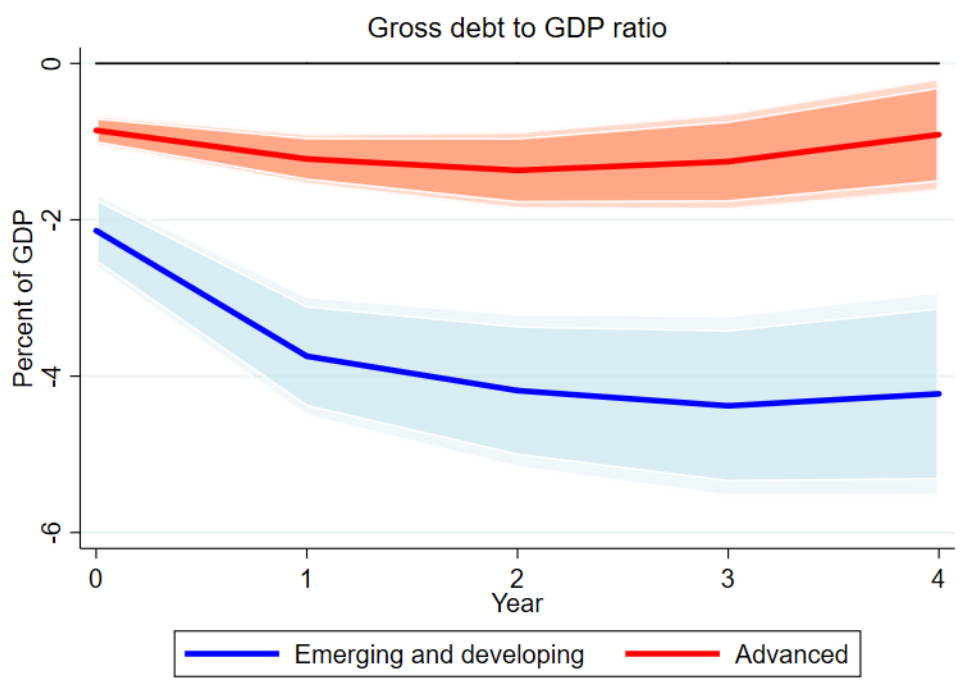
associated interest payment.

The analysis suggests that indexation parameters for possible state contingent debt to GDP would have to be much larger than 1 to stabilize debt ratios. In order to show this, let's relate our response coefficients on impact respectively for the debt to GDP ratio $D_{h} / Y_{h}$ to a real debt value elasticity to growth rate at horizon $h$, denoting the persistence of output growth at horizon $h$ by $\rho_{y, h}$ (note that $\rho_{y, 0}=1$ by construction):

$$
\widehat{\beta_{h, D} / Y}=\frac{d D_{h} / Y_{h}}{d g_{Y}}=\frac{d D_{h}}{d g_{Y}} \times \frac{1}{Y_{h}}-\frac{d Y_{h} / Y_{h}}{d g_{Y}} \times \frac{D_{h}}{Y_{h}} \approx\left[\frac{d D_{h} / D_{h}}{d g_{Y}}-\sum_{j=0}^{h} \rho_{y, j}\right] \times \frac{D_{h}}{Y_{h}}
$$

Therefore, using average debt to GDP ratios, we may translate the vector of coefficients at horizon $h$ obtained by LP IV estimation into real GDP growth-debt elasticities $\left(\frac{d^{D_{h}} / D_{h}}{d g_{Y}}=\eta_{T, h}\right)$, corresponding to the state-contingent reduction of the real debt value required to neutralize the overall effect of a percentage point growth shock on debt ratios.

Using, for the full sample:

$$
\eta_{D, h}{ }^{F U L L} \approx \frac{1}{D_{h} /_{h}} \times \widehat{\beta_{h, D}}+\sum_{j=0}^{h} \rho_{y, j}
$$

we find a $\eta_{D, 0}=-2 \%$ elasticity of the real level of debt on impact to a one percent growth shock, and close to a $\eta_{D, 1}=-3.8 \%$ impact after one year, stabilizing afterwards. Taken at 
face value, these estimates suggest that embedding state-contingency in sovereign debt contracts implies the need to offset a 4\% reduction after two years in the principal value of the debt for each $1 \%$ unexpected growth shock, in order to on average stabilize debt ratios in the medium-run. Similar computations yield numbers closer to $\eta_{D, 1}{ }^{A D V}=-1.2 \%$ elasticity of the real level of debt on impact to a one percent growth shock in advanced economies after two years, and close to a $\eta_{D, 1}{ }^{E M E}=-4.9 \%$ impact in emerging and developing economies, and $\eta_{D, 1}{ }^{L A C}=-3.7 \%$ in LAC countries, for the same shock and horizon.

\section{Variance Decomposition Exercise}

This section discusses key results from a variance decomposition exercise aimed at quantifying the relative importance of various sources of fluctuations of the fiscal deficit. Annex VII describes the methodology and report the graphs showing the results.

Most of the shocks analyzed tend to account for a smaller share of variation of fiscal balances in advanced economies than in emerging markets and developing countries. Also, the role of most shocks in explaining the variance of fiscal deficits tends to grow over time; the notable exception is the shock to global growth, whose role tends to decline after one year. It is remarkable that the most important shocks are the VIX (especially for countries with high financial openness) and commodity prices, in addition to global growth. When looking at a very preliminary decomposition of the relative contribution of expenditure and revenue shocks to the fiscal balance ratio, we find that the expenditure ratio is a much more important predictor of short-term fluctuations, and appears to play a relatively larger role in explaining forecast errors in emerging economies.

\section{CONCLUDing REMARKS}

This paper provides estimates of the sources of fluctuations in fiscal outcomes at various horizons, using a large panel dataset of about 140 countries over a period reaching up to 47 years. We explore heterogeneous, non-linear, dynamic responses of fiscal outcomes to various exogenous external and domestic shocks, across country groupings and various structural characteristics. Such a quantification could serve as an input for the exploration of the design and the potential cost of macroeconomic hedging strategies for sovereigns in future work.

Exogenous shocks create large temporary fluctuations in fiscal balances, both via revenues and expenditure, and their magnitude and persistence differ across groups and structural characteristics. World growth, financial risk appetite, political events, and commodity export prices are key determinants of fiscal balances in EMDC, while banking crises and import commodity prices appear to matter relatively more in AE.

More specifically:

- World growth or positive terms-of-trade shocks have a positive effect on the fiscal balance to GDP ratio, mainly via a lower expenditure ratio in AE and via a higher revenue ratio in EMDC, and tend to lower debt while increasing GDP. Commodity exporters highly benefit from an increase in commodity export prices, via higher 
revenue ratio, lower expenditure ratio (associated with higher GDP), and hence better fiscal balance and lower debt to GDP ratios.

- Global financial shocks, as measured by an increase in the VIX, tend to worsen the fiscal balance ratio via both lower revenue and higher expenditure ratios, as well as adversely affecting debt ratios and GDP.

- For EMDC, transition out of democracy, increase in military spending, or elections, tend to worsen the fiscal balance and debt ratios, mainly due to higher spending and lower GDP, and the size of the effect if different for each shock (declining in the order in which the three shocks are listed above); transition into democracy tend to have the opposite effect.

- A domestic banking crisis heavily worsens expenditure, revenue, fiscal balance and debt ratios, while adversely affecting GDP, and the effects are stronger in AE than EMDC.

- Population increases (relative to trend) are associated in advanced economies with persistent and significant deteriorations of the fiscal balance and debt ratios, mostly through higher expenditure ratios and lower GDP; in EMDC, the effect on GDP is positive, but both revenue and expenditure ratios decline, leaving the fiscal balance ratio roughly unchanged.

- Natural disasters worsen the fiscal balance and debt ratios as well as GDP, but mainly for smaller countries.

- Reserves increase substantially after favorable TOT shocks in EMDC, especially for commodity exporters, while they decline in EMDC and increase in AE after an adverse VIX shock (as capital shifts from EMDC towards safer heavens).

In terms of time profile, most exogenous shocks tend to generate a strong initial impact. Some tend to die-off over time (world growth) or persist (commodity prices or political shocks), while others generate an increasing effect with hump-shaped patterns over time (financial like VIX or banking crisis), peaking after one or two years. The impact of demographic shocks is instead limited initially and grows over time.

Overall, the effects on debt can be quite large. Three years after the shock, debt to GDP of both $\mathrm{AE}$ and EMDC would increases by about 3 percentage points following a 1 standard deviation global growth shock, and by 5 percentage points following a VIX shock of similar magnitude. The effect would be much larger for a banking crisis or a political transition, and would be highly dependent on the type of country or of transition.

Positive domestic growth shocks substantially improve the fiscal balance, mainly by lowering expenditure ratios, but also — in EMDC — by raising revenue ratios.

What are the key implications for macroeconomic insurance? First, global factors are relevant, suggesting that while countries would like the opportunity acquire insurance for global shocks, only small countries would be able to do so (the extent to which the private sector can insure large sovereigns can be debated). Second, fiscal outcomes react differentially to global factors across countries, suggesting there is room also for efficient risk-pooling across countries, and 
not only potential insurance between the public and private sectors. Third, domestic shocks are relevant, further highlighting the scope for risk pooling.

On the basis of the quantification of the effect of different shocks, the paper prepares the ground for exploring the design of contingent contracts or insurance mechanisms that could be used to smooth the fiscal impact of these shocks. An interesting example relates to the use of GDP-indexed bonds, which have often been discussed in the literature. Debt serves as a shock absorber, increasing after negative growth shocks and decreasing after positive surprises, suggesting market incompleteness and the potential for country insurance, for example (but not only) via GDP-indexed bonds: our estimates suggest that a one percentage point negative shock to domestic growth should be followed by about a $4 \%$ reduction in the value of the debt in the medium-term to stabilize debt ratios, on average. The need however is much smaller in advanced economies (about 1\%) than in emerging markets and developing countries (5\%). We also noted how reserves have different reaction to global factors (such as VIX) across country groups (AE and EMDC), and may also be easily insurable. Additional future work could be devoted to distinguishing the effects of automatic stabilizers and discretionary fiscal reactions to shocks (which would help assess to what extent discretionary policies can help absorb fiscal fluctuations), as well as to identifying existing financial instruments to hedge against exogenous shocks and to defining potential new optimal state-contingent debt contracts. 


\section{REFERENCES}

Abbas, S. A., Belhocine, N., El-Ganainy, A., \& Horton, M. (2011). Historical patterns and dynamics of public debt-evidence from a new database. IMF Economic Review, 59(4), 717-742.

Agnello, L., \& Sousa, R. M. (2009). The determinants of public deficit volatility, ECB Working Paper Series, n. 1042.

Aguiar, M., \& Gopinath, G. (2007). Emerging market business cycles: The cycle is the trend. Journal of political Economy, 115(1), 69-102.

Alberola, E., Kataryniuk, I., Melguizo, A., \& Orozco, R. (2016). Fiscal policy and the cycle in Latin America: the role of financing conditions and fiscal rules, Banco de España Working Paper No. 1604.

Alfaro, L. and F. Kanczuk (2005). "Sovereign debt as a contingent claim: a quantitative approach". In: Journal of International Economics 65.2, pp. 297-314.

Ang, A., Piazzesi, M., \& Wei, M. (2006). What does the yield curve tell us about GDP growth?. Journal of econometrics, 131(1-2), 359-403.

Angeletos, G. M. (2002). Fiscal policy with noncontingent debt and the optimal maturity structure. The Quarterly Journal of Economics, 117(3), 1105-1131.

Aslam, A., Beidas-Strom, S., Bems, R., Celasun, O., Çelik, S. K., \& Koczan, Z. (2016). Trading on Their Terms? Commodity Exporters in the Aftermath of the Commodity Boom. International Monetary Fund Working Paper 16-27.

Bali, T. G., Brown, S. J., \& Caglayan, M. O. (2014). Macroeconomic risk and hedge fund returns, Journal of Financial Economics, 114(1), 1-19.

Barr, D., O. Bush, and A. Pienkowski (2014). "GDP-linked bonds and sovereign default". In: Bank of England Working Paper 484.

Barro, R. J. (1979). On the determination of the public debt. Journal of political Economy, 87 (5, Part 1), 940-971.

Blanchard, O. (1990). Suggestions for a New Set of Fiscal Indicators. OECD Working Paper n. 79

Bohn, H. (1990). Tax smoothing with financial instruments. The American Economic Review, 1217-1230.

Borensztein, E. and P. Mauro (2002). "Reviving the case for GDP-indexed bonds". In: IMF Policy discussion paper 02/10.

Borensztein, E., Jeanne, O., \& Sandri, D. (2013). Macro-hedging for commodity exporters. Journal of Development Economics, 101, 105-116.

Brender, A., \& Drazen, A. (2005). Political budget cycles in new versus established democracies. Journal of monetary Economics, 52(7), 1271-1295.

Caballero, R. J., \& Panageas, S. (2008). Hedging sudden stops and precautionary contractions. Journal of Development Economics, 85(1-2), 28-57

Caballero, R. J., \& Panageas, S. (2004). Contingent reserves management: an applied framework, National Bureau of Economic Research Working Paper No. w10786.

Callen, M., Imbs, J. and Mauro P. (2015), Pooling risk across countries. Journal of International Economics, 96 (2015) 88-99

Canova, F., \& Ciccarelli, M. (2013). Panel Vector Autoregressive Models: A Survey, in VAR Models in Macroeconomics-New Developments and Applications: Essays in Honor of Christopher A. Sims (pp. 205-246). Emerald Group Publishing Limited. 
Cerovic, S., K. Gerling, A. Hodge, and P. Medas (2018), Predicting fiscal crises, IMF Working Paper 18/181

Crucini, M. (1998), On international and national dimensions of risk sharing, The Review of Economics and Statistics, February 1999, 81(1): 73-84

Cuadra, Gabriel and Horacio Sapriza (2008). "Sovereign default, interest rates and political uncertainty in emerging markets". In: Journal of International Economics 76.1, pp. 7888.

Durdu, Ceyhun Bora (2009). "Quantitative implications of indexed bonds in small open economies”. In: Journal of Economic Dynamics and control 33.4, pp. 883-902.

Em-dat, C. R. E. D. (2010). The OFDA/CRED international disaster database. Université catholique de Louvain.

Ghesquiere, F. and Mahul, O. (2007), Sovereign Natural Disaster Insurance for Developing Countries: A Paradigm Shift in Catastrophe Risk Financing, World Bank Policy Research Working Paper 4345

Gorodnichenko, Y., \& Lee, B. (2017). A Note on Variance Decomposition with Local Projections, National Bureau of Economic Research Working Paper No. w23998.

Gruss, B. (2014). After the boom-commodity prices and economic growth in Latin America and the Caribbean, International Monetary Fund Working Paper 14/154

Hadzi-Vaskov, M., \& Ricci, M. L. A. (2017). Does Gross or Net Debt Matter More for Emerging Market Spreads? International Monetary Fund Working Paper 16/246

Hatchondo, J. C. and L. Martinez (2012). "On the Benefits of GDP-Indexed Government Debt: Lessons from a Model of Sovereign Defaults”. Economic Quarterly 98.2, pp. 139-157.

Henzel, S. R., \& Rengel, M. (2017). Dimensions of macroeconomic uncertainty: A common factor analysis. Economic Inquiry, 55(2), 843-877.

Jaimovich, D. \& Panizza, U. (2007). Procyclicality or Reverse Causality? Inter-American Development Bank Working paper n. 599

Jorda, Oscar, Moritz Schularick, Alan M. Taylor (2018), The Effects of Quasi-Random

Monetary Experiments, Federal Reserve Bank of San Francisco Working Paper 2017-02

Jordà, Ò. (2005). Estimation and inference of impulse responses by local projections. American Economic Review, 95(1), 161-182.

Khandelwal, P., \& Roitman, A. (2013). The economics of political transitions: implications for the Arab Spring, International Monetary Fund Working Paper No. 13-69

Klemm, M. A. (2014). Fiscal policy in Latin America over the cycle. International Monetary Fund Working Paper (No. 14-59).

Laeven, M. L. \& Valencia, F. (2008). Systemic banking crises: a new database. International Monetary Fund Working Paper No. 8-224

Lane, Philip R. et Milesi-Ferretti, Gian Maria. The external wealth of nations mark II: Revised and extended estimates of foreign assets and liabilities, 1970-2004. Journal of international Economics, 2007, vol. 73, no 2, p. 223-250.

Lee, M., Bai, J., Zhang, F., \& Bachmann, R. (2014). The Welfare Costs of Fiscal Uncertainty: a Quantitative Evaluation. in 2014 Meeting Papers (No. 744). Society for Economic Dynamics.

Lusinyan, L., Cebotari, A., Velloso, R., Davis, J. M., Mati, A., Petrie, M., \& Mauro, P. (2009). Fiscal Risks; Sources, Disclosure, and Management. International Monetary Fund Working Paper No. 09/01. 
Ma, C., \& Valencia, M. F. (2018). Welfare Gains from Market Insurance: The Case of Mexican Oil Price Risk, International Monetary Fund Working Paper 18/35.

Marcet, A., \& Scott, A. (2009). Debt and deficit fluctuations and the structure of bond markets. Journal of Economic Theory, 144(2), 473-501.

McHugh, M. J., Petrova, I., \& Baldacci, M. E. (2011). Measuring fiscal vulnerability and fiscal stress: a proposed set of indicators. International Monetary Fund Working Paper No. 11-94.

Mendoza, E. G., \& Oviedo, P. M. (2006). Fiscal policy and macroeconomic uncertainty in developing countries: The tale of the tormented insurer. National Bureau of Economic Research Working Paper No. w12586

Noy, I., \& Nualsri, A. (2011). Fiscal storms: public spending and revenues in the aftermath of natural disasters. Environment and Development Economics, 16(1), 113-128.

Pedroni, P. (2013). Structural Panel VARs. Econometrics, 1(2), 180-206.

Plagborg-Møller, M., \& Wolf, C. K. (2017). Instrumental Variable Identification of Dynamic Variance Decompositions, manuscript.

Quinn, D. P., \& Toyoda, A. M. (2008). Does capital account liberalization lead to growth? The Review of Financial Studies, 21(3), 1403-1449.

Raddatz, C. (2008). External Shocks and Macroeconomic Volatility in Latin America. World Bank Policy Research Working Paper 4345.

Ricci, M. L. A., Chamon, M. M., \& Zhang, M. Y. S. (2011). Country Insurance Using Financial Instruments. International Monetary Fund Working Paper No. 11-169

Sahay, M. R., Arora, M. V. B., Arvanitis, M. A. V., Faruqee, M. H., N'Diaye, M. P., \& Griffoli, M. T. M. (2014). Emerging market volatility: Lessons from the taper tantrum. International Monetary Fund Working Paper No. 14-19.

Sandleris, G., H. Saprizza, and G. Taddei (2011). Indexed Sovereign Debt: An Applied Framework. The Colegio Alberto Notebooks Working Paper 104.

Shambaugh, J. C. (2004). The effect of fixed exchange rates on monetary policy. The Quarterly Journal of Economics, 119(1), 301-352.

Stock, J. H., \& Watson, M. W. (2018). Identification and Estimation of Dynamic Causal Effects in Macroeconomics Using External Instruments. The Economic Journal, 128(610), 917-948.

Tujula, M., \& Wolswijk, G. (2004). What determines fiscal balances? An empirical investigation in determinants of changes in OECD budget balances, ECB Working paper series N. 422. 
AnneX I. Data Statistics

\begin{tabular}{|c|c|c|c|c|c|c|}
\hline \multicolumn{7}{|c|}{ Summary statistics: All countries } \\
\hline & Mean & Median & $\begin{array}{c}25^{\text {th }} \\
\text { percentile }\end{array}$ & $\begin{array}{c}75^{\text {th }} \\
\text { percentile }\end{array}$ & Std. dev. & Obs. \\
\hline Overall fiscal balance, $\%$ of GDP & -3.0 & -2.6 & -5.1 & 0.0 & 13.8 & 6840 \\
\hline Overall government revenue, $\%$ of GDP & 28.7 & 25.8 & 18.5 & 36.9 & 14.7 & 6856 \\
\hline Overall government expenditure, $\%$ of GDP & 31.7 & 29.0 & 20.8 & 39.7 & 18.8 & 6851 \\
\hline Public debt, $\%$ of GDP & 56.9 & 44.5 & 26.4 & 70.2 & 54.5 & 6287 \\
\hline Change in debt to GDP ratio & -0.0 & 0.3 & -2.8 & 3.7 & 26.7 & 6051 \\
\hline Annual real GDP growth, percent & 3.8 & 3.8 & 1.5 & 6.3 & 5.9 & 7817 \\
\hline Annual inflation, percent & 10.7 & 5.7 & 2.3 & 11.6 & 18.5 & 7694 \\
\hline Commodity export price change, percent & 0.7 & -0.1 & -8.7 & 10.0 & 16.0 & 6392 \\
\hline Commodity import price change, percent & 0.5 & 0.2 & -7.4 & 10.3 & 15.1 & 6392 \\
\hline Change in unemployment rate & -0.1 & -0.1 & -0.6 & 0.4 & 1.4 & 3515 \\
\hline Transition year dummy, from PolityIV & 0.0 & 0.0 & 0.0 & 0.0 & 0.2 & 9302 \\
\hline Election year dummy & 0.3 & 0.0 & 0.0 & 1.0 & 0.4 & 4168 \\
\hline Democracy index, from PolityIV 1/ & $\ldots$ & 4.0 & 0.0 & 9.0 & 17.0 & 6802 \\
\hline Log population, deviation from quad. Trend & -0.0 & -0.0 & -0.8 & 0.7 & 3.1 & 7892 \\
\hline Oil trade balance, $\%$ of GDP & 1.0 & -2.1 & -4.4 & -0.0 & 12.9 & 6071 \\
\hline Average of imports and exports, $\%$ of GDP & 39.0 & 34.2 & 22.7 & 49.4 & 25.1 & 6808 \\
\hline Absolute value of NFA to GDP & 69.3 & 39.6 & 17.9 & 77.1 & 128.3 & 7100 \\
\hline
\end{tabular}




\begin{tabular}{|c|c|c|c|c|c|c|}
\hline \multicolumn{7}{|c|}{ Summary Statistics: All Countries } \\
\hline & Mean & Median & $\begin{array}{c}25^{\text {th }} \\
\text { percentile }\end{array}$ & $\begin{array}{c}75^{\text {th }} \\
\text { percentile }\end{array}$ & Std. dev. & Obs. \\
\hline Overall fiscal balance, $\%$ of GDP & -1.7 & -2.1 & -4.3 & 0.7 & 4.9 & 1479 \\
\hline Overall government revenue, $\%$ of GDP & 37.5 & 38.1 & 31.1 & 44.8 & 10.5 & 1479 \\
\hline Overall government expenditure, $\%$ of GDP & 39.3 & 40.7 & 33.4 & 47.6 & 11.6 & 1489 \\
\hline Public debt, $\%$ of GDP, HPDD & 53.1 & 46.6 & 28.1 & 68.7 & 36.2 & 1460 \\
\hline Change in debt to GDP ratio & 1.2 & 0.6 & -1.4 & 3.4 & 5.3 & 1332 \\
\hline Annual real GDP growth, percent & 3.3 & 3.0 & 1.5 & 4.9 & 3.8 & 1603 \\
\hline Annual inflation, percent & 5.5 & 3.0 & 1.6 & 6.4 & 9.2 & 1598 \\
\hline Commodity export price change & 0.5 & 0.3 & -6.8 & 8.5 & 13.2 & 1293 \\
\hline Commodity import price change & 0.5 & 0.6 & -6.4 & 9.6 & 15.1 & 1293 \\
\hline Change in unemployment rate, WDI & -0.0 & -0.1 & -0.7 & 0.5 & 1.4 & 962 \\
\hline Transition year dummy, from PolityIV & 0.0 & 0.0 & 0.0 & 0.0 & 0.1 & 1869 \\
\hline Election year dummy & 0.4 & 0.0 & 0.0 & 1.0 & 0.5 & 828 \\
\hline Democracy index, from PolityIV & 8.5 & 10.0 & 9.0 & 10.0 & 7.2 & 1398 \\
\hline Log population, deviation from quadratic trend & 0.0 & 0.0 & -0.7 & 0.7 & 1.5 & 1745 \\
\hline Oil trade balance, $\%$ of GDP & -1.9 & -1.8 & -3.3 & -0.9 & 4.1 & 1383 \\
\hline Average of imports and exports, $\%$ of GDP & 47.6 & 35.2 & 27.0 & 53.5 & 37.5 & 1365 \\
\hline Absolute value of NFA to GDP & & & & & & 1499 \\
\hline
\end{tabular}




\begin{tabular}{|c|c|c|c|c|c|c|}
\hline \multicolumn{7}{|c|}{ Summary Statistics: Emerging and Developing Countries Only } \\
\hline & Mean & Median & $25^{\text {th }}$ percentile & $\begin{array}{c}75^{\text {th }} \\
\text { percentile }\end{array}$ & Std. dev. & Obs. \\
\hline Overall fiscal balance, $\%$ of GDP & -3.3 & -2.7 & -5.4 & -0.2 & 15.4 & 5325 \\
\hline Overall government revenue, $\%$ of GDP & 26.1 & 23.3 & 17.0 & 31.7 & 14.3 & 5341 \\
\hline Overall government expenditure, $\%$ of GDP & 29.4 & 26.3 & 19.8 & 34.6 & 19.6 & 5326 \\
\hline Public debt, $\%$ of GDP, HPDD & 58.3 & 44.1 & 26.1 & 71.8 & 58.7 & 4889 \\
\hline Change in debt to GDP ratio & -0.4 & 0.2 & -3.4 & 3.9 & 30.2 & 4704 \\
\hline Annual real GDP growth, percent & 3.9 & 4.1 & 1.5 & 6.5 & 6.3 & 6145 \\
\hline Annual inflation, percent & 12.2 & 6.7 & 2.9 & 13.0 & 20.0 & 6062 \\
\hline Commodity export price change, percent & 0.7 & -0.3 & -9.3 & 10.4 & 16.6 & 5099 \\
\hline Commodity import price change, percent & 0.5 & 0.1 & -7.7 & 10.4 & 15.1 & 5099 \\
\hline Change in unemployment rate & -0.1 & -0.1 & -0.7 & 0.4 & 1.6 & 1990 \\
\hline Transition year dummy, from PolityIV & 0.0 & 0.0 & 0.0 & 0.0 & 0.2 & 7289 \\
\hline Election year dummy & 0.3 & 0.0 & 0.0 & 1.0 & 0.4 & 3340 \\
\hline Democracy index, from PolityIV 1/ & $\ldots$ & 1.0 & 0.0 & 7.0 & 18.2 & 5404 \\
\hline Log population, deviation from quadratic trend & -0.0 & -0.0 & -0.8 & 0.8 & 3.1 & 6214 \\
\hline Oil trade balance, $\%$ of GDP & 1.9 & -2.2 & -4.8 & 0.2 & 14.4 & 4688 \\
\hline Average of imports and exports, $\%$ of GDP & 36.7 & 33.7 & 21.9 & 48.4 & 20.2 & 5412 \\
\hline Absolute value of NFA to GDP & 76.5 & 43.4 & 21.5 & 84.4 & 140.5 & 5601 \\
\hline
\end{tabular}




\begin{tabular}{|c|c|c|c|c|c|c|}
\hline \multicolumn{7}{|c|}{ Summary Statistics for LAC Countries Only } \\
\hline & Mean & Median & $\begin{array}{c}25^{\text {th }} \\
\text { percentile }\end{array}$ & $\begin{array}{c}75^{\text {th }} \\
\text { percentile }\end{array}$ & Std. dev. & Obs. \\
\hline Overall fiscal balance, $\%$ of GDP & -3.0 & -2.7 & -4.6 & -0.5 & 4.9 & 1266 \\
\hline Overall government revenue, $\%$ of GDP & 22.3 & 22.9 & 17.5 & 27.1 & 7.7 & 1273 \\
\hline Overall government expenditure, $\%$ of GDP & 25.3 & 24.9 & 19.5 & 30.2 & 9.0 & 1266 \\
\hline Public debt, $\%$ of GDP, HPDD & 60.5 & 42.7 & 27.3 & 65.8 & 74.5 & 1329 \\
\hline Change in debt to GDP ratio & -0.8 & 0.4 & -3.1 & 4.0 & 51.7 & 1281 \\
\hline Annual real GDP growth, percent & 3.4 & 3.7 & 1.1 & 5.9 & 4.3 & 1475 \\
\hline Annual inflation, percent & 13.7 & 7.1 & 3.3 & 15.8 & 20.1 & 1429 \\
\hline Commodity export price change, percent & 0.3 & -0.4 & -9.2 & 9.9 & 15.6 & 1159 \\
\hline Commodity import price change, percent & 0.8 & 0.6 & -7.3 & 11.4 & 15.7 & 1159 \\
\hline Change in unemployment rate & -0.1 & -0.1 & -0.9 & 0.6 & 1.5 & 731 \\
\hline Transition year dummy, from PolityIV & 0.0 & 0.0 & 0.0 & 0.0 & 0.1 & 1507 \\
\hline Election year dummy & 0.3 & 0.0 & 0.0 & 1.0 & 0.4 & 734 \\
\hline Democracy index, from PolityIV 1/ & $\ldots$ & 7.0 & 2.0 & 9.0 & 14.8 & 1048 \\
\hline Log population, deviation from quadratic trend & -0.0 & -0.1 & -0.6 & 0.5 & 1.5 & 1438 \\
\hline Oil trade balance, $\%$ of GDP & -1.3 & -2.1 & -5.1 & 0.3 & 7.8 & 1056 \\
\hline Average of imports and exports, $\%$ of GDP & 34.6 & 31.4 & 21.1 & 46.4 & 17.8 & 1122 \\
\hline Absolute value of NFA to GDP & 59.1 & 39.6 & 19.4 & 80.5 & 62.3 & 1349 \\
\hline
\end{tabular}




\section{AnNeX II. Data Sources}

\section{Fiscal variables}

Fiscal variables are the target of our explanatory work. Yearly fiscal data is primarily from the IMF World Economic Outlook, complemented with the IMF Government Finance Statistics database for pre-1995 data. We focus on the overall government balance to GDP ratio, government revenues and expenditure (relative to GDP). We also use as outcome variables the change (when using LPM) or level (when using regular panels) of gross government debt to GDP ratio, extracted from the Historical Public Debt Database of Abbas et al. (2011) which allows a slightly more systematic coverage than the WEO data on general government debt ${ }^{1}$. International reserves (excluding gold) to GDP ratios are computed from the updated External Wealth of Nations database (Lane and Milesi-Ferretti, 2007).

\section{Trade and external variables}

Terms-of-trade (the ratio of export unit values to import unit values) for goods and services, or for goods only, as well as trade openness (defined as the average of exports and imports to GDP) are from the World Economic Outlook database. Foreign assets and liabilities (employed to assess net external debtors and creditors) are from the aforementioned External Wealth of Nations database. Data on exchange rate pegs are taken from the classification in Shambaugh (first introduced in Shambaugh, 2004), using the central binary dummy for pegged currency as a measure of the existence of a peg. For export and import commodity prices shocks, we use the database constructed by Gruss (2014) on trade-weighted commodity price indices, computed separately for exports and imports for a wide bundle of major commodity prices, and averaged at annual frequency, where trade weights are time-varying.

Data on global financial variables is from the World Economic Outlook for long-term US 10-year interest rates, the St-Louis Federal Reserve FRED database for the US effective fed funds rate, and the Chicago Board of Exchanges for the VIX volatility index, all averaged at yearly frequency. Nominal exchange rate data are obtained from the World Economic Outlook.

\section{Other domestic variables}

We use the Polity IV database from the World Bank as a measure of the democratic nature of the political regime, and to identify transition periods across any political regime (occurring in around $3 \%$ of country-years observations in our dataset). The dummy for election years is based on the database of election occurrence at the national level for all countries in our sample ${ }^{2}$.

\footnotetext{
${ }^{1}$ The correlation between these two measures of gross government debt to GDP is 0.95 in the subsample where both are available. None of our results are substantially affected when using the World Economic Outlook measure of debt to GDP ratio.

${ }^{2}$ We thank Karim Youssef for generously providing his election year database, based on http://www.electionguide.org/elections/past/.
} 
Natural disasters occurrence and damages are computed using the EM-DAT database developed by the CRED (Em-Dat, 2010). Assuming completeness of the reporting, we code the occurrence of a natural disaster as a dummy variable equal to one if a disaster is reported for a given country, and zero otherwise ${ }^{3}$. For robustness, we also experimented with alternative measures, such as the total amount of damages from disasters in a given country-year observation.

For military expenditure, we use data from the Stockholm International Peace Research Institute database, available after 1988 for a subset of countries in our sample.

Domestic systemic banking crises are taken from an updated version of the "Systemic banking crises database" put together by Laeven and Valencia (2008), using only banking crisis start year as a dummy variable for the occurrence of a crisis.

Population data are taken from the World Bank's World Development Indicators.

Domestic credit to the private sector to GDP, stock market capitalization to GDP, and yearly stock market volatility are from the World Bank's Global Financial Development database and the FinStats database.

\footnotetext{
${ }^{3}$ We use only non-human-made disasters, in the following categories: animal accident, drought, earthquake, epidemic, extreme temperature, flood, impact, insect infestation, landslide, mass movement, storm, volcanic activity, wildfire.
} 


\section{ANNEX III. LAC COUNTRIES}

This annex offers results for LAC countries for some of our key shocks or particular interest for this region.

\section{Analysis for LAC Countries of the Trade Shocks via LP Method}

Within the context of Emerging markets, it is interesting to zoom in for terms of trade shock on Latin American countries, as they are quite dependent on commodity exports. The region experiences a somewhat smaller increase in GDP and revenue ratios, but not the subsequent increase in expenditure ratio. Hence, the fiscal balance and gross debt improvement is more persistent in LAC.

\section{Responses to 1 s.d. in goods terms of trade LAC vs. Non-LAC Emerging}
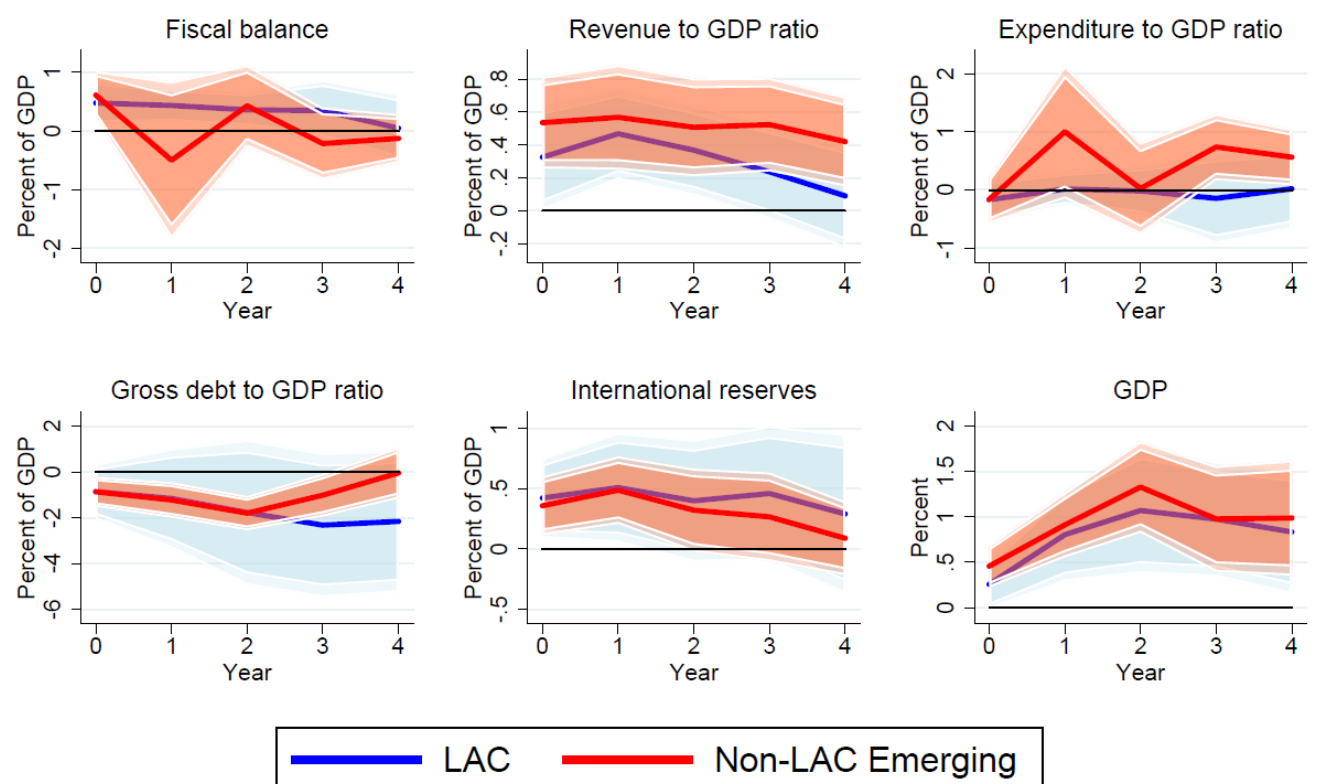

LP method

Countries in the LAC region appear particularly exposed to commodity price increases for imports, but not significantly different from other emerging commodity exporters as regards export prices (each analysis is confined to the group of the EMDC importers and exporters, respectively). The fiscal balance reacts strongly and positively (negatively) to export (import) commodity price changes, and so does the public debt to GDP ratio. This high degree of exposure can be quantified as follows:

- A one standard deviation increase in trade-weighted imported commodity prices (using only within country variation among Latin American countries) decreases the fiscal balance for LAC importers more than for other EMDC importers for the first three years: the effect reaches about $0.7 \%$ of GDP after a year for LAC importers and remains at such level, while other EMDC reach that level after 4 years. LAC countries also 
experience a substantial drop in GDP close to one percentage point, unlike in other emerging commodity importers.

- A one standard deviation increase in trade-weighted export commodity prices increases the fiscal balance of LAC exporters by about $1 / 2$ a percentage point of GDP after a year, and raises GDP by a similar amount after 2-3 years; the impact is similar to other commodity exporting economies.

Responses to 1 s.d. increase in comm. import prices LAC vs. Non-LAC Emerging
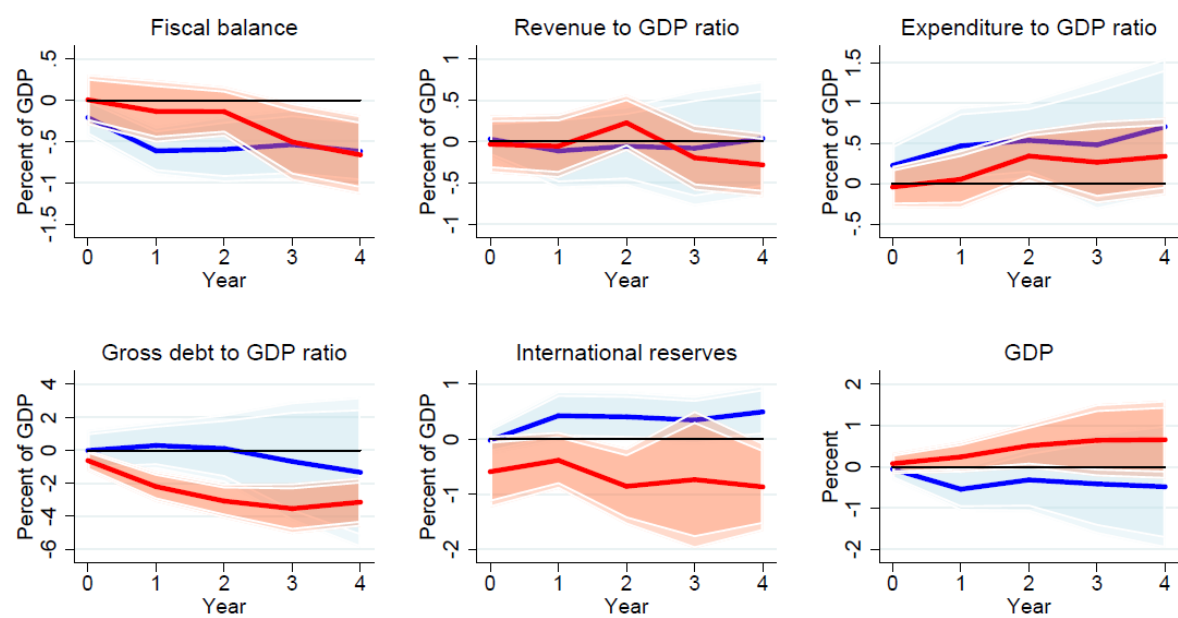

LAC

Non-LAC Emerging

LP method

Responses to 1 s.d. increase in comm. export prices LAC vs. Non-LAC Emerging
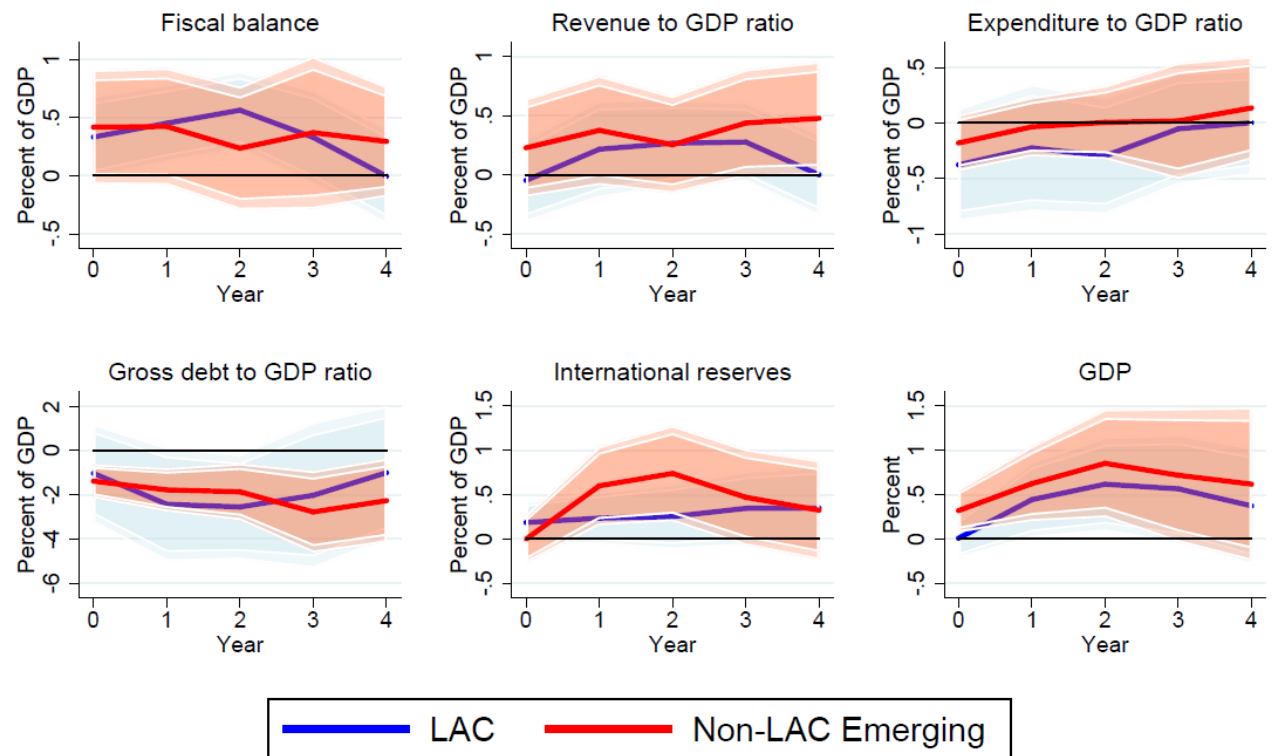

LP method 
Oil trade balance shocks also significantly affect the performance of Latin American countries, with a one percentage point of GDP improvement in the oil trade balance associated with a 0.3 percentage point increase in the fiscal balance, and a long-term decrease in the debt to GDP ratio of around 2 percentage points.

\section{Analysis for LAC Countries of the Domestic Growth Shock via LP Method}

Focusing on LAC countries, we observe effects qualitatively similar from a one percentage point domestic growth increase on the fiscal balance, revenue, expenditure, and public debt ratios as the ones observed more broadly for emerging and developing economies. However, the effect is quantitatively somewhat smaller but more persistent for the fiscal balance ratio in LAC countries. During the first few years, the lower effect on the fiscal balance ratio in LAC countries appears to stem from a more muted response of both the positive reaction of the revenue to GDP ratios and of the negative reaction of the expenditure to GDP ratio; over the medium term, the effect on the fiscal balance ratio remains positive in LAC (unlike other EMDC), thanks to the absence of a pick-up in the expenditure ratio. Given the offsetting effects of a larger persistence of the GDP impact, but a slightly smaller fiscal balance effect, the impact on gross debt to GDP ratios is similar in LAC countries to other emerging and developing economies.

\section{Responses to 1 p.p. increase in domestic real GDP growth LAC vs Non-LAC Emerging}
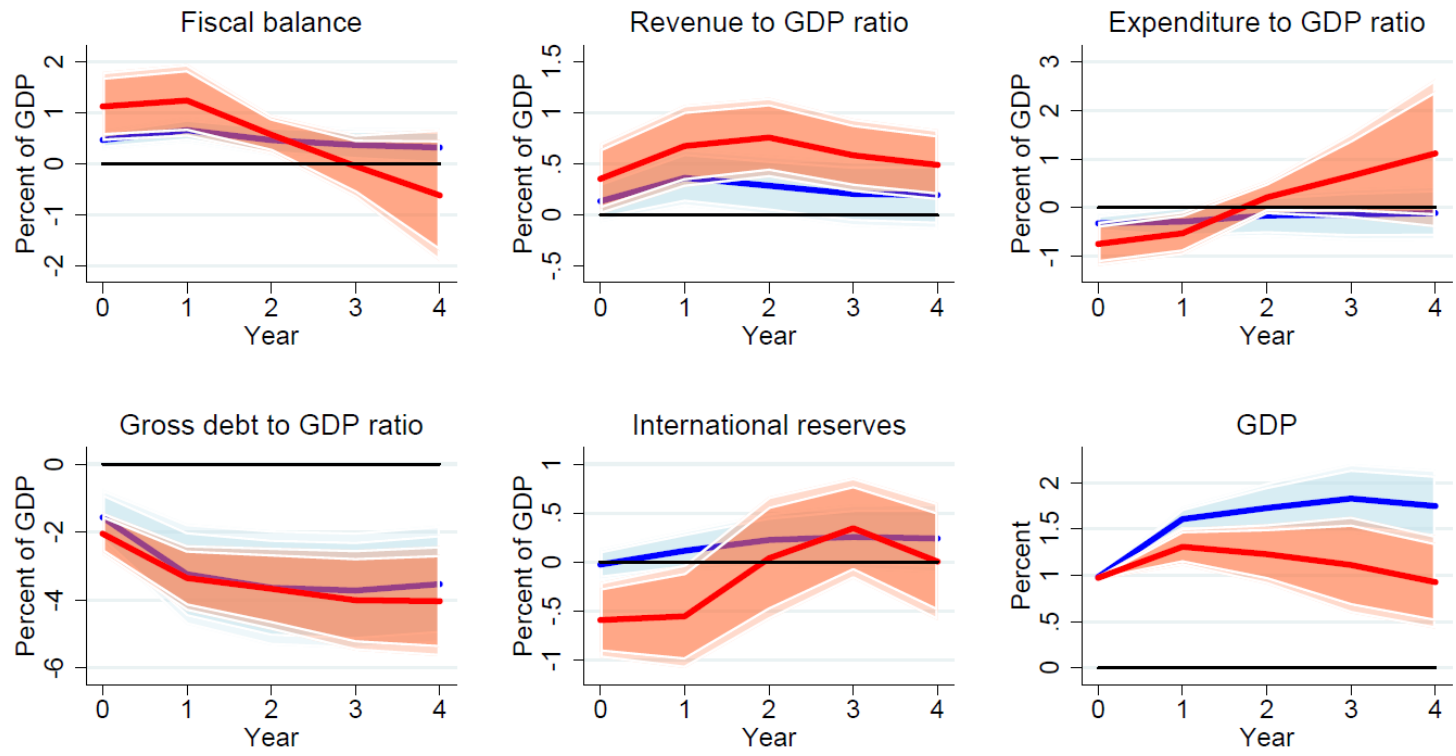

\section{LAC} Non-LAC Emerging

LP-IV method 
Annex IV. Panel Regressions for Different Country Groupings

\begin{tabular}{|c|c|c|c|c|c|c|c|c|}
\hline Advanced, main specification & $\begin{array}{c}\text { Fiscal } \\
\text { balance }\end{array}$ & Revenue & Expenditure & Gross debt & Net debt & $\begin{array}{l}\text { Reserves to } \\
\text { GDP }\end{array}$ & GDP growth & $\begin{array}{l}\text { NEER } \\
\text { change }\end{array}$ \\
\hline L.Overall fiscal balance, $\%$ of GDP & $\begin{array}{l}0.717^{* * * *} \\
{[0.0337]}\end{array}$ & & & & & & & \\
\hline Annual world real GDP growth, percent & $\begin{array}{l}0.697^{* * * *} \\
{[0.0760]}\end{array}$ & $\begin{array}{r}-0.00347 \\
{[0.0555]}\end{array}$ & $\begin{array}{c}-0.690^{* * * *} \\
{[0.0805]}\end{array}$ & $\begin{array}{c}-1.541^{* * * *} \\
{[0.160]}\end{array}$ & $\begin{array}{c}-1.232^{* * *} \\
{[0.404]}\end{array}$ & $\begin{array}{c}-0.310^{* *} \\
{[0.124]}\end{array}$ & $\begin{array}{c}1.046^{* * * *} \\
{[0.117]}\end{array}$ & $\begin{array}{l}-0.0677 \\
{[0.215]}\end{array}$ \\
\hline Standardized VIX & $\begin{array}{l}-0.239^{* * *} \\
{[0.0851]}\end{array}$ & $\begin{array}{c}-0.243^{* * * *} \\
{[0.0503]}\end{array}$ & $\begin{array}{c}0.0257 \\
{[0.0697]}\end{array}$ & $\begin{array}{c}0.0941 \\
{[0.239]}\end{array}$ & $\begin{array}{c}0.214 \\
{[0.391]}\end{array}$ & $\begin{array}{c}0.162 \\
{[0.162]}\end{array}$ & $\begin{array}{l}-0.261^{* * *} \\
{[0.0727]}\end{array}$ & $\begin{array}{c}-0.00556 \\
{[0.176]}\end{array}$ \\
\hline Commodity export price change, normalized & $\begin{array}{l}-0.125 \\
{[0.222]}\end{array}$ & $\begin{array}{l}0.0207 \\
{[0.118]}\end{array}$ & $\begin{array}{l}0.0971 \\
{[0.212]}\end{array}$ & $\begin{array}{c}0.398 \\
{[0.414]}\end{array}$ & $\begin{array}{l}-0.0713 \\
{[0.506]}\end{array}$ & $\begin{array}{c}0.159 \\
{[0.219]}\end{array}$ & $\begin{array}{l}0.227^{* *} \\
{[0.110]}\end{array}$ & $\begin{array}{c}0.537 \\
{[0.365]}\end{array}$ \\
\hline Commodity import price change, normalized & $\begin{array}{l}0.0280 \\
{[0.159]}\end{array}$ & $\begin{array}{l}0.0372 \\
{[0.120]}\end{array}$ & $\begin{array}{l}0.0321 \\
{[0.173]}\end{array}$ & $\begin{array}{c}0.289 \\
{[0.396]}\end{array}$ & $\begin{array}{c}0.780^{*} \\
{[0.397]}\end{array}$ & $\begin{array}{l}-0.307^{*} \\
{[0.160]}\end{array}$ & $\begin{array}{c}-0.246^{* *} \\
{[0.114]}\end{array}$ & $\begin{array}{l}0.0886 \\
{[0.345]}\end{array}$ \\
\hline $\begin{array}{l}\text { US government } 10 \text {-year constant maturity bond yield, } \\
\text { percent }\end{array}$ & $\begin{array}{l}0.00463 \\
{[0.0396]}\end{array}$ & $\begin{array}{c}-0.000565 \\
{[0.0315]}\end{array}$ & $\begin{array}{l}-0.0150 \\
{[0.0473]}\end{array}$ & $\begin{array}{c}-0.419^{* * * *} \\
{[0.110]}\end{array}$ & $\begin{array}{l}-0.441^{* *} \\
{[0.205]}\end{array}$ & $\begin{array}{l}-0.107 \\
{[0.0788]}\end{array}$ & $\begin{array}{l}0.300^{* * * *} \\
{[0.0609]}\end{array}$ & $\begin{array}{c}0.0363 \\
{[0.0809]}\end{array}$ \\
\hline Transition year dummy, from PolityIV & $\begin{array}{c}0.697^{* * * *} \\
{[0.173]}\end{array}$ & $\begin{array}{c}-0.448^{* *} \\
{[0.165]}\end{array}$ & $\begin{array}{l}-1.365^{* * * *} \\
{[0.240]}\end{array}$ & & & $\begin{array}{c}-1.721^{* * *} \\
{[0.516]}\end{array}$ & $\begin{array}{l}4.042^{* * * *} \\
{[0.236]}\end{array}$ & $\begin{array}{c}3.899^{* * * *} \\
{[0.702]}\end{array}$ \\
\hline Systemic banking crisis from Laeven-Valencia & $\begin{array}{l}-0.631 \\
{[0.689]}\end{array}$ & $\begin{array}{l}0.0217 \\
{[0.261]}\end{array}$ & $\begin{array}{c}0.792 \\
{[0.723]}\end{array}$ & $\begin{array}{l}2.921^{* *} \\
{[1.350]}\end{array}$ & $\begin{array}{l}-0.250 \\
{[1.527]}\end{array}$ & $\begin{array}{l}-0.976^{* *} \\
{[0.441]}\end{array}$ & $\begin{array}{l}-1.508^{* *} \\
{[0.659]}\end{array}$ & -0.0472 \\
\hline Log population, deviation from quadratic trend & $-0.211^{*}$ & $\begin{array}{l}0.0645^{*} \\
{[0.0366]}\end{array}$ & $0.260^{* * *}$ & $\begin{array}{l}0.838^{* *} \\
{[0.395]}\end{array}$ & $\begin{array}{l}0.951^{* *} \\
{[0.460]}\end{array}$ & $\begin{array}{c}0.142 \\
{[0.0847]}\end{array}$ & $-0.234^{* *}$ & $\begin{array}{l}-0.0281 \\
{[0.120]}\end{array}$ \\
\hline Damages from natural disasters, USD bn & $\begin{array}{l}-0.220 \\
{[0.182]}\end{array}$ & $\begin{array}{c}0.0272 \\
{[0.0774]}\end{array}$ & $\begin{array}{c}0.239^{* *} \\
{[0.0990]}\end{array}$ & $\begin{array}{l}0.784^{* * * *} \\
{[0.283]}\end{array}$ & $\begin{array}{l}1.223^{* * *} \\
{[0.336]}\end{array}$ & $\begin{array}{l}-0.0382 \\
{[0.172]}\end{array}$ & $\begin{array}{l}-0.222^{* * * *} \\
{[0.0545]}\end{array}$ & $\begin{array}{l}0.783^{* * *} \\
{[0.261]}\end{array}$ \\
\hline Damages from natural disasters $\mathrm{x} \log$ population & $\begin{array}{l}0.0113 \\
{[0.00956]}\end{array}$ & $\begin{array}{l}-0.00136 \\
{[0.00408]}\end{array}$ & $\begin{array}{l}-0.0123^{* *} \\
{[0.00523]}\end{array}$ & $\begin{array}{l}-0.0395^{* *} \\
{[0.0148]}\end{array}$ & $\begin{array}{l}-0.0634^{* * *} \\
{[0.0177]}\end{array}$ & $\begin{array}{l}0.00223 \\
{[0.00902]}\end{array}$ & $\begin{array}{l}0.0114^{* * * *} \\
{[0.00288]}\end{array}$ & $-0.0411^{* * *}$ \\
\hline L.Overall government revenue, $\%$ of GDP & & $\begin{array}{l}0.851^{* * * *} \\
{[0.0303]}\end{array}$ & & & & & & \\
\hline L.Overall government expenditure, $\%$ of GDP & & & $\begin{array}{l}0.790^{* * * *} \\
{[0.0291]}\end{array}$ & & & & & \\
\hline L.Public debt, $\%$ of GDP, HPDD & & & & $\begin{array}{l}0.973^{* * *} \\
{[0.0141]}\end{array}$ & & & & \\
\hline L.General govt net debt, $\%$ of GDP & & & & & $\begin{array}{l}0.975^{* * * *} \\
{[0.0171]}\end{array}$ & & & \\
\hline L.International reserves, $\%$ of USD GDP, EWN & & & & & & $\begin{array}{l}0.944^{* * * *} \\
{[0.0280]}\end{array}$ & & \\
\hline L.Annual real GDP growth, percent & & & & & & & $\begin{array}{l}0.336^{* * * *} \\
{[0.0398]}\end{array}$ & \\
\hline $\begin{array}{l}\text { L.Change in the nominal effective exchange rate, } \\
\text { percent }\end{array}$ & & & & & & & & $\begin{array}{l}0.319^{* * * *} \\
{[0.0405]}\end{array}$ \\
\hline Constant & $\begin{array}{l}-3.051^{* * * *} \\
{[0.377]}\end{array}$ & $\begin{array}{c}5.952^{* * * *} \\
{[1.232]}\end{array}$ & $\begin{array}{c}11.27^{* * * *} \\
{[1.251]}\end{array}$ & $\begin{array}{c}10.32^{* * * *} \\
{[1.148]}\end{array}$ & $\begin{array}{c}7.948^{* * * *} \\
{[1.852]}\end{array}$ & $\begin{array}{c}2.605^{* * * *} \\
{[0.565]}\end{array}$ & $\begin{array}{c}-3.385^{* * * *} \\
{[0.521]}\end{array}$ & $\begin{array}{c}0.126 \\
{[0.791]}\end{array}$ \\
\hline Adj. R-Square & 0.596 & 0.800 & 0.732 & 0.946 & 0.938 & 0.852 & 0.424 & 0.163 \\
\hline Observations & 1000 & 1000 & 1000 & 945 & 660 & 1000 & 994 & 1002 \\
\hline Countries & 35 & 35 & 35 & 34 & 31 & 35 & 35 & 35 \\
\hline
\end{tabular}

Standard errors in brackets

${ }^{*} p<0.10,{ }^{* *} p<0.05,{ }^{* * *} p<0.01,{ }^{* * * *} p<0.001$ 


\begin{tabular}{|c|c|c|c|c|c|c|c|c|}
\hline Emerging, main specification & $\begin{array}{c}\text { Fiscal } \\
\text { balance }\end{array}$ & Revenue & Expenditure & Gross debt & Net debt & $\begin{array}{c}\text { Reserves to } \\
\text { GDP }\end{array}$ & GDP growth & $\begin{array}{l}\text { NEER } \\
\text { change }\end{array}$ \\
\hline L.Overall fiscal balance, $\%$ of GDP & $\begin{array}{l}0.633^{* * *} \\
{[0.0884]}\end{array}$ & & & & & & & \\
\hline Annual world real GDP growth, percent & $\begin{array}{l}0.322^{* * * *} \\
{[0.115]}\end{array}$ & $\begin{array}{c}0.233^{*} \\
{[0.123]}\end{array}$ & $\begin{array}{l}-0.153^{* *} \\
{[0.0693]}\end{array}$ & $\begin{array}{l}-0.574^{*} \\
{[0.322]}\end{array}$ & $\begin{array}{l}-0.504 \\
{[0.499]}\end{array}$ & $\begin{array}{l}-0.303^{* *} \\
{[0.129]}\end{array}$ & $\begin{array}{l}0.563^{* * * *} \\
{[0.0949]}\end{array}$ & $\begin{array}{c}-0.444^{* *} \\
{[0.197]}\end{array}$ \\
\hline Standardized VIX & $\begin{array}{l}-0.255^{* * *} \\
{[0.0760]}\end{array}$ & $\begin{array}{l}-0.158^{* *} \\
{[0.0611]}\end{array}$ & $\begin{array}{c}0.0924 \\
{[0.0675]}\end{array}$ & $\begin{array}{c}0.895^{* * * *} \\
{[0.262]}\end{array}$ & $\begin{array}{l}0.0593 \\
{[0.435]}\end{array}$ & $\begin{array}{l}-0.207^{* *} \\
{[0.104]}\end{array}$ & $\begin{array}{c}-0.137 \\
{[0.0851]}\end{array}$ & $\begin{array}{l}-0.534^{* * *} \\
{[0.185]}\end{array}$ \\
\hline Commodity export price change, normalized & $\begin{array}{l}-0.0404 \\
{[0.145]}\end{array}$ & $\begin{array}{l}-0.187 \\
{[0.119]}\end{array}$ & $\begin{array}{l}-0.154 \\
{[0.135]}\end{array}$ & $\begin{array}{l}-1.001^{* *} \\
{[0.474]}\end{array}$ & $\begin{array}{c}0.605 \\
{[0.554]}\end{array}$ & $\begin{array}{l}-0.178 \\
{[0.167]}\end{array}$ & $\begin{array}{l}0.0489 \\
{[0.103]}\end{array}$ & $\begin{array}{c}0.379 \\
{[0.251]}\end{array}$ \\
\hline $\begin{array}{l}\text { Commodity export price change, normalized } \mathrm{x} \\
\text { exporter }\end{array}$ & $\begin{array}{c}1.430^{* * * *} \\
{[0.327]}\end{array}$ & $\begin{array}{c}0.901^{* * * *} \\
{[0.223]}\end{array}$ & $\begin{array}{l}-0.573^{* *} \\
{[0.250]}\end{array}$ & $\begin{array}{l}-1.339 \\
{[1.037]}\end{array}$ & $\begin{array}{l}-3.169^{* * *} \\
{[1.558]}\end{array}$ & $\begin{array}{c}0.264 \\
{[0.210]}\end{array}$ & $\begin{array}{c}0.281 \\
{[0.194]}\end{array}$ & $\begin{array}{c}0.284 \\
{[0.548]}\end{array}$ \\
\hline Commodity import price change, normalized & $\begin{array}{l}0.662^{* * *} \\
{[0.211]}\end{array}$ & $\begin{array}{c}0.220 \\
{[0.215]}\end{array}$ & $\begin{array}{l}-0.222 \\
{[0.165]}\end{array}$ & $\begin{array}{l}-1.368^{*} \\
{[0.703]}\end{array}$ & $\begin{array}{l}-0.230 \\
{[0.784]}\end{array}$ & $\begin{array}{l}-0.0812 \\
{[0.189]}\end{array}$ & $\begin{array}{c}0.201 \\
{[0.207]}\end{array}$ & $\begin{array}{l}0.0118 \\
{[0.355]}\end{array}$ \\
\hline $\begin{array}{l}\text { Commodity import price change, normalized } x \\
\text { importer }\end{array}$ & $\begin{array}{l}-0.632^{* *} \\
{[0.245]}\end{array}$ & $\begin{array}{l}-0.296 \\
{[0.231]}\end{array}$ & $\begin{array}{c}0.196 \\
{[0.209]}\end{array}$ & $\begin{array}{c}0.961 \\
{[0.851]}\end{array}$ & $\begin{array}{l}-0.619 \\
{[1.002]}\end{array}$ & $\begin{array}{l}-0.452 \\
{[0.305]}\end{array}$ & $\begin{array}{l}-0.0435 \\
{[0.217]}\end{array}$ & $\begin{array}{c}0.609 \\
{[0.414]}\end{array}$ \\
\hline $\begin{array}{l}\text { US government } 10 \text {-year constant maturity bond yield, } \\
\text { percent }\end{array}$ & $\begin{array}{c}0.0258 \\
{[0.0697]}\end{array}$ & $\begin{array}{l}-0.172^{* * *} \\
{[0.0575]}\end{array}$ & $\begin{array}{l}-0.179^{* * *} \\
{[0.0566]}\end{array}$ & $\begin{array}{l}0.426^{* *} \\
{[0.166]}\end{array}$ & $\begin{array}{l}-0.277 \\
{[0.324]}\end{array}$ & $\begin{array}{l}-0.122 \\
{[0.165]}\end{array}$ & $\begin{array}{c}-0.000639 \\
{[0.0537]}\end{array}$ & $\begin{array}{r}-0.445^{* * *} \\
{[0.158]}\end{array}$ \\
\hline Transition year dummy, from PolityIV & $\begin{array}{l}-4.544 \\
{[2.929]}\end{array}$ & $\begin{array}{c}-1.973^{* * *} \\
{[0.691]}\end{array}$ & $\begin{array}{c}2.229 \\
{[2.370]}\end{array}$ & $\begin{array}{c}11.89^{*} \\
{[6.311]}\end{array}$ & $\begin{array}{l}27.73^{* *} \\
{[13.73]}\end{array}$ & $\begin{array}{c}7.650 \\
{[6.679]}\end{array}$ & $\begin{array}{l}-5.414^{*} \\
{[3.241]}\end{array}$ & $\begin{array}{l}-2.404 \\
{[1.486]}\end{array}$ \\
\hline End of transition: into more democracy & $\begin{array}{c}2.455 \\
{[2.754]}\end{array}$ & $\begin{array}{c}1.191 \\
{[0.930]}\end{array}$ & $\begin{array}{l}-0.827 \\
{[2.151]}\end{array}$ & $\begin{array}{l}-9.257 \\
{[8.772]}\end{array}$ & $\begin{array}{l}-13.89^{*} \\
{[7.327]}\end{array}$ & $\begin{array}{l}-7.174 \\
{[6.014]}\end{array}$ & $\begin{array}{l}5.710^{*} \\
{[3.204]}\end{array}$ & $\begin{array}{c}2.137 \\
{[2.352]}\end{array}$ \\
\hline End of transition: into less democracy & $\begin{array}{l}0.0856 \\
{[4.296]}\end{array}$ & $\begin{array}{c}1.475 \\
{[0.955]}\end{array}$ & $\begin{array}{c}2.242 \\
{[4.359]}\end{array}$ & $\begin{array}{l}-4.500 \\
{[8.666]}\end{array}$ & $\begin{array}{l}-24.85^{*} \\
{[14.48]}\end{array}$ & $\begin{array}{l}-7.186 \\
{[5.790]}\end{array}$ & $\begin{array}{c}0.246 \\
{[3.988]}\end{array}$ & $\begin{array}{l}5.265^{* *} \\
{[2.030]}\end{array}$ \\
\hline Systemic banking crisis from Laeven-Valencia & $\begin{array}{l}-0.662 \\
{[0.475]}\end{array}$ & $\begin{array}{l}0.00511 \\
{[0.587]}\end{array}$ & $\begin{array}{c}0.685 \\
{[0.600]}\end{array}$ & $\begin{array}{l}7.102^{* *} \\
{[3.201]}\end{array}$ & $\begin{array}{c}14.25^{*} \\
{[8.215]}\end{array}$ & $\begin{array}{l}-1.051^{* *} \\
{[0.509]}\end{array}$ & $\begin{array}{c}-2.111^{* * * * *} \\
{[0.622]}\end{array}$ & $\begin{array}{l}-1.676 \\
{[1.796]}\end{array}$ \\
\hline Log population, deviation from quadratic trend & $\begin{array}{l}-0.142^{* * *} \\
{[0.0522]}\end{array}$ & $\begin{array}{l}-0.00833 \\
{[0.0186]}\end{array}$ & $\begin{array}{c}0.106^{* *} \\
{[0.0519]}\end{array}$ & $\begin{array}{c}0.0111 \\
{[0.0859]}\end{array}$ & $\begin{array}{l}-0.0679 \\
{[0.126]}\end{array}$ & $\begin{array}{l}-0.00132 \\
{[0.0197]}\end{array}$ & $\begin{array}{c}-0.0798^{* * *} \\
{[0.0258]}\end{array}$ & $\begin{array}{c}-0.00518 \\
{[0.0442]}\end{array}$ \\
\hline Damages from natural disasters, USD bn & $\begin{array}{c}-0.353 \\
{[0.311]}\end{array}$ & $\begin{array}{l}-0.122 \\
{[0.162]}\end{array}$ & $\begin{array}{c}0.248 \\
{[0.313]}\end{array}$ & $\begin{array}{c}1.435^{*} \\
{[0.763]}\end{array}$ & $\begin{array}{l}-2.621 \\
{[2.414]}\end{array}$ & $\begin{array}{c}0.190 \\
{[0.378]}\end{array}$ & $\begin{array}{l}-0.812^{*} \\
{[0.411]}\end{array}$ & $\begin{array}{l}-0.0567 \\
{[0.672]}\end{array}$ \\
\hline Damages from natural disasters $\mathrm{x} \log$ population & $\begin{array}{c}0.0172 \\
{[0.0147]}\end{array}$ & $\begin{array}{c}0.00787 \\
{[0.00793]}\end{array}$ & $\begin{array}{c}-0.0103 \\
{[0.0149]}\end{array}$ & $\begin{array}{l}-0.0684^{*} \\
{[0.0367]}\end{array}$ & $\begin{array}{c}0.176 \\
{[0.144]}\end{array}$ & $\begin{array}{l}-0.00992 \\
{[0.0180]}\end{array}$ & $\begin{array}{c}0.0386^{*} \\
{[0.0197]}\end{array}$ & $\begin{array}{l}0.00591 \\
{[0.0319]}\end{array}$ \\
\hline L. Overall government revenue, $\%$ of GDP & & $\begin{array}{l}0.687^{* * * *} \\
{[0.0655]}\end{array}$ & & & & & & \\
\hline L.Overall government expenditure, $\%$ of GDP & & & $\begin{array}{l}0.838^{* * * *} \\
{[0.0617]}\end{array}$ & & & & & \\
\hline L.Public debt, $\%$ of GDP, HPDD & & & & $\begin{array}{l}0.904^{* * * *} \\
{[0.0224]}\end{array}$ & & & & \\
\hline L.General govt net debt, $\%$ of GDP & & & & & $\begin{array}{l}0.935^{* * * *} \\
{[0.0120]}\end{array}$ & & & \\
\hline L.International reserves, $\%$ of USD GDP, EWN & & & & & & $\begin{array}{c}0.966^{* * * *} \\
{[0.115]}\end{array}$ & & \\
\hline L.Annual real GDP growth, percent & & & & & & & $\begin{array}{l}0.188^{* * * *} \\
{[0.0540]}\end{array}$ & \\
\hline $\begin{array}{l}\text { L.Change in the nominal effective exchange rate, } \\
\text { percent }\end{array}$ & & & & & & & & $\begin{array}{l}0.344^{* * * *} \\
{[0.0335]}\end{array}$ \\
\hline Constant & $\begin{array}{c}-2.144^{* * * *} \\
{[0.575]}\end{array}$ & $\begin{array}{c}8.135^{* * * *} \\
{[1.511]}\end{array}$ & $\begin{array}{c}6.082^{* * * *} \\
{[1.672]}\end{array}$ & $\begin{array}{l}4.788^{* *} \\
{[1.960]}\end{array}$ & $\begin{array}{c}3.464 \\
{[2.379]}\end{array}$ & $\begin{array}{c}2.794 \\
{[2.629]}\end{array}$ & $\begin{array}{l}1.350^{* * *} \\
{[0.441]}\end{array}$ & $\begin{array}{c}2.068^{*} \\
{[1.077]}\end{array}$ \\
\hline Adj. R-Square & 0.361 & 0.481 & 0.596 & 0.866 & 0.902 & 0.752 & 0.0988 & 0.176 \\
\hline Observations & 3791 & 3791 & 3792 & 3369 & 945 & 3837 & 3872 & 3912 \\
\hline Countries & 140 & 140 & 140 & 130 & 56 & 140 & 140 & 139 \\
\hline
\end{tabular}




\begin{tabular}{|c|c|c|c|c|c|c|c|c|}
\hline LAC, main specification & Fiscal balance & Revenue & Expenditure & Gross debt & Net debt & $\begin{array}{l}\text { Reserves to } \\
\text { GDP }\end{array}$ & GDP growth & NEER change \\
\hline L.Overall fiscal balance, $\%$ of GDP & $\begin{array}{l}0.687^{* * *} \\
{[0.0276]}\end{array}$ & & & & & & & \\
\hline Annual world real GDP growth, percent & $\begin{array}{l}0.217^{* * *} \\
{[0.0785]}\end{array}$ & $\begin{array}{c}0.202^{*} \\
{[0.109]}\end{array}$ & $\begin{array}{l}-0.0169 \\
{[0.118]}\end{array}$ & $\begin{array}{c}-0.172 \\
{[0.626]}\end{array}$ & $\begin{array}{l}-0.676 \\
{[0.424]}\end{array}$ & $\begin{array}{l}-0.316^{* *} \\
{[0.120]}\end{array}$ & $\begin{array}{c}0.613^{* * * *} \\
{[0.127]}\end{array}$ & $\begin{array}{l}-0.892^{* *} \\
{[0.431]}\end{array}$ \\
\hline Standardized VIX & $\begin{array}{l}-0.246^{* * *} \\
{[0.0908]}\end{array}$ & $\begin{array}{c}-0.102 \\
{[0.0875]}\end{array}$ & $\begin{array}{c}0.152 \\
{[0.0921]}\end{array}$ & $\begin{array}{l}1.979^{* * * *} \\
{[0.421]}\end{array}$ & $\begin{array}{c}0.726^{*} \\
{[0.365]}\end{array}$ & $\begin{array}{l}-0.0788 \\
{[0.0667]}\end{array}$ & $\begin{array}{c}-0.400^{* * *} \\
{[0.118]}\end{array}$ & $\begin{array}{l}-0.978^{* *} \\
{[0.378]}\end{array}$ \\
\hline Commodity export price change, normalized & $\begin{array}{l}0.238 \\
{[0.189]}\end{array}$ & $\begin{array}{l}-0.247 \\
{[0.185]}\end{array}$ & $\begin{array}{l}-0.484 \\
{[0.293]}\end{array}$ & $\begin{array}{l}-1.481 \\
{[1.056]}\end{array}$ & $\begin{array}{l}-0.130 \\
{[0.681]}\end{array}$ & $\begin{array}{c}0.0468 \\
{[0.0920]}\end{array}$ & $\begin{array}{c}-0.00642 \\
{[0.124]}\end{array}$ & $\begin{array}{l}1.021^{* *} \\
{[0.438]}\end{array}$ \\
\hline $\begin{array}{l}\text { Commodity export price change, normalized } \mathrm{x} \\
\text { exporter }\end{array}$ & $\begin{array}{l}0.197 \\
{[0.513]}\end{array}$ & $\begin{array}{l}0.969^{* * *} \\
{[0.348]}\end{array}$ & $\begin{array}{c}0.780 \\
{[0.471]}\end{array}$ & $\begin{array}{c}1.411 \\
{[1.254]}\end{array}$ & $\begin{array}{c}0.818 \\
{[0.869]}\end{array}$ & $\begin{array}{c}0.385 \\
{[0.369]}\end{array}$ & $\begin{array}{c}0.555^{*} \\
{[0.296]}\end{array}$ & $\begin{array}{c}0.550 \\
{[1.524]}\end{array}$ \\
\hline Commodity import price change, normalized & $\begin{array}{c}0.373 \\
{[0.277]}\end{array}$ & $\begin{array}{c}-0.262 \\
{[0.233]}\end{array}$ & $\begin{array}{l}-0.644^{*} \\
{[0.374]}\end{array}$ & $\begin{array}{l}-2.431^{* * *} \\
{[0.759]}\end{array}$ & $\begin{array}{l}-1.511^{* *} \\
{[0.586]}\end{array}$ & $\begin{array}{c}-0.00528 \\
{[0.252]}\end{array}$ & $\begin{array}{l}0.0217 \\
{[0.203]}\end{array}$ & $\begin{array}{c}-1.224 \\
{[1.027]}\end{array}$ \\
\hline $\begin{array}{l}\text { Commodity import price change, normalized } x \\
\text { importer }\end{array}$ & $\begin{array}{l}-0.424 \\
{[0.292]}\end{array}$ & $\begin{array}{c}0.304 \\
{[0.247]}\end{array}$ & $\begin{array}{c}0.735^{*} \\
{[0.384]}\end{array}$ & $\begin{array}{l}2.496^{* *} \\
{[0.962]}\end{array}$ & $\begin{array}{c}1.312 \\
{[0.835]}\end{array}$ & $\begin{array}{l}-0.0478 \\
{[0.250]}\end{array}$ & $\begin{array}{l}0.0871 \\
{[0.232]}\end{array}$ & $\begin{array}{c}1.281 \\
{[1.098]}\end{array}$ \\
\hline $\begin{array}{l}\text { US government } 10 \text {-year constant maturity bond yield, } \\
\text { percent }\end{array}$ & $\begin{array}{c}0.127^{* *} \\
{[0.0548]}\end{array}$ & $\begin{array}{l}-0.166^{* *} \\
{[0.0617]}\end{array}$ & $\begin{array}{l}-0.318^{* * * *} \\
{[0.0580]}\end{array}$ & $\begin{array}{l}-0.302 \\
{[0.214]}\end{array}$ & $\begin{array}{l}-0.812^{* *} \\
{[0.279]}\end{array}$ & $\begin{array}{l}-0.242^{* * * *} \\
{[0.0550]}\end{array}$ & $\begin{array}{l}0.210^{* * *} \\
{[0.0730]}\end{array}$ & $\begin{array}{l}0.0783 \\
{[0.430]}\end{array}$ \\
\hline Transition year dummy, from PolityIV & $\begin{array}{l}-0.240 \\
{[0.188]}\end{array}$ & $\begin{array}{l}0.731^{* * *} \\
{[0.206]}\end{array}$ & $\begin{array}{c}1.004^{* * * *} \\
{[0.206]}\end{array}$ & $\begin{array}{l}-0.0182 \\
{[0.888]}\end{array}$ & & $\begin{array}{l}1.378^{* * *} \\
{[0.388]}\end{array}$ & $\begin{array}{l}0.0822 \\
{[0.304]}\end{array}$ & $\begin{array}{c}5.927^{* * * *} \\
{[1.087]}\end{array}$ \\
\hline End of transition: into more democracy & $\begin{array}{c}0.280 \\
{[0.318]}\end{array}$ & $\begin{array}{l}0.0985 \\
{[0.649]}\end{array}$ & $\begin{array}{c}-0.328 \\
{[0.387]}\end{array}$ & $\begin{array}{c}1.946^{*} \\
{[1.083]}\end{array}$ & & $\begin{array}{c}-2.544^{* * * * *} \\
{[0.408]}\end{array}$ & $\begin{array}{c}-0.991 \\
{[1.305]}\end{array}$ & $\begin{array}{l}-5.882 \\
{[4.764]}\end{array}$ \\
\hline End of transition: into less democracy & $\begin{array}{c}0.513 \\
{[0.440]}\end{array}$ & $\begin{array}{c}3.053^{* * * *} \\
{[0.610]}\end{array}$ & $\begin{array}{l}2.380^{* * * *} \\
{[0.796]}\end{array}$ & $\begin{array}{c}25.50^{* * * * *} \\
{[2.606]}\end{array}$ & & $\begin{array}{c}-1.650^{* * * * *} \\
{[0.440]}\end{array}$ & $\begin{array}{c}0.00739 \\
{[0.455]}\end{array}$ & $\begin{array}{c}1.539 \\
{[2.205]}\end{array}$ \\
\hline Systemic banking crisis from Laeven-Valencia & $\begin{array}{l}-1.861^{* *} \\
{[0.849]}\end{array}$ & $\begin{array}{l}-1.391^{*} \\
{[0.799]}\end{array}$ & $\begin{array}{c}0.496 \\
{[1.182]}\end{array}$ & $\begin{array}{c}-0.727 \\
{[7.864]}\end{array}$ & $\begin{array}{l}31.54^{* * *} \\
{[8.602]}\end{array}$ & $\begin{array}{l}-1.119 \\
{[0.704]}\end{array}$ & $\begin{array}{l}-3.614^{* * *} \\
{[1.392]}\end{array}$ & $\begin{array}{l}-4.200 \\
{[3.611]}\end{array}$ \\
\hline Log population, deviation from quadratic trend & $\begin{array}{c}-0.0971 \\
{[0.0970]}\end{array}$ & $\begin{array}{l}0.000146 \\
{[0.0287]}\end{array}$ & $\begin{array}{c}0.0924 \\
{[0.0996]}\end{array}$ & $\begin{array}{c}0.448 \\
{[0.411]}\end{array}$ & $\begin{array}{c}0.296 \\
{[0.334]}\end{array}$ & $\begin{array}{c}-0.0904 \\
{[0.0942]}\end{array}$ & $\begin{array}{l}-0.0399 \\
{[0.126]}\end{array}$ & $\begin{array}{l}-0.418^{*} \\
{[0.239]}\end{array}$ \\
\hline Damages from natural disasters, USD bn & $\begin{array}{c}0.625 \\
{[0.733]}\end{array}$ & $\begin{array}{l}1.890^{* *} \\
{[0.781]}\end{array}$ & $\begin{array}{l}1.200 \\
{[0.964]}\end{array}$ & $\begin{array}{c}-0.994 \\
{[4.331]}\end{array}$ & $\begin{array}{c}1.210 \\
{[1.371]}\end{array}$ & $\begin{array}{c}2.613 \\
{[2.481]}\end{array}$ & $\begin{array}{l}-3.220 \\
{[2.287]}\end{array}$ & $\begin{array}{c}-11.14^{* * * * *} \\
{[2.445]}\end{array}$ \\
\hline Damages from natural disasters $\mathrm{x} \log$ population & $\begin{array}{c}-0.0349 \\
{[0.0430]}\end{array}$ & $\begin{array}{l}-0.112^{* *} \\
{[0.0452]}\end{array}$ & $\begin{array}{l}-0.0734 \\
{[0.0572]}\end{array}$ & $\begin{array}{c}0.0708 \\
{[0.254]}\end{array}$ & $\begin{array}{l}-0.0648 \\
{[0.0812]}\end{array}$ & $\begin{array}{c}-0.154 \\
{[0.143]}\end{array}$ & $\begin{array}{c}0.184 \\
{[0.133]}\end{array}$ & $\begin{array}{c}0.687^{* * * *} \\
{[0.144]}\end{array}$ \\
\hline L.Overall government revenue, $\%$ of GDP & & $\begin{array}{l}0.750^{* * * *} \\
{[0.0561]}\end{array}$ & & & & & & \\
\hline L.Overall government expenditure, $\%$ of GDP & & & $\begin{array}{l}0.710^{* * * *} \\
{[0.0450]}\end{array}$ & & & & & \\
\hline L.Public debt, \% of GDP, HPDD & & & & $\begin{array}{l}0.951^{* * * *} \\
{[0.0115]}\end{array}$ & & & & \\
\hline L.General govt net debt, $\%$ of GDP & & & & & $\begin{array}{l}0.964^{* * * *} \\
{[0.0254]}\end{array}$ & & & \\
\hline L.International reserves, $\%$ of USD GDP, EWN & & & & & & $\begin{array}{l}0.888^{* * * *} \\
{[0.0238]}\end{array}$ & & \\
\hline L.Annual real GDP growth, percent & & & & & & & $\begin{array}{l}0.249^{* * * *} \\
{[0.0454]}\end{array}$ & \\
\hline $\begin{array}{l}\text { L.Change in the nominal effective exchange rate, } \\
\text { percent }\end{array}$ & & & & & & & & $\begin{array}{l}0.413^{* * * *} \\
{[0.0637]}\end{array}$ \\
\hline Constant & $\begin{array}{c}-2.155^{* * * *} \\
{[0.457]}\end{array}$ & $\begin{array}{c}6.015^{* * * *} \\
{[1.392]}\end{array}$ & $\begin{array}{c}9.166^{* * * *} \\
{[1.049]}\end{array}$ & $\begin{array}{c}4.039 \\
{[3.150]}\end{array}$ & $\begin{array}{l}5.987^{* * *} \\
{[1.679]}\end{array}$ & $\begin{array}{c}4.072^{* * * *} \\
{[0.613]}\end{array}$ & $\begin{array}{c}-0.709 \\
{[0.689]}\end{array}$ & $\begin{array}{c}2.222 \\
{[3.184]}\end{array}$ \\
\hline Adj. R-Square & 0.540 & 0.634 & 0.629 & 0.932 & 0.870 & 0.839 & 0.168 & 0.234 \\
\hline Observations & 909 & 909 & 909 & 894 & 245 & 934 & 934 & 934 \\
\hline Countries & 32 & 32 & 32 & 32 & 14 & 32 & 32 & 32 \\
\hline
\end{tabular}


ANnex V. CoRrelation MATRiX OF SHOCKS

\begin{tabular}{|c|c|c|c|c|c|c|c|c|c|c|}
\hline $\begin{array}{c}\text { Correlation matrix of shocks } \\
\text { (all countries) }\end{array}$ & World growth & $\begin{array}{l}\text { Goods terms- } \\
\text { of-trade } \\
\text { change } \\
\text { (normalized) }\end{array}$ & $\begin{array}{l}\text { Commodity } \\
\text { import price } \\
\text { change } \\
\text { (normalized) }\end{array}$ & $\begin{array}{l}\text { Commodity } \\
\text { export price } \\
\text { change } \\
\text { (normalized) }\end{array}$ & $\begin{array}{c}\text { VIX } \\
\text { (normalized) }\end{array}$ & $\begin{array}{l}\text { US } 10 \text { year } \\
\text { yield } \\
\text { (normalized) }\end{array}$ & $\begin{array}{l}\text { Banking crisis } \\
\text { (dummy) }\end{array}$ & $\begin{array}{c}\text { Transition } \\
\text { (dummy) }\end{array}$ & $\begin{array}{c}\text { Population } \\
\text { (log deviation) }\end{array}$ & $\begin{array}{l}\text { Election } \\
\text { (dummy) }\end{array}$ \\
\hline World growth & 1.00 & 0.03 & 0.63 & 0.55 & -0.56 & 0.12 & -0.05 & 0.01 & -0.04 & 0.03 \\
\hline Goods terms-of-tr ade change (normalized) & 0.03 & 1.00 & 0.01 & 0.14 & 0.00 & 0.00 & -0.03 & 0.01 & -0.02 & 0.01 \\
\hline $\begin{array}{c}\text { Commodity import price change } \\
\text { (normalized) } \\
\text { Commodity export price change }\end{array}$ & 0.63 & 0.01 & 1.00 & 0.72 & -0.05 & 0.25 & 0.04 & 0.01 & -0.07 & 0.01 \\
\hline & 0.55 & 0.14 & 0.72 & 1.00 & -0.07 & 0.16 & 0.00 & -0.01 & -0.09 & 0.03 \\
\hline (normalized) & -0.56 & 0.00 & -0.05 & -0.07 & 1.00 & 0.04 & 0.09 & 0.00 & -0.03 & 0.04 \\
\hline US 10 year yield (normalized) & 0.12 & 0.00 & 0.25 & 0.16 & 0.04 & 1.00 & 0.07 & -0.01 & -0.12 & -0.17 \\
\hline Banking crisis (dummy) & -0.05 & -0.03 & 0.04 & 0.00 & 0.09 & 0.07 & 1.00 & -0.02 & 0.02 & -0.02 \\
\hline Transition (dummy) & 0.01 & 0.01 & 0.01 & -0.01 & 0.00 & -0.01 & -0.02 & 1.00 & -0.03 & -0.01 \\
\hline $\begin{array}{c}\text { Population } \\
\text { (log deviation) }\end{array}$ & -0.04 & -0.02 & -0.07 & -0.09 & -0.03 & -0.12 & 0.02 & -0.03 & 1.00 & 0.02 \\
\hline Election (dummy) & 0.03 & 0.01 & 0.01 & 0.03 & 0.04 & -0.17 & -0.02 & -0.01 & 0.02 & 1.00 \\
\hline
\end{tabular}


ANNEX VI. FisCAL COST OF SHOCKS: REVENUE, EXPENDITURE

\begin{tabular}{|c|c|c|c|c|c|c|c|c|c|c|}
\hline $\begin{array}{c}\text { Revemue } \\
\text { impact }\end{array}$ & $\begin{array}{c}\text { World growth } \\
\text { (normalized } \\
\beta \times \sigma(\text { var }))\end{array}$ & $\begin{array}{l}\text { Goods terms-of- } \\
\text { trade change } \\
(\text { normalized } \\
\beta \times \sigma(\text { var }))\end{array}$ & $\begin{array}{l}\text { Commodity import } \\
\text { price change } \\
(\text { normalized } \\
\beta \times \sigma(\text { var }))\end{array}$ & $\begin{array}{l}\text { Commodity export } \\
\text { price change } \\
(\text { normalized } \\
\beta \times \sigma(\text { var }))\end{array}$ & $\begin{array}{c}\text { VIX } \\
\text { (normalized } \\
\beta \times \sigma(\text { var }))\end{array}$ & $\begin{array}{c}\text { US } 10 \text { year } \\
\text { yield } \\
(\text { normalized } \\
\beta \times \sigma(\text { var }))\end{array}$ & $\begin{array}{l}\text { Banking crisis } \\
\text { (dummy, } \beta \text { ) }\end{array}$ & $\begin{array}{c}\text { Transition } \\
\text { (dummy, } \beta)\end{array}$ & $\begin{array}{c}\text { Population } \\
\text { (log deviation, } \\
\text { normalized } \\
\beta \times \sigma(\text { var }))\end{array}$ & $\begin{array}{c}\text { Election } \\
(\text { dummy, } \beta)\end{array}$ \\
\hline \multicolumn{11}{|c|}{ 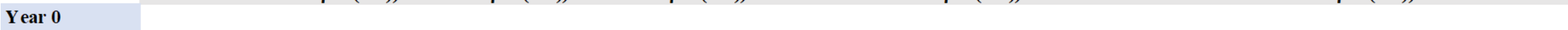 } \\
\hline All & 0.36 & 0.36 & -0.03 & 0.11 & -0.04 & -0.42 & -0.88 & -1.81 & 0.11 & -0.12 \\
\hline$E M$ & 0.46 & 0.48 & -0.01 & 0.14 & -0.01 & -0.63 & -1.03 & -1.80 & -0.02 & -0.15 \\
\hline$A E$ & 0.02 & -0.05 & -0.10 & 0.09 & -0.11 & -0.01 & -0.34 & & 0.36 & -0.01 \\
\hline$L A C$ & 0.24 & 0.32 & 0.03 & -0.05 & -0.10 & -0.52 & -1.94 & 0.53 & -1.51 & -0.06 \\
\hline \multicolumn{11}{|l|}{ Year 1} \\
\hline$A l l$ & 0.40 & 0.42 & -0.06 & 0.25 & -0.51 & 0.43 & -1.34 & -0.93 & -0.07 & 0.05 \\
\hline$E M$ & 0.51 & 0.54 & -0.03 & 0.31 & -0.56 & 0.13 & -1.36 & -0.92 & -0.15 & 0.11 \\
\hline$A E$ & 0.03 & 0.05 & -0.07 & 0.07 & -0.35 & 1.14 & -0.94 & & 0.42 & -0.09 \\
\hline$L A C$ & 0.35 & 0.46 & -0.12 & 0.22 & -0.44 & 0.49 & -2.03 & 2.47 & -1.97 & 0.22 \\
\hline \multicolumn{11}{|l|}{ Year 2} \\
\hline All & 0.28 & 0.36 & 0.14 & 0.18 & -0.58 & 1.16 & -0.67 & -0.96 & -1.01 & -0.06 \\
\hline$E M$ & 0.37 & 0.46 & 0.21 & 0.24 & -0.66 & 0.91 & -0.26 & -0.96 & -1.27 & -0.03 \\
\hline$A E$ & 0.01 & 0.07 & -0.05 & 0.06 & -0.38 & 1.62 & -1.15 & & 0.14 & -0.11 \\
\hline$L A C$ & 0.11 & 0.37 & -0.06 & 0.27 & -0.46 & 1.08 & -0.47 & 3.50 & -1.15 & 0.37 \\
\hline \multicolumn{11}{|l|}{ Year 3} \\
\hline All & 0.19 & 0.30 & -0.11 & 0.29 & -0.25 & 1.17 & -0.65 & -0.47 & -1.31 & -0.11 \\
\hline$E M$ & 0.29 & 0.43 & -0.09 & 0.35 & -0.29 & 0.73 & -0.27 & -0.46 & -1.90 & -0.11 \\
\hline$A E$ & -0.18 & -0.04 & 0.01 & 0.08 & -0.18 & 1.96 & -0.99 & & 0.60 & -0.11 \\
\hline$L A C$ & 0.07 & 0.24 & -0.08 & 0.28 & -0.32 & 1.42 & -0.04 & 3.19 & -0.26 & 0.21 \\
\hline
\end{tabular}




\begin{tabular}{|c|c|c|c|c|c|c|c|c|c|c|}
\hline $\begin{array}{c}\text { Expenditure } \\
\text { impact }\end{array}$ & $\begin{array}{c}\text { World growth } \\
\text { (normalized } \\
\beta \times \sigma(\text { var }))\end{array}$ & $\begin{array}{l}\text { Goods terms-of- } \\
\text { trade change } \\
\text { (normalized } \\
\beta \times \sigma(\text { var }))\end{array}$ & $\begin{array}{l}\text { Commodity import } \\
\text { price change } \\
(\text { normalized } \\
\beta \times \sigma(\text { var }))\end{array}$ & $\begin{array}{l}\text { Commodity export } \\
\text { price change } \\
\text { (normalized } \\
\beta \times \sigma(\text { var }))\end{array}$ & $\begin{array}{c}\text { VIX } \\
\text { (normalized } \\
\beta \times \sigma(\text { var }))\end{array}$ & $\begin{array}{l}\text { US } 10 \text { year } \\
\text { yield } \\
(\text { normalized } \\
\beta \times \sigma(\text { var }))\end{array}$ & $\begin{array}{c}\text { Banking crisis } \\
\text { (dummy, } \boldsymbol{\beta})\end{array}$ & $\begin{array}{c}\text { Transition } \\
\text { (dummy, } \beta \text { ) }\end{array}$ & $\begin{array}{c}\text { Population } \\
\text { (log deviation, } \\
\text { normalized } \\
\beta \times \sigma(\text { var }))\end{array}$ & $\begin{array}{c}\text { Election } \\
(\text { dummy, } \beta)\end{array}$ \\
\hline \multicolumn{11}{|c|}{ 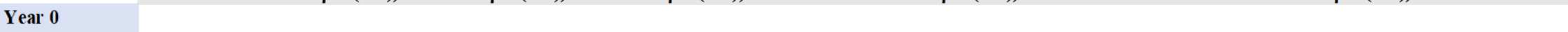 } \\
\hline All & -0.55 & -0.20 & 0.09 & -0.19 & 0.42 & -0.12 & 1.15 & 1.59 & 0.38 & 0.39 \\
\hline$E M$ & -0.45 & -0.19 & 0.03 & -0.23 & 0.46 & -0.10 & 0.70 & 1.56 & 0.52 & 0.52 \\
\hline$A E$ & -0.91 & -0.23 & 0.15 & 0.01 & 0.35 & -0.32 & 1.93 & & 0.35 & 0.10 \\
\hline$L A C$ & -0.40 & -0.17 & 0.23 & -0.38 & 0.21 & -0.58 & -0.07 & -0.34 & -7.65 & 0.14 \\
\hline \multicolumn{11}{|l|}{ Year 1} \\
\hline All & -0.68 & 0.47 & 0.24 & -0.08 & 0.95 & -0.98 & 1.70 & 4.01 & -0.46 & 0.24 \\
\hline$E M$ & -0.52 & 0.72 & 0.17 & -0.09 & 0.89 & -1.18 & 0.14 & 3.93 & -1.11 & 0.34 \\
\hline$A E$ & -1.15 & -0.28 & 0.45 & -0.09 & 1.21 & -0.37 & 4.95 & & 1.20 & 0.11 \\
\hline$L A C$ & -0.71 & 0.02 & 0.47 & -0.23 & 0.33 & 0.44 & -0.45 & 1.32 & -10.66 & -0.02 \\
\hline \multicolumn{11}{|l|}{ Year 2} \\
\hline All & -0.34 & -0.04 & 0.44 & -0.06 & 0.45 & -1.92 & 2.35 & 2.83 & -0.03 & 0.41 \\
\hline$E M$ & -0.26 & 0.01 & 0.41 & -0.05 & 0.27 & -2.36 & 0.75 & 2.68 & -0.74 & 0.65 \\
\hline$A E$ & -0.50 & -0.14 & 0.51 & -0.15 & 1.01 & -0.88 & 5.32 & & 1.50 & 0.03 \\
\hline$L A C$ & -0.53 & -0.02 & 0.54 & -0.30 & 0.14 & -0.19 & 0.33 & 3.15 & -12.97 & 0.25 \\
\hline \multicolumn{11}{|l|}{ Year 3} \\
\hline All & -0.18 & 0.33 & 0.37 & 0.03 & 0.12 & -1.39 & 1.43 & 3.01 & 0.22 & 0.11 \\
\hline$E M$ & -0.14 & 0.51 & 0.34 & 0.02 & 0.01 & -1.57 & 0.38 & 2.85 & -0.64 & 0.30 \\
\hline$A E$ & -0.35 & -0.13 & 0.57 & 0.27 & 035 & -1.23 & 2.83 & & 2.03 & 0.03 \\
\hline$L A C$ & -0.55 & -0.14 & 0.49 & -0.05 & -0.07 & -0.40 & 0.26 & 4.04 & -11.48 & 0.26 \\
\hline
\end{tabular}




\section{ANNEX VII. VARIANCE Decomposition ChaRTS}

This annex offers a variance decomposition exercise to quantify the relative importance of various sources of fluctuations of the fiscal deficit.

Inference and forecast error variance decomposition at various horizons under local projection methods are intricate matters (see Stock and Watson, 2018; and Plagborg-Moller and Wolf, 2017). We implement the approach defined in Gorodnichenko and Lee (2017) to compute the share of variance in the $h$-steps ahead forecast explained by a given shock at various horizons in local projection methods.

This approach relies first on computing forecast errors of outcome variables at each projection horizon, using the local projection method; then, in a second step, it involves comparing the $(t-1)$ forecast error variance with the variance of the best linear predictor of the time $t+h$ outcome, using the values of the variable of interest between the time of impact and the projection horizon. The ratio of the (sample) variance of the predicted value to the variance of the $(t-1)$ forecast error provides an estimate of the share of variance explained by the shock at each horizon.

Formally, using the suggestion from Gorodnichenko and Lee (2017), and starting back from our specification for exogenous shocks:

$$
y_{i t+h}-y_{i t-1}=\alpha_{i}+A^{h}(L) \Delta y_{i, t-1}+\beta_{h}(L) D_{i t}+B^{h}(L) X_{i t}+\varepsilon_{i t h}
$$

The share $s_{h}$ of the forecast error variance at horizon $h$ accounted for by variable $D_{i}$ can then be estimated quite directly from the local projection exercise as $\widehat{s_{h} P}$, where $f_{t+h \mid t-1}$ is the $h$ steps ahead forecast error at time $t-1$ :

$$
\begin{aligned}
& \widehat{s_{h}}=\frac{\operatorname{Var}\left(\beta_{0}(0) D_{i, t+h}+\beta_{1}(0) D_{i, t+h-1}+\cdots+\beta_{h}(0) D_{i, t}\right)}{\operatorname{Var}\left(f_{t+h \mid t-1}\right)} \\
& =\frac{\left(\sum_{i=0}^{h} \widehat{\beta}_{l}(0)^{2}\right){\widehat{\sigma_{D}}}^{2}}{\operatorname{Var}\left(\widehat{\varepsilon_{l t h}}+\beta_{h}(0) D_{i, t}\right)} \\
& =\frac{\left(\sum_{i=0}^{h} \widehat{\beta}_{l}(0)^{2}\right){\widehat{\sigma_{D}}}^{2}}{\left(\sum_{i=0}^{h}{\widehat{\beta_{l}}}(0)^{2}\right){\widehat{\sigma_{D}}}^{2}+\operatorname{Var}\left(\widehat{\varepsilon_{l t h}}-\widehat{\beta_{h-1}}(0) D_{i, t+1}-\cdots-\widehat{\beta_{0}(0)} D_{i, t+h}\right)}
\end{aligned}
$$

The first step consists in computing the standard deviation for each of our main shocks, each country type, and each horizon, and establishing "country profiles" of vulnerability to a given subset of shocks over time. We focus on the following series of shocks: world growth, world growth interacted with openness, change in export prices, change in import prices, election year, political transitions, change in the VIX, change in US 10-year yields. Here, the variation in the "treatment variable" ${\widehat{\sigma_{D}}}^{2}$ is taken to be only the within-country variation $\left(\operatorname{Var}\left(D_{i, t}-\bar{D}_{l}\right)\right)$, and similarly for the variation in forecast-error, where the residuals do not include country fixed effects. 
The graphs below show the results from this "forecast error variance reduction" exercise for a few of the key exogenous driving shocks, reporting in percentages the share of variance reduction in fiscal balance forecast errors that would be obtained at various horizons from knowing the full sequence of shocks up to that horizons (see Plagborg-Moller and Wolf, 2017).

Most of the shocks analyzed tend to account for a smaller share of variation of fiscal balances in advanced economies than in emerging markets and developing countries. Also, the role of most shocks in explaining the variance of fiscal deficits tends to grow over time; the notable exception is the shock to global growth, whose role tends to decline after one year. It is remarkable that the most important shocks are the VIX (especially for countries with high financial openness) and commodity prices, in addition to global growth.

We can also attempt a very preliminary decomposition of the relative contribution of expenditure and revenue shocks to the fiscal balance ratio, and find that the expenditure ratio is a much more important predictor of short-term fluctuations. Expenditure also appears to play a relatively larger role in explaining forecast errors in emerging economies and Latin American countries (relative to revenue shocks) than in advanced economies.
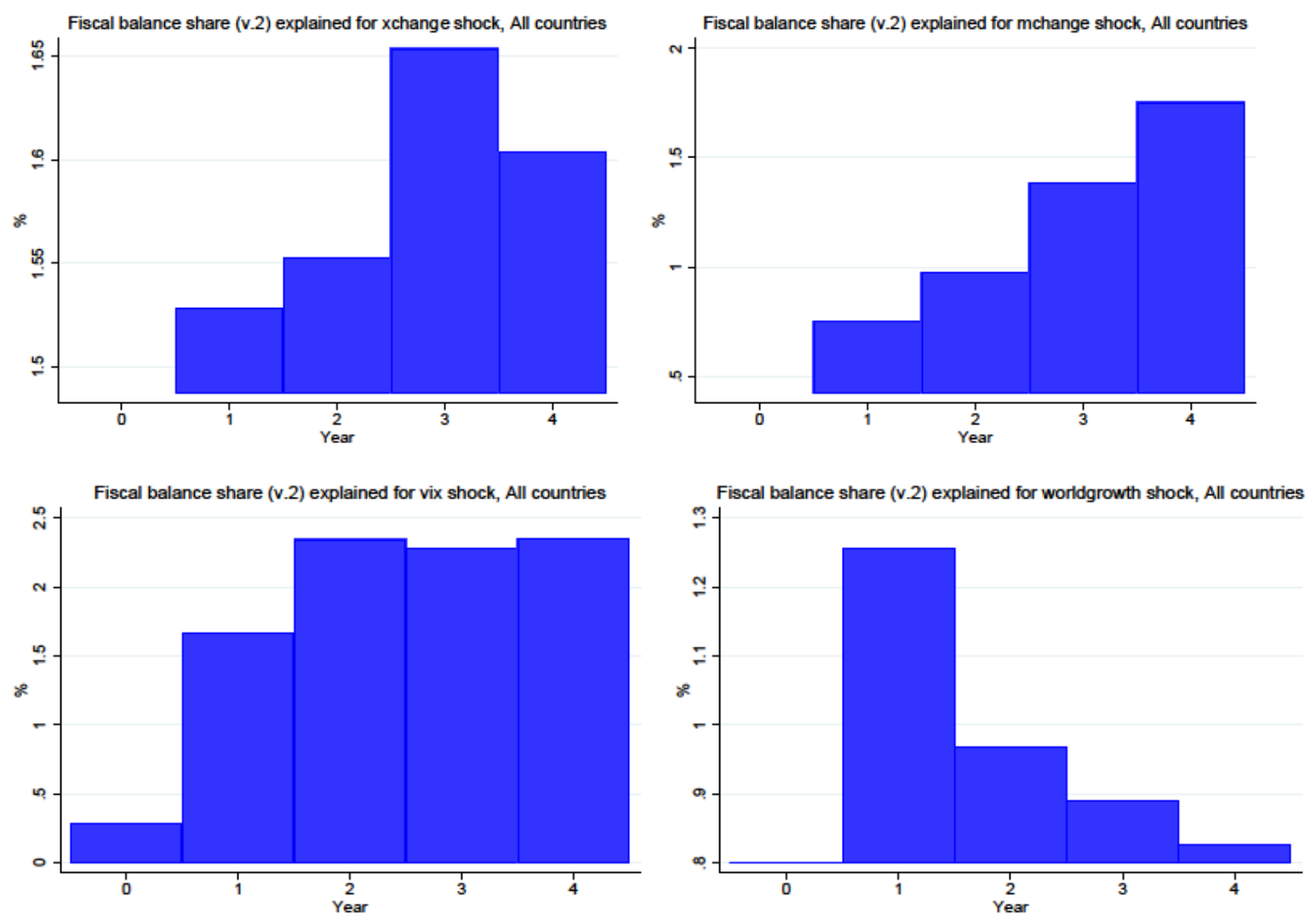

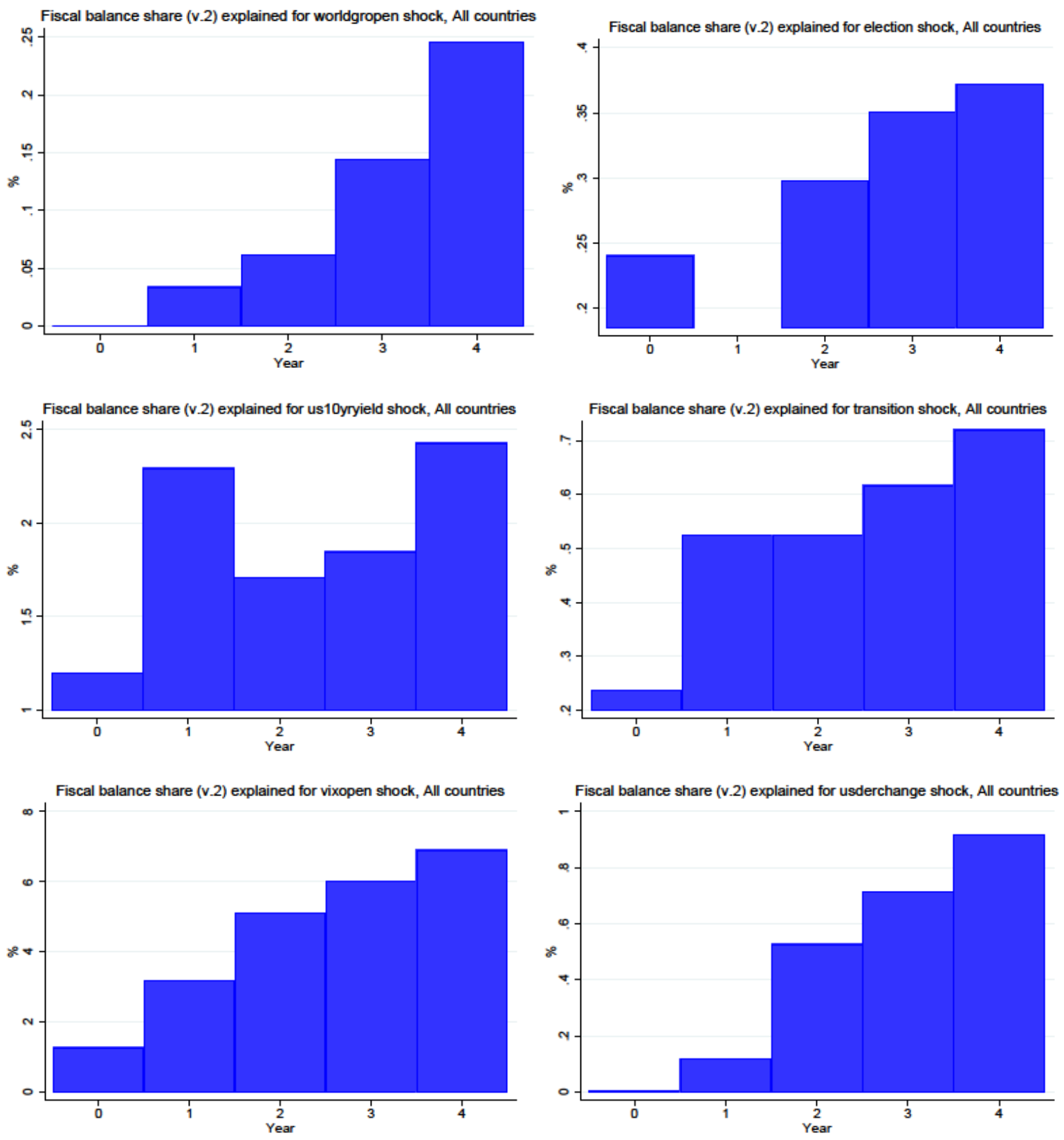

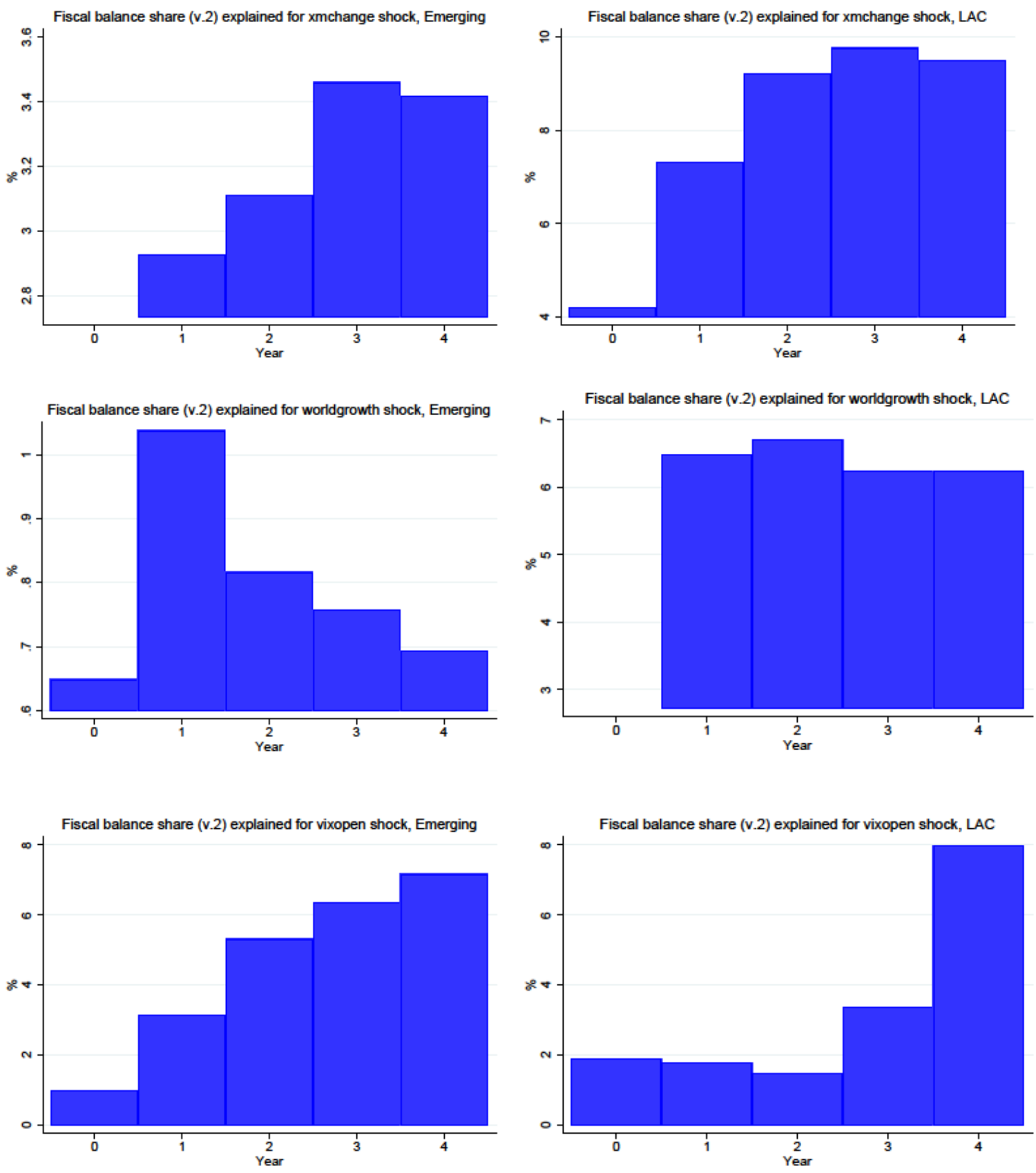

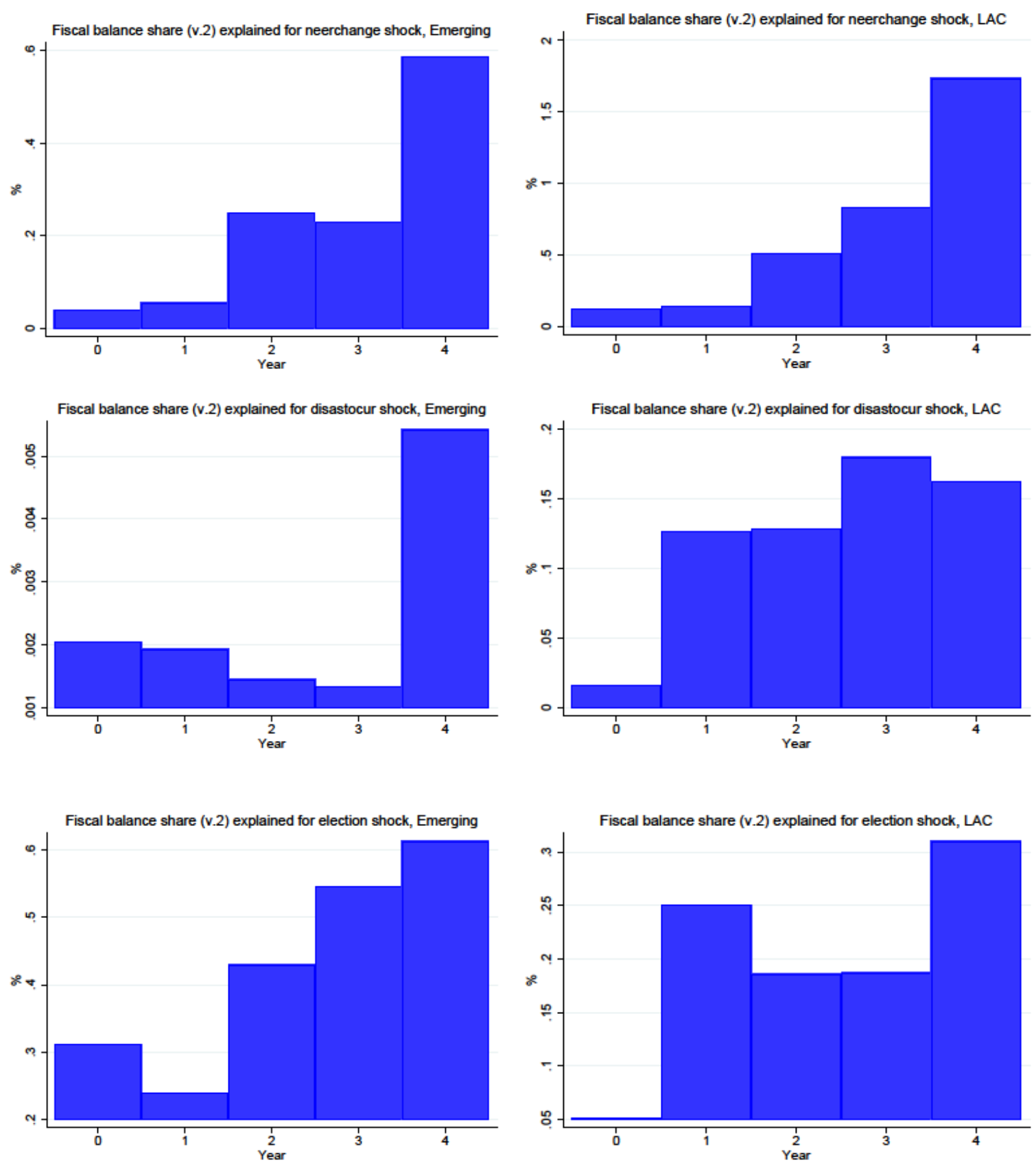

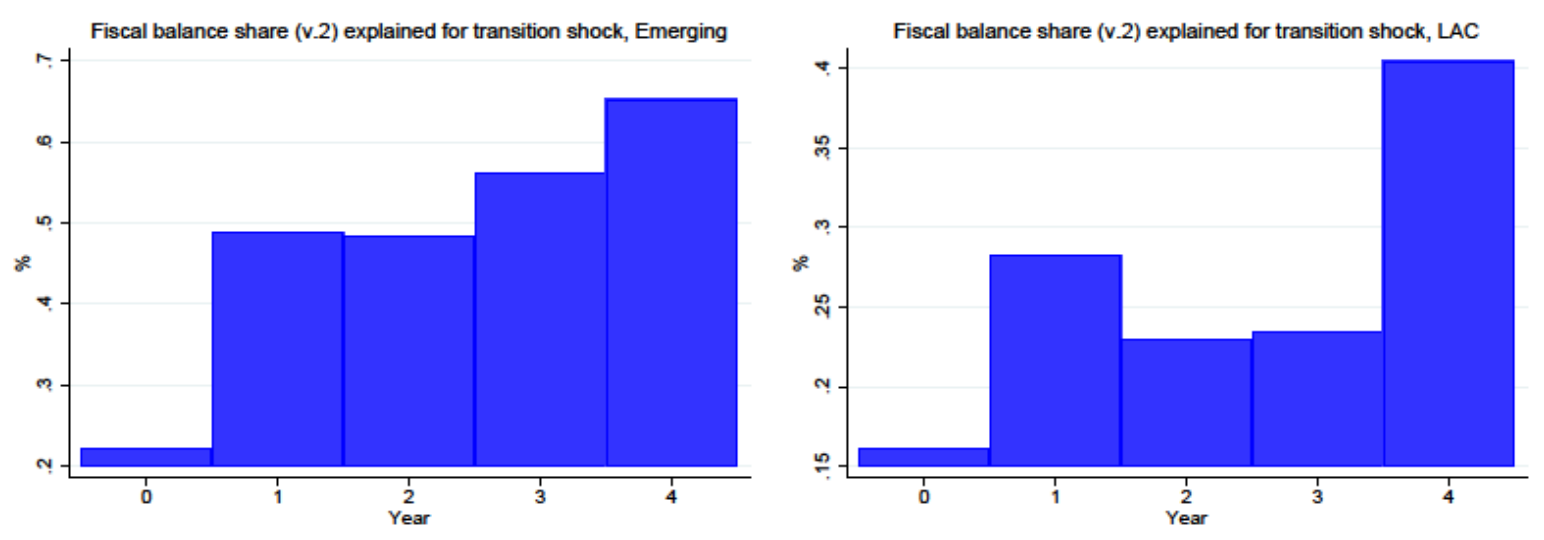

Expenditure and Revenue ratio contribution to the variance decomposition of the fiscal balance ratio

Note that percentages may not sum to one, since there is likely to be covariance between the two components; one may interpret them as the expected reduction in forecast error, at various horizons, if one were given the sequence of the unexpected shocks to one (but not both) of the two sub-components of the fiscal balance.
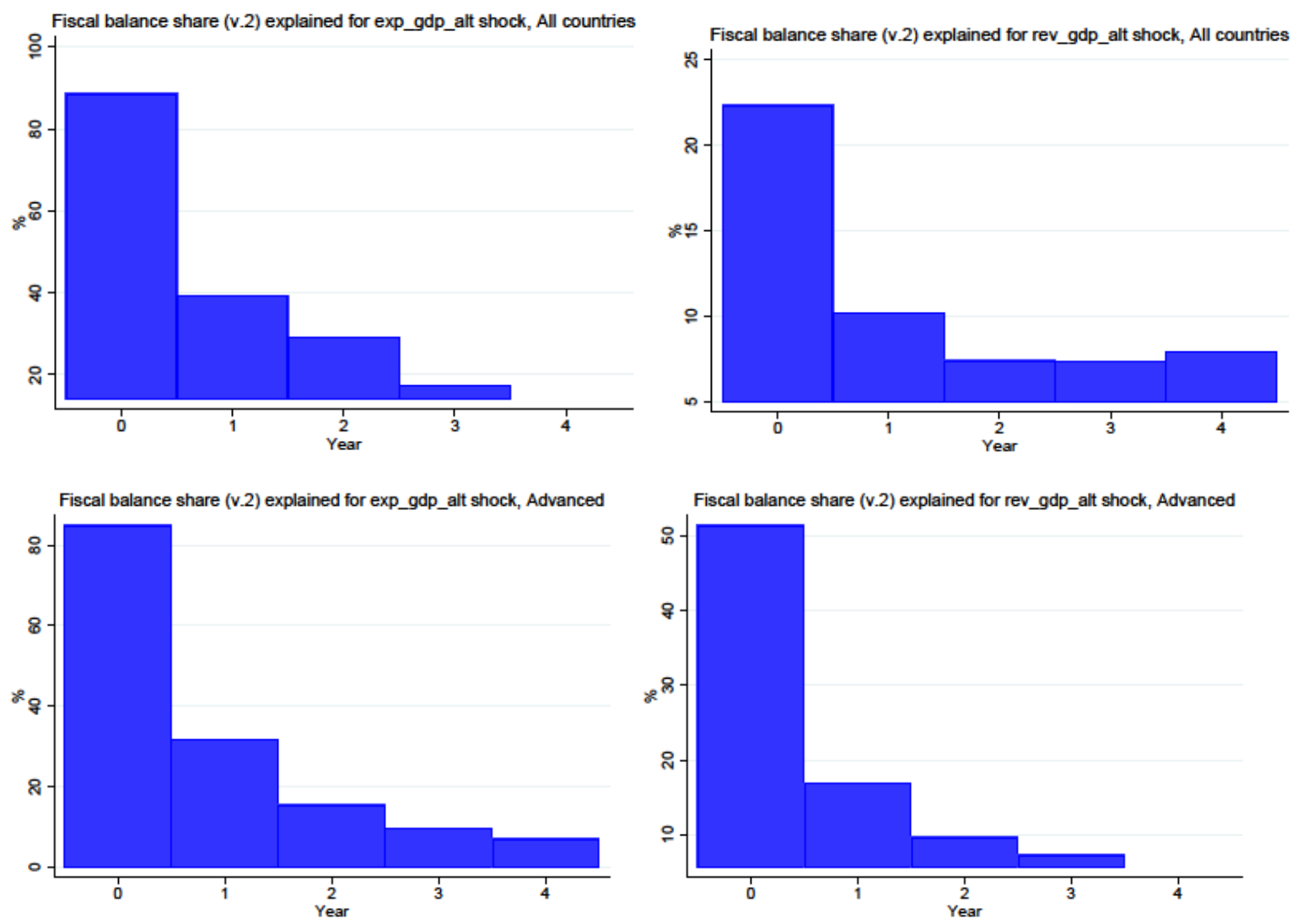

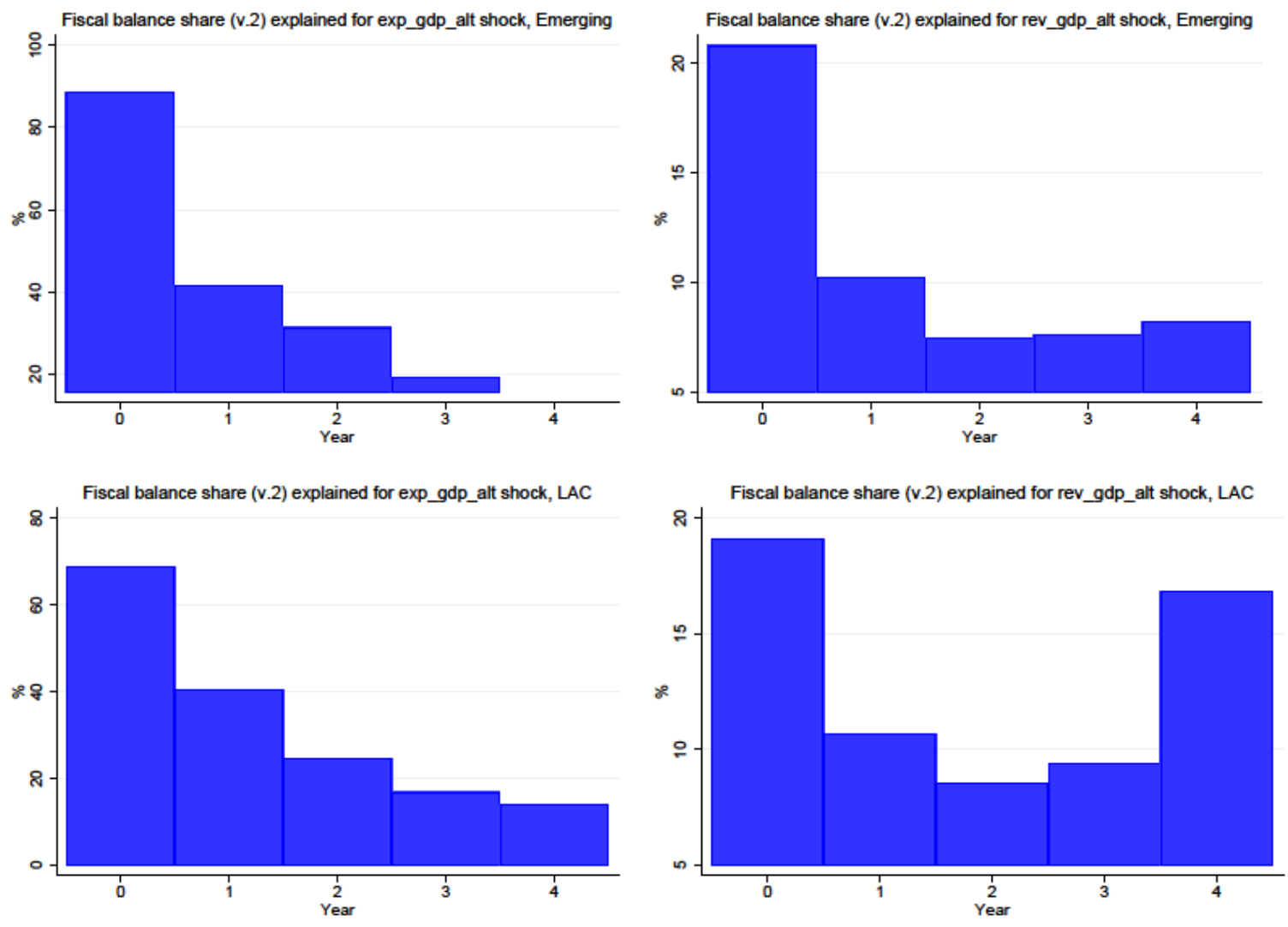